MAISA HELENA ALTARUGIO

\title{
A POSIÇÃO SUBJETIVA DO FORMADOR NA CONDUÇÃO DO PROCESSO REFLEXIVO DE PROFESSORES DE CIÊNCIAS
}

TESE DE DOUTORADO

UNIVERSIDADE DE SÃO PAULO

FACULDADE DE EDUCAÇÃO

SÃO PAULO

2007 
MAISA HELENA ALTARUGIO

\title{
A POSIÇÃO SUBJETIVA DO FORMADOR NA CONDUÇÃO DO PROCESSO REFLEXIVO DE PROFESSORES DE CIÊNCIAS
}

Tese apresentada ao Programa de PósGraduação em Educação, da Faculdade de Educação da Universidade de São Paulo, como requisito parcial à obtenção do título de Doutor em Ensino de Ciências e Matemática, sob a orientação do Prof. Dr. Alberto Villani.

\author{
UNIVERSIDADE DE SÃO PAULO \\ FACULDADE DE EDUCAÇÃO \\ SÃO PAULO \\ 2007
}


Já que estou hoje sendo arrastado pelas trilhas do inconsciente estruturado como uma linguagem saiba-se disto - esta fórmula muda totalmente a função do sujeito como existente. $O$ sujeito não é aquele que pensa. O sujeito é propriamente, aquele que engajamos, não, como dizemos a ele para encanta-lo, a dizer tudo - não se pode dizer tudo - mas a dizer besteiras, isso é tudo.

(...)

É com essas besteiras que vamos fazer a análise, e que entramos no novo sujeito que é o do inconsciente. É justamente na medida em que ele não quer mesmo mais pensar, o homenzinho, que se saberá talvez um pouco mais dele, que se tirará algumas conseqüências dos ditos - ditos que não podemos nos desdizer, é a regra do jogo.

Lacan, Seminário 2,1972-73 


\section{AGRADECIMENTOS}

Ao Prof. Alberto Villani e ao nosso grupo de pesquisa, com quem tenho aprendido lições preciosas de cooperação e incentivo nesta trajetória.

À Carmem Lúcia, analista, pela oportunidade de uma experiência que jamais alcançaria pelas páginas dos livros.

Ao Tom, meu marido, que com muito amor e paciência, soube bem compreender e suportar minhas ausências.

À Anna Maria, pelo interesse pessoal e disponibilidade para a revisão do texto.

Aos meus pais, mais uma vez, pelo apoio incondicional. 


\section{RESUMO}

Assim como o professor que ele pretende educar, o formador também traz consigo suas crenças, suas experiências pessoais e modelos que incorporou ao longo de sua própria formação e caminhada como profissional. Desse modo, o formador também é um sujeito que enfrenta dificuldades, que se submete a riscos, que se encontra dividido entre seus medos e seus desejos, submetido à sua inteligência e sua intuição e é vítima de seus contrastes.

Por isso, focalizamos nossa atenção no formador, investigando suas ações e questionamentos no interior dos cursos de formação continuada, especialmente no que se refere ao enfrentamento de seus impasses. Privilegiando os aspectos da subjetividade dos formadores, tentaremos compreender em que medida essas ações e questionamentos, explícita e implicitamente, podem influenciar a prática dos formadores e gerar impacto sobre os professores em formação.

No contexto das ações e questionamentos, exploramos os referenciais teóricos da reflexão-ação (D. Schön) e do professor reflexivo (K. Zeichner), cujas origens remontam ao pensamento reflexivo (J. Dewey). Uma vez que esses modelos teóricos, crescentemente valorizados no campo da formação continuada, não consideram que o plano inconsciente atua e intervém nos pensamentos e nas ações dos sujeitos, discutimos e ampliamos seus limites enquanto teoria e prática, à luz do referencial teórico da psicanálise.

S. Freud, J. Lacan e demais autores que acreditam na possibilidade de articular psicanálise e educação, serviram como suporte para as nossas análises. Em particular, exploramos principalmente os conceitos de transferência, Outro, gozo e desejo, analisando as posições subjetivas dos sujeitos pesquisados em relação a esses elementos, enquanto 'exercem a função de' ou 'assumem um lugar como' formadores de professores.

Neste trabalho, sustentamos a tese de que o questionamento das posições subjetivas dos sujeitos, por meio da prática de uma reflexão mais profunda e 
perturbadora, revele-se mais promissora para se alcançar mudanças satisfatórias na prática docente. Por fim, são sugeridas algumas pistas que podem auxiliar na construção de um novo formato para os cursos de formação.

Unitermos: formação de professores, psicanálise, subjetividade, ciências: estudo e ensino, professor reflexivo, prática reflexiva 


\begin{abstract}
Just like the teacher they intend to educate, a teacher educator also holds their beliefs, their personal experience and models, which they have acquired throughout their own education and professional development. Therefore, the educator is also someone who faces difficulties, who is subject to taking risks, who finds themselves at a crossroads, divided over their fears and wishes, victims of their contrasts, and submitted to their intelligence and intuition.

For this reason, we have turned our attention to the educator, studying their actions and queries along continuing education courses, mainly concerning the way they deal with their dilemmas. Focusing on the educators' subjective aspects, we are going to try to understand to what extent their actions and queries may, either explicitly or implicitly, influence the educators' practice and impact on the teachers being prepared.

As far as actions and queries are concerned, we have stuck to the theoretical references of the reflection-action (D. Schön) as well as to those of the reflexive professor (K. Zeichner), the origins of which are found in the reflexive thought (J. Dewey). Since these theoretical models, increasingly valued within the continuing education scope, do not take into consideration that the unconscious level works and interferes in people's thoughts and actions, we have discussed and widened their limits regarding theory and practice according to psychoanalysis theoretical reference.

S. Freud, J. Lacan and other authors who believe it is possible to articulate psychoanalysis and education provided the support for our analysis. We were mainly concerned with the concepts of transference, the Other, enjoyment and desire, analyzing the subjective attitude of the individuals studied in relation to these elements, as they "play the role" or "take over the position" of teacher educators.
\end{abstract}


In this study, we support the idea that questioning educators' subjective attitudes, through a deeper and disturbing reflection, may turn out to be more promising in the search for satisfactory changes in teaching practice. Finally, we provide some hints which may help pave the way for a new format for teacher education courses.

Key-words: teachers' education, psychoanalysis, subjectivity, sciences: study and education, refelexive professor, reflexive practice 


\section{SUMÁRIO}

Página

INTRODUÇÃO. .11

CAPÍTULO I

DO PENSAMENTO REFLEXIVO À PRÁtICA REFLEXIVA NA FORMAÇÃO DE PROFESSORES.................................................21

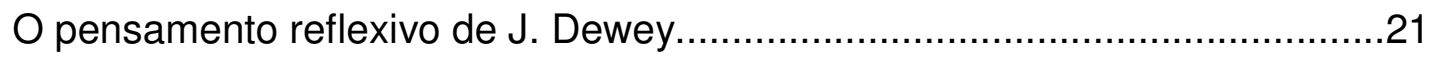

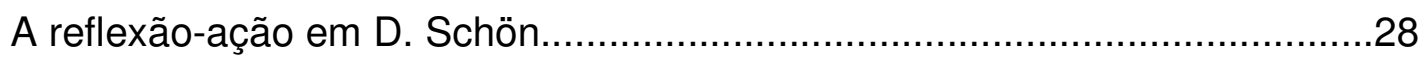

Para além de J. Dewey e D. Schön: a reflexão numa perspectiva psicanalítica 31

A prática reflexiva na formação de professores.............................................43

O papel do formador na formação de professores e do analista na análise: analogias possíveis

\section{CAPÍTULO II}

METODOLOGIA DA PESQUISA. 58

\section{CAPÍTULO III}

ANÁLISE DOS DADOS. 64

A experiência da pesquisadora no papel de formadora...............................64

A experiência da formadora Malu.............................................................111

A experiência do formador Nil...................................................................129

A experiência do formador Ronaldo.....................................................147

A experiência da formadora Jerusa.....................................................159 
CONSIDERAÇÕES FINAIS...........................................................

REFERÊNCIAS BIBLIOGRÁFICAS................................................182 


\section{INTRODUÇÃO}

Talvez exista uma expressão de desejoo de final de análise - que não passa pela demanda, quando não há mais para quem demandar, e que, como o ato poético, não pede passagem: expressase um desejo e não uma demanda. Momento em que a pessoa não pede, não solicita, mas se apropria, se diz, se impõe. O poeta como ninguém sabe expressar um desejo.(Forbes, 1999,VII)

Nesta introdução, tento reconstituir um pouco da trajetória que originou, evoluiu e culminou no trabalho de pesquisa que apresento aos nossos leitores. É uma trajetória que faz sentido, a partir das indagações resultantes da minha dissertação de mestrado "Este curso não se adapta à minha realidade: os conflitos de um grupo de professores de química em formação continuada" (Altarugio, 2002). Desses tempos anteriores, o que importa resgatar são os frutos que ela deixou e que continuam a gerar novas sementes para o solo ainda fértil dos meus interesses de pesquisa em educação.

Foi por ocasião daquele trabalho de investigação das dificuldades da docência, revelando o "sofrimento" dos professores em sua tarefa primordial, que pude compreender melhor a minha própria situação, pois partilhava com eles dos problemas e das queixas peculiares ao magistério. Os professores, em cujos relatos de práticas eu procurava entender as razões do mal-estar da profissão, serviramme como espelhos, refletindo imagens com os quais me identificava.

Aprendi com aqueles professores e com a Psicanálise, inicialmente com Freud, que, apesar das identificações, cada sujeito apresenta em sua história de vida uma singularidade, um modo diferente de ver o mundo, o outro e a si mesmo. Com isso, 
aprendi a diferença entre realidade concreta e realidade psíquica ${ }^{1}$ e como a confusão entre uma e outra, quando tomadas como sendo a mesma coisa, pode gerar o mal-estar docente.

A análise dos depoimentos dos professores a respeito do modelo de capacitação a que foram submetidos, trouxe resultados surpreendentes em relação ao modo deles se posicionarem frente à realidade concreta encontrada nas escolas, fruto de suas realidades psíquicas. Pude perceber que as dificuldades dos professores em atuar na sala de aula e manejar as variáveis complexas que envolvem a docência, vão além daquelas que eles e os formadores conseguem captar conscientemente.

No campo da subjetividade, encontrei terreno fértil para discutir as vicissitudes da tarefa de educar. Discutir a subjetividade nas ações dos sujeitos, a partir da psicanálise, significava penetrar mais fundo numa dimensão que, ainda hoje, poucos pesquisadores - anseio que essa proporção aumente - ousam admitir ou considerar: a do inconsciente.

Percebi na prática como é fascinante o modo de pensar e de agir de cada professor, porque a psicanálise me ensinou sua principal lição: o que importa é o sujeito.

Aprender, observando e questionando profundamente os modos de pensar dos professores, me trouxe demonstrações indubitáveis quanto ao potencial do referencial teórico da psicanálise para a análise das questões da educação. Engana-se quem ainda pensa estar a psicanálise restrita ao divã. A Psicanálise, hoje, ganhou o mundo, as instituições, os hospitais, as escolas.

A experiência dos professores e o estudo da psicanálise me abriram possibilidades para que eu levasse meus questionamentos para além dos territórios que estava habituada a percorrer: o da lógica consciente, da cognição, das certezas. Não sem angústias, não sem resistências e não sem deslizes, reconheço

\footnotetext{
${ }^{1}$ Os termos grafados em itálico encontrados nesta Introdução se referem a conceitos do referencial teórico da Psicanálise em S. Freud e J. Lacan, posteriormente esclarecidos no Capítulo I e discutidos ao longo deste trabalho.
} 
que me tornei uma profissional (e por que não dizer também, uma pessoa) em melhores condições de lidar com o "impossível" da minha tarefa.

Se aprendi algumas lições, ou se o saber da psicanálise encontrou um campo onde pôde operar, é porque em mim já havia o desejo.

\begin{abstract}
...ao demandar o saber da psicanálise, o educador já está formulando uma demanda, já supõe naquele corpo teórico um saber sobre o seu desejo. Deste lugar, ouvirá o que uma teoria - que como toda teoria, recalca o sujeito - tem a dizer. Extrairá dali as respostas que lhe aprouverem, fará enganchar em seu desejo as "respostas" da psicanálise, procederá ao esvaziamento do conteúdo semântico das palavras de seu professor-psicanalista e colocará ali, transferirá para ali, o sentido ditado por seu desejo.(Kupfer,2000, p.118)
\end{abstract}

Se houve para mim um aprendizado tão útil nesta trajetória, proporcionado pela análise das experiências singulares de outros professores e a partir do saber da psicanálise, por que esses professores não poderiam também aprender algo a partir das minhas conclusões? Como poderia lhes dar a oportunidade de desfrutar daquilo que vim a descobrir sobre seus modos de ver o mundo, o outro e a si mesmos?

É para tentar sair de mais uma demanda - que é um puro "querer" uma resposta do Outro (da Psicanálise, da Academia e do meu orientador) - e assumir o desejo - que envolve construir um saber singular e criativo para um enigma da existência, que por ser um motor vital, não cessa (e nem pode cessar) de aparecer que prossigo minhas investigações nesta atual pesquisa.

\title{
Da demanda ao desejo
}

O desejo de buscar respostas para essas questões passou a animar minha existência como pesquisadora, embora na composição desse trabalho - como uma autêntica neurótica frente a uma "caixinha de surpresas" - não possa negar uma boa dose de demanda de amor, o que equivale em termos lacanianos a se perguntar "O que o Outro quer de mim?".

Mas como diante de mim o Outro se calou - assim como se cala o analista diante do analisando, pois só dizendo não a sua demanda é possível fazer emergir 
dele o desejo - só me restou ter que assumir a responsabilidade pelo meu desejo, enquanto tentava suportar não ter minhas demandas respondidas.

Comecei resgatando, através da leitura de algumas pesquisas e documentos oficiais que legislam sobre a educação, e de relatos de professores em formação continuada, material sobre o qual pudesse refletir mais profundamente a respeito das exigências em relação aos conhecimentos teóricos e práticos desejáveis aos professores no exercício de sua função.

Essas exigências não são poucas e podemos destacar aqui algumas delas citadas por Sánchez e Valcárcel (2000) em consenso com outros pesquisadores (Brincones et al.,1986; Sáez, 1990; Gil, 1991, Furió, 1994; Pórlan et al., 1996; Duschl, 1997 e muitos outros), tais como: conhecer em profundidade a sua disciplina; saber detectar, analisar e interpretar as concepções prévias dos alunos sobre os conteúdos abordados; conhecer a psicologia e a sociologia do adolescente; ter critérios para seleção e seqüenciação de conteúdos.

No texto dos PCNEM (Parâmetros Curriculares Nacionais do Ensino Médio), encontramos, além de uma extensa descrição dos saberes e competências exclusivas do domínio dos docentes das áreas específicas, uma noção do mestre (ideal) que deve protagonizar a educação dos nossos jovens, ou seja, aquele que se "aproprie não só dos princípios legais, políticos, filosóficos e pedagógicos que fundamentam o currículo proposto, e que se mantenha convicto da importância e da possibilidade de seu aprendizado por todos seus alunos" (PCNEM, 1998).

Para dar conta desses conhecimentos teóricos e práticos desejáveis aos professores, vários modelos de formação continuada têm sido praticados. Copello e Sanmartí (2001) organizam esses modelos segundo duas tipologias: aqueles que se caracterizam por tratarem de temas específicos, cuja integração ao espaço de atuação fica por conta de cada professor e aqueles cuja finalidade é transformar as práticas dos professores. Esses últimos geralmente ocorrem nos próprios locais de trabalho e tentam promover a reflexão epistemológica e psicopedagógica, relacionando-a com a área específica do conhecimento.

A esses modelos de formação, acrescenta-se uma preocupação, mais recente, com o desenvolvimento do profissional crítico e reflexivo (Schön, 1992; Perrenoud, 
1993; Zeichner, 1995), que incorpora habilidades do tipo metacognitivo (Gunstone e Northfield, 1994).

Por outro lado, também são bem conhecidas dos pesquisadores, as dificuldades dos professores em realizar mudanças efetivas em suas práticas. Tentando explicar as razões do lento processo de mudança nas práticas de ensino, Copello e Sanmartí, por exemplo, mencionam a desarmonia entre o interesse das administrações públicas em mostrar resultados imediatos, que primam pela quantidade ao invés de qualidade, e o fato da formação dos professores exigir tempo e se efetivar a longo prazo.

Outros exemplos da natureza dessas dificuldades, foram relatados pelos professores de ciências num curso de formação continuada e apontados em minha pesquisa de mestrado. Fatores externos ao professor tais como: ausência de laboratórios ou equipamentos adequados nas escolas, alunos desinteressados e indisciplinados, falta de apoio dos colegas e da direção da escola, número insuficiente de aulas, salas de aulas muito lotadas; acrescidos de fatores internos como: a dificuldade de abandonar os vícios do ensino tradicional e a insegurança diante das novas propostas, ainda se configuram obstáculos trazidos para o interior dos cursos de formação continuada.

Mas todo esse saber a respeito dessas competências teóricas e práticas, e sobre a natureza dos obstáculos que os professores enfrentam no seu cotidiano, parece que não tem sido suficiente para explicar a atual situação do ensino nas escolas e, principalmente, o mal-estar docente.

Pensando nas propostas atuais para a formação continuada, no mal-estar docente frente aos desafios da sua prática e animada pelo desejo de encontrar respostas para as questões primeiramente enunciadas, começava a se delinear para mim uma nova pergunta: como seria uma formação de professores que os levasse ao exercício - incomum nesse contexto - de um questionamento mais profundo a respeito de sua prática sob uma ótica em que pesasse o inconsciente? 


\section{Do desejo ao ato}

Para investigar essa possibilidade, aceitei o convite para participar, inicialmente como pesquisadora, num curso de formação continuada para professores de química, numa Universidade pública, em 2004. Minha intenção era ouvi-los, observando especialmente seus modos particulares de enfrentar os impasses diante das tarefas do curso, que envolviam ações e reflexões sobre a própria prática.

O curso foi conduzido por uma mestranda iniciante nessa tarefa e que, no momento oportuno, me deu a chance de protagonizar alguns dos encontros com o grupo de professores. Essa foi a oportunidade para colocar em prática uma estratégia com elementos análogos aos da técnica analítica - a associação livre, a escuta flutuante e as intervenções interpretativas - como forma de trazer à tona e trabalhar os elementos subjetivos implícitos nas ações dos professores. Também foi a ocasião em que descobri as sensações de estar no lugar de um formador e as dificuldades de enfrentar os impasses dessa tarefa.

Um conjunto de expectativas, inseguranças, angústias, questionamentos e satisfações, envolvidos nas ações antes, durante e depois dessa experiência, despertou-me para a responsabilidade do lugar que havia assumido. Em outras palavras, esses elementos da subjetividade de qualquer formador, atuando de forma inconsciente em sua prática, me pareceram fatores importantes para se levar em conta, quando se trata dos efeitos que podem ser gerados nos professores em formação.

Esse momento foi decisivo e culminou com a mudança radical na escolha do sujeito da pesquisa: decidi que o alvo não mais seria o professor, mas o formador de professores.

Assim como o professor que ele pretende educar, o formador também traz consigo suas crenças, suas experiências pessoais e modelos que incorporou ao longo de sua própria formação e caminhada como profissional. Esse formador, também é um sujeito que enfrenta dificuldades, se submete a riscos, se encontra dividido, age com sua inteligência e intuição, age com seus medos e desejos e é 
vítima dos seus contrastes. É um sujeito que é produto da interação complexa entre cognição e subjetividade, consciente e inconsciente.

Por esse motivo, os primeiros dados analisados são relativos à minha própria experiência nos momentos em que assumi o lugar de formadora. Não se tratou somente de analisar a minha prática, com interesse em discutir a metodologia e as estratégias aplicadas, mas de uma investigação desses elementos subjetivos que fazem parte do meu modo de ver e me relacionar com o mundo, com o outro e comigo mesma. E isso implicou não só num ato de coragem de me expor, mas um desejo de saber de si, de saber sobre o sujeito por detrás da prática.

Tendo uma clareza maior sobre a natureza do objeto e do sujeito da minha pesquisa, em 2005 estava preparada para conhecer a experiência de outros formadores. No meu contato com os formadores Malu, Nil e Ronaldo - todos eles professores com alguma bagagem no magistério, pesquisadores em estágio de mestrado ou doutorado na área de educação, iniciantes ou com pouca experiência na formação de professores - pude notar alguns contrastes interessantes entre as ações que eles praticavam e as reflexões que eles realizavam a partir delas. Também parecia haver uma oscilação muito grande nos estados de satisfação pessoal com a prática. Todo esse material trazia a promessa de uma análise frutífera em termos do que poderia ser revelado numa investigação sobre o papel da subjetividade do formador nos cursos de formação.

Mas ao conhecer as experiências da formadora Jerusa, que realiza trabalhos em formação continuada há longa data, surpreendeu-me a segurança e a aparente ausência de conflitos em seus relatos de prática, além do alto e permanente estado de satisfação e sucesso alcançados com seu trabalho. Isso significou estar diante de um dado novo: enquanto as ações e reflexões dos formadores iniciantes revelavam contrastes, como explicar a aparente ausência de conflitos no caso da formadora experiente? Que elementos da subjetividade dessa formadora estariam interferindo nas posições assumidas em seu trabalho e nos resultados da sua prática? E mais: que elementos da subjetividade desses formadores distinguiriam o grupo dos menos experientes e dos mais experientes? 


\title{
Procurando novos paradigmas
}

Nesta pesquisa, além de observar os formadores no exercício de seus papéis, irei colocá-los na posição de sujeito, sujeito falante. A teoria da comunicação, que sustenta a linguagem como veículo portador de uma mensagem entre emissor e receptor, não será suficiente para explorar as falas dos sujeitos, principalmente quando se pretende ir além do que elas literalmente comunicam. Isso porque a comunicação é um efeito da linguagem (Cabral, 1996) e como tal, ela não é direta, e isto é sabido "por aquilo que nos é devolvido quando falamos e que não é exatamente o que queríamos ouvir".

Assim é também para Smolka:

\begin{abstract}
A linguagem nem sempre comunica, não é transparente, ela significa através do "não dito" e não necessariamente através do que é dito. Admite a pluralidade de sentidos e significados, é polissêmica. A linguagem é fonte de equívocos, ilusões, mal-entendidos. Podemos dizer que ela "trabalha" ou "funciona" às vezes "por si", produzindo múltiplos efeitos, independentemente das intenções de quem fala; ela escapa ao conhecimento, poder e controle do homem. (Smolka apud Machado \& Moura,1995)
\end{abstract}

Quando os formadores falam nesta pesquisa, embora possam querer controlar a significação do que dizem, isso Ihes é, estruturalmente, impossível. A fala é atravessada pelo inconsciente, que funciona com sua lógica e suas leis próprias, por isso foge ao nosso controle. As falas dos formadores, independentes dos seus conteúdos, determinam sujeitos ocupando posições subjetivas e portanto, revelando contextos complexos. E é no interior dessa complexidade que está situado esse trabalho, de modo que a fala interessante é:

A fala fundamental, que é então inconsciente, é o elemento dinâmico essencial. (...) A descoberta do inconsciente, tal como ele se mostra, no momento do seu surgimento histórico, com sua dimensão plena, é que o alcance do sentido ultrapassa infinitamente os sinais manipulados pelo indivíduo. Sinais, o homem solta sempre muito mais do que ele pensa. É disto que se trata na descoberta freudiana - de uma nova impressão de homem. O homem, depois de Freud, é isso.(Lacan,1985, p.158) 
De acordo com o quadro de argumentos exposto e as questões levantadas ao longo, esse trabalho se propõe a:

- analisar experiências e relatos de formadores de professores, tentando buscar elementos subjetivos implícitos nas suas ações e reflexões;

- discutir como esses elementos subjetivos, que contemplam a existência e a interferência do plano inconsciente, podem influenciar a prática dos formadores e gerar impacto sobre os professores em formação;

- discutir e ampliar os limites da teoria da reflexão-ação como estratégia na formação de professores, sustentando a hipótese de que o questionamento das posições subjetivas dos sujeitos, revele-se mais promissora para se alcançar mudanças satisfatórias na prática docente. Nesse trajeto, são sugeridas algumas pistas que podem auxiliar na construção de um novo formato para os cursos de formação.

$\mathrm{Na}$ apresentação do trabalho, o primeiro capítulo resgata as origens do pensamento reflexivo em J. Dewey, explorando os pontos mais importantes da sua principal obra How We Think (1910), em português Como Pensamos (1933/1959). Logo após, apresento os principais pontos da teoria da reflexão-ação de Schön, em cuja obra Formar Professores como Profissionais Reflexivos (1992), se faz sentir a influência do pensamento pedagógico de J. Dewey. Ao entender que as teorias e técnicas de solução de problemas que os professores aprendem por conta do modelo de formação a que são submetidos nas universidades, são insuficientes para enfrentarem criativamente as situações complexas das práticas reais, Schön propõe buscar uma nova epistemologia da prática profissional.

Entretanto, se ocorre que a teoria da reflexão-ação - acolhida no seio da educação e crescentemente valorizada como estratégia no campo da formação continuada de professores - não considera que o plano inconsciente atua e intervém nos pensamentos e nas ações dos sujeitos, serão reconhecidos e apontados seus limites. Por meio de uma releitura de Dewey e Schön, à luz do referencial teórico da psicanálise em S.Freud e J.Lacan, e utilizando alguns de seus conceitos primordiais 
- transferência, Outro, outro, gozo, desejo - alarga-se a idéia de reflexão, tomando-a como uma prática de questionamento das posições subjetivas dos sujeitos frente às situações que se lhe apresentam.

Depois, serão apresentadas e discutidas algumas pesquisas recentes, cujos autores têm experimentado uma prática reflexiva nos moldes propostos por Schön, e outras que ampliam sua abordagem introduzindo componentes subjetivos a serem considerados no ato reflexivo. Em seguida, é destacado o papel do formador em analogia ao papel do analista - salvaguardando as especificidades de cada um explorando as possibilidades de uma aproximação de suas práticas, na perspectiva de apoiar essa idéia e sugeri-la como uma nova forma de pensar a formação de professores.

O segundo capítulo trata da metodologia da pesquisa, desde a escolha dos casos, passando pelos procedimentos de coleta e registro dos dados, até os critérios de análise dos mesmos. Também é destacado o papel do grupo de pesquisa em psicanálise e ensino de ciências, na construção e efetivação da presente metodologia.

No terceiro capítulo, serão apresentados os casos de cinco formadores, primeiramente, descrevendo de forma objetiva os eventos colhidos por meio da observação das experiências e/ou dos relatos das práticas. A experiência da pesquisadora, que inicia o estudo dos casos, representa um estudo, embora singular, mais completo e aprofundado em termos de percepções e memória que os demais, visto que a pesquisadora dá testemunho próprio de sua prática. Uma particularidade dessa análise e da análise dos outros casos, é o uso que a pesquisadora faz do outro como espelhos refletores da sua própria imagem. As identificações com as imagens do outro, a medida em que elas aparecem, em vários momentos das análises, permitem que a cada vez, sejam reveladas as suas posições subjetivas. Os casos dos outros formadores vêm acrescentar novos elementos para a reflexão dos leitores.

Por último, no quarto capítulo, seguirão as considerações finais, nas quais serão retomados os objetivos e hipóteses iniciais dessa pesquisa, apontando as conclusões e perspectivas que animam a continuação de novos trabalhos. 


\title{
CAPÍTULO I
}

\section{DO PENSAMENTO REFLEXIVO À PRÁTICA REFLEXIVA NA FORMAÇÃO DE PROFESSORES}

\author{
Pensar é lutar e dominar aquilo que, \\ do inconsciente, resiste à objetivação. \\ São imagens e fantasias que jorram \\ desse lugar psíquico, encharcando as \\ produções da razão.(Bacha,2002)
}

\section{O PENSAMENTO REFLEXIVO DE J. DEWEY}

A teoria da reflexão-ação de Schon - comumente referida e conhecida no meio educacional - e suas implicações no campo da formação de professores, como ele próprio diz, "não tem nada de novo". Suas idéias podem ser encontradas nas obras de Leon Tolstoi, John Dewey, Lev Vigotsky, Jean Piaget e outros. Entre esses, foi o filósofo americano John Dewey quem fez a maior aproximação entre as idéias sobre as diferentes formas de pensar e seus reflexos na educação.

Em oposição ao modelo de educação de sua época, que privilegiava a obediência e a submissão ao professor em detrimento da iniciativa e da autonomia, Dewey entendia que a escola devia preparar os alunos para a resolução de problemas reais, cotidianos.

O ensino corre sempre o risco de afogar a experiência vital, conquanto limitada, do discípulo, num acúmulo de noções transmitidas. Aquele que não é mais que um instrutor acaba onde começa o verdadeiro professor: 
no ponto em que a matéria transmitida incute, em tudo que entrara pela exígua, estreita porta da percepção sensorial e da atividade motora, uma vida mais completa e significativa. (Dewey, 1959,p.287)

Assim, Dewey funda em 1896 a Escola Laboratório de Chicago, conciliando conhecimentos da filosofia e da psicologia a um programa pedagógico aberto. Nessa escola, a aprendizagem da leitura, da escrita e do cálculo funcionava mais como um instrumento - cuja aplicação estava voltada para questões cotidianas que solicitavam resolução - do que como um fim.

Sua obra How We Think (1910), em português Como Pensamos (1933/1959), foi o marco da corrente "instrumentalista" aplicada à educação. Esta corrente caracteriza-se por imprimir valor instrumental do conhecimento e do pensamento na resolução de situações problemáticas concretas do cotidiano. Dada a expressão desta obra, propomos discuti-la em seus pontos principais e traçar uma linha de evolução que se origina no pensamento reflexivo de J. Dewey, passando pelo modelo do professor reflexivo em D. Schön, ampliado por K. Zeichner, até os autores que o admitem sob outras perspectivas. Dentre elas as que mais nos interessam vão em direção ao nosso referencial teórico, a Psicanálise.

Neste trajeto, nossa idéia é aprofundar a noção de pensamento reflexivo, ampliar a discussão sobre a prática reflexiva, sobretudo sua aplicação na formação de professores e ao mesmo tempo, introduzir conceitos da psicanálise que, em nossa concepção, vão servir para alargar as idéias originais e abrir novas possibilidades para a tarefa de formar educadores.

\section{Sobre os sentidos do pensamento}

Dewey nos apresenta em Como Pensamos (1959) - do qual nos serviremos de vários trechos - três processos mentais que comumente recebem o nome de pensamento, mas fazendo questão de esclarecer que "a melhor maneira de pensar, a ser considerada nesta obra, é chamada de pensamento reflexivo: a espécie de pensamento que consiste em examinar mentalmente $o$ assunto e dar-lhe consideração séria e consecutiva".

O primeiro desses processos Dewey denomina "corrente da consciência": 


\begin{abstract}
"Pensar" chama-se, às vezes, a esse curso desordenado de idéias que nos passam pela cabeça, automática e desregradamente. (...) O estado de vigília se nos decorre, mais do que admitiríamos, nessa inconseqüente frivolidade de fantasias mentais, fortuitas lembranças, esperanças gratas mas infundadas, impressões vagas e incompletas. Por isso, quem oferece "um níquel pelos seus pensamentos" não fará grande negócio se a oferta for aceita; obterá apenas o que está passando pela cabeça do outro. E o que passa desse modo raramente tem valor. (ibid. p.14)
\end{abstract}

Dewey apresenta a razão pela qual esse processo não pode ser tomado como pensamento reflexivo:

...ñ̃o basta a mera sucessão irregular "disto ou daquilo". A reflexão não é simplesmente uma seqüência, mas uma conseqüência - uma ordem de tal modo consecutiva que cada idéia engendra a seguinte como seu efeito natural e, ao mesmo tempo apóia-se na antecessora ou a esta se refere. (...) A correnteza, o fluxo, transforma-se numa série, numa cadeia. Em qualquer pensamento reflexivo, há unidades definidas, ligadas entre si de tal arte que o resultado é um movimento continuado para um fim comum. (ibid. p.14)

O segundo processo mental refere-se ao ato de pensar aplicado "a coisas não sentidas ou diretamente percebidas pelos sentidos, a coisas que não são vistas, ouvidas, tocadas, cheiradas, nem provadas.(...) Não vi; mas penso que assim se sucedeu". É o caso, por exemplo, das histórias contadas pelas crianças que, embora conectadas com coerência lógica, permanecem no nível das elaborações imaginárias, das representações mentais de algo não realmente presente. Para Dewey, esse pensar é simples diversão, sem o propósito de aplicar o pensamento mediante algo a ser esclarecido aspirando a uma conclusão.

O terceiro processo mental corresponde ao "pensamento como sinônimo de crença".

"Acredito que a Terra é redonda". (...) É uma idéia que colheu de outros e que aceita por ser corrente, não por tê-la examinado, não por ter tomado parte ativa na sua conquista e elaboração. (...)É desnecessário acentuar a importância da crença. Abrange todas as matérias de que não temos conhecimento seguro, mas em que confiamos o bastante para nelas basear a nossa ação; e, igualmente as matérias aceitas como verdadeiras, como conhecimento, suscetiveis, todavia, de futuras indagações. (...). Tais "pensamentos" são preconceitos; isto é, prejuízos, não conclusões alcançadas como resultado da atividade mental pessoal, observação, coleta e exame de provas. (ibid. p.16) 
Embora as crenças não sejam resultados de um pensar reflexivo, Dewey admite serem elas passíveis e merecedoras de reflexão nas bases propostas, pois "envolvem precisamente essa realização intelectual e prática; e por conseguinte, cedo ou tarde, requerem investigação a fim de se descobrirem as bases em que repousam".

\section{Sobre a finalidade do ato de pensar reflexivo}

Dewey resume no parágrafo transcrito abaixo a principal finalidade do pensamento reflexivo:

A função do pensamento reflexivo é, por conseguinte, transformar uma situação de obscuridade, dúvida, conflito, distúrbio de algum gênero, numa situação clara, coerente, assentada, harmoniosa. (...) Não há melhor modo de se saber se se realizou uma genuína inferência do que perguntar se terminou pela substituição de uma situação embaraçosa, discordante, por uma situação clara, ordenada, satisfatória. (ibid. p.105)

Para Dewey, o pensamento reflexivo tem importância educacional, pois embute em si mesmo valores que distinguem o homem dos animais e o homem civilizado do selvagem. Em primeiro lugar, o ato de pensar possibilita a ação de finalidade consciente pois o pensar "é uma capacidade que nos emancipa da ação unicamente impulsiva e rotineira; converte uma ação puramente apetitiva, cega e impulsiva, em ação inteligente".

Um outro valor agregado ao ato de pensar reflexivo, estaria no sentido ampliado e enriquecido que ganhariam os objetos e fenômenos, sentido esse que seria muito diferente para alguém que não reflete. Por exemplo, "para um leigo, um volume de água significa, provavelmente, coisa com que se lava ou que se bebe; para outra pessoa, constituirá uma união de dois elementos, não líquidos, mas gasosos; ou significará coisa que não deve ser ingerida, pelo perigo de tifo". 


\title{
Sobre o pensamento equivocado e as atitudes do pensar
}

\author{
Dewey se apóia no pensamento de Locke $^{2}$ para mostrar várias maneiras pelas \\ quais se equivoca o pensamento. A transcrição de duas delas nos parece \\ interessante destacar:
}

A primeira categoria é a daqueles que raras vezes raciocinam, pensando e procedendo consoante o exemplo dos demais, sejam os pais, os vizinhos, os ministros de sua religião ou quem quer que lhes agrade, escolher como objeto de fé implícita, para forrar-se ao esforço e ao aborrecimento de pessoalmente refletir e examinar.(Locke apud Dewey, p.35)

Essa primeira categoria inclui os indivíduos que aparentemente são desprovidos de opinião própria, deixando-se levar pela influência de outras pessoas de seu relacionamento próximo ou do grupo de convívio. Sendo assim, elas se

\footnotetext{
${ }^{2}$ John Locke (1632-1704), filósofo inglês fundador do empirismo crítico, demonstrou seu interesse em três áreas do conhecimento: a) o gnosiológico, do qual brotou sua principal obra o Ensaio sobre o intelecto humano (1690), b) o ético-político, que encontrou expressão (além de sua própria militância política prática) nos escritos dedicados a esse tema; c) o religioso, campo no qual a atenção do nosso filósofo se concentrou sobretudo nos últimos anos de sua vida. A esses podemos acrescentar, mas numa dimensão menor, um quarto interesse, de caráter pedagógico, que encontrou expressão nos Pensamentos sobre a educação (1693).
}

F. Copleston, historiador inglês da filosofia, foi quem apresentou um juízo de conjunto mais comedido e convincente sobre Locke: "Como fica claro em seus escritos, Locke foi homem muito moderado. Empirista, quando afirma que todo o material do nosso conhecimento é fornecido pela percepção sensível e pela reflexão, mas não empirista (ou seja, empirista não extremista), quando não pensa que nós só conhecemos as coisas percebidas através dos sentidos. De forma elementar, ele é (... também) racionalista, porque está certo do primado do juízo racional sobre todas as opiniões e crenças e porque desaprova a substituição de expressões emocionais e sentimentos em lugar de juízos fundados na razão. Mas não é racionalista no sentido de desprezar a realidade espiritual, a ordem sobrenatural ou a possibilidade de revelação divina da verdade, que, embora não estejam em contraste com a razão, estão contudo acima dela, não podendo ser descobertas somente pela razão e também não podendo ser plenamente entendidas mesmo quando são reveladas".

Dewey converge em Locke pela aposta numa educação pela razão. Dewey considera que existe um "inconsciente influxo do ambiente" que exerce função educativa casual, como na formação de hábitos de linguagem e de apreciação de valores estéticos. Esses hábitos devem "ser corrigidos, ou mesmo suprimidos pelo ensino consciente", podendo dar-se o mesmo com as idéias que assumimos no transcurso de nossa vida, no contato esporádico e não planejado com outras pessoas. É sobre tais influências "inconscientes", casuais e negativas, que a escola deve atuar, selecionando-as e afastandoas do ambiente educacional, o que mostra a relevância conferida por Dewey ao estabelecimento de fins educacionais situados em plano superior ao da experiência informal. 
furtariam de uma reflexão, por suporem que os outros detêm um saber confiável ou simplesmente por acomodação ou preguiça.

Mais adiante, Locke justifica essa categoria de uma forma mais complacente com o sujeito, tirando-lhe, de certa forma, a responsabilidade consciente pelo que Ihe acontece:

\begin{abstract}
Pois, chegados à idade adulta, ao refletirem sobre suas opiniões e ao notarem que as da espécie acima (pais, amas ou outras pessoas com quem se achem em contato) são tão antigas, em seu espírito, como as próprias suas recordações, e não havendo observado nem a prematura penetração, nem a origem dessas idéias, os homens propendem a venerálas como se fossem sagradas e a não suportar que sejam profanadas, tocadas ou discutidas.( Locke apud Dewey, p.36)
\end{abstract}

A segunda categoria inclui a "espécie dos que põem a paixão no lugar da razão e, achando-se resolvidos a dirigir seus atos e argumentos, não usam sua própria razão nem atendem à dos outros, sempre que não se adapte à sua disposição de espírito, a seu interesse e ao seu partido".

Está claro que os argumentos que Dewey busca em Locke, são para reforçar que o pensar reflexivo, em sua concepção, não admite a interferência de interesses individuais ou de grupos, bem como de componentes subjetivos (tais como a paixão), que tomariam a frente da razão, por onde teoricamente deve se guiar o pensamento reflexivo.

\title{
Sobre as atitudes pessoais para o pensar reflexivo
}

Dewey admite que o fato de uma pessoa ter habilidades lógicas de pensamento, não significa que isso seja suficiente para que ela as adote em quaisquer situações.

Igualmente, é bastante duvidoso que a prática de pensar segundo certa fórmula lógica resulte na aquisição de um hábito geral de pensamento, isto é, um hábito aplicável a uma extensa linha de assuntos. É de fato muito conhecido que homens que se provam experimentados pensadores no seu campo de trabalho adotam, em outras matérias, pontos de vista inteiramente desapoiados da investigação que eles sabem indispensável para a concretização de fatos mais simples, dentro de sua própria especialidade. (ibid. p.38) 
O autor admite - porém, sem explicar as razões - que um certo comportamento se apresente para um indivíduo: uma disposição para o raciocínio lógico em certo campo de sua atividade não garantiria sua aplicabilidade em outro. No entanto, Dewey sugere que o indivíduo cultive certas atitudes que favoreceriam o pensar reflexivo:

a) espírito aberto. Essa atitude poderia ser definida como independência de preconceitos, de partidarismo e de outros hábitos como o de cerrar a mente e indispô-la à consideração de novos problemas e novas idéias.

b) de todo o coração. Não haveria maior inimigo do pensamento eficiente que o interesse dividido.

c) responsabilidade. É comum ver-se pessoas continuarem a aceitar crenças cujas conseqüências lógicas recusam reconhecer. Professam-nas, mas não querendo admitir os seus efeitos. O resultado seria a confusão mental. Levar alguma coisa ao completamento seria o sentido real da perfeição e essa capacidade dependeria da responsabilidade intelectual.

Ao destacar essas três atitudes, Dewey considera importante aliar aspectos subjetivos do indivíduo à compreensão das formas e técnicas, para assegurar a adoção e uso do pensar reflexivo. "Não basta o conhecimento dos métodos; deve haver o desejo, a vontade de empregá-los. Esse desejo é uma questão de disposição pessoal”.

Mas o que impulsionaria o indivíduo a desejar tornar-se reflexivo? Segundo Dewey, "há porém, algumas tendências e forças que agem em todo indivíduo normal, forças para as quais cumpre apelar e que se devem utilizar, se se pretende empregar os melhores métodos de desenvolvimento de bons hábitos de pensamento". Uma dessas forças seria a curiosidade.

Para toda criatura sadia, cada novo contato é como que um deslumbramento ardentemente procurado, não apenas passivamente esperado e suportado. (...) ...cada órgão sensitivo ou motor, normal, (...) busca oportunidade de ação e, para agir, reclama um objeto. A curiosidade é a soma de todas essas tendências dirigidas para fora. Fator básico da ampliação da experiência é, portanto, ingrediente 
primário dos germes que se desenvolverão em ato de pensar reflexivo.(ibid., p.45)

\section{A REFLEXÃO-AÇÃO EM D. SCHÖN}

A influência do pensamento pedagógico de J. Dewey é sentida em obras de outros pesquisadores da atualidade que também refletem sobre questões educacionais e que a conduziram para uma vertente em especial: a formação de professores. Quando D. Schön desenvolveu suas teorias da reflexão-na-ação, da reflexão-sobre-a-ação e da reflexão sobre a reflexão-na-ação, o fez, primeiramente, a partir da crítica ao racionalismo técnico aplicado sobre a temática da formação de profissionais. Ao entender que a formação do futuro profissional deve incluir um forte componente de reflexão, a partir de situações práticas reais, Schön propõe uma epistemologia da prática, que tem como referência as competências que se encontram subjacentes à prática dos bons profissionais.

Em seu livro Educating the Reflexive Practioner (1987), Schön analisa as ações de profissionais da arquitetura, da música e um psicanalista. Para Alarcão (1996, p.15), "Schön propõe que se olhe para eles, não exatamente para os considerarmos modelos a seguir, mas para os examinarmos no que fazem e no que são e para neles colhermos lições para os nossos programas de formação".

Em seu texto, Formar Professores como Profissionais Reflexivos (1992), Schön se implica com a formação de educadores, ao tratar das intervenções dos modelos de reforma educativa advindas do governo central, sobre as instituições escolares locais. Segundo Schön, um jogo paralelo se estabelece entre as escolas - que tentam preservar sua liberdade de decisão - e os mecanismos de controle das autoridades centrais. Nessas instituições, segundo Schön, percebe-se que os educadores não se encontram preparados para lidar com problemas reais por conta da formação a que são submetidos nas universidades. As teorias e técnicas de solução de problemas que os profissionais (professores) aprendem são 
insuficientes para enfrentarem criativamente as situações complexas das práticas reais. Daí a necessidade de buscar uma nova epistemologia da prática profissional.

Focalizando a ação do profissional, Schön considera dois elementos presentes e atuantes, sobre os quais nos interessa refletir mais adiante, que seriam: o conhecimento na ação e o conhecimento na prática.

A noção de conhecimento na ação surge no campo da competência artística (artistry), uma sensibilidade tácita, manifestada na ação espontânea, quase intuitiva do indivíduo ao lidar com situações novas. É um conhecimento inerente e simultâneo às ações, e completa o conhecimento técnico e científico que o indivíduo já possui. Mesmo havendo dificuldade em traduzir esse conhecimento em palavras numa atitude de reflexão, o indivíduo seria capaz de tomá-lo para uma reformulação da própria ação.

Esse modelo de prática reflexiva supõe que o indivíduo analise o conhecimento na ação, ou seja, por mais intuitivo e espontâneo, esse conhecimento está acompanhado de um componente inteligente, racional, que orienta toda atividade humana. Isto significa considerar que "há um tipo de conhecimento em qualquer ação inteligente, ainda que este conhecimento, fruto da experiência e da reflexão passadas, se tenha consolidado em esquemas semiautomáticos ou em rotinas" (Pérez-Gómez, 1992, p.104).

Em relação ao conhecimento na prática, Schön leva em conta os conhecimentos adquiridos através da experiência acumulada do profissional, revalorizada pela reflexão e que desafia os profissionais a irem além das rotinas e técnicas já conhecidas na resolução de questões problemáticas. É uma aprendizagem gerada na prática, no aqui e no agora da situação.

Diante de tais parâmetros, nesse texto Schön se debruça sobre a questão: "Que tipos de formação serão mais viáveis para equipar os professores com as capacidades necessárias ao desempenho do seu trabalho?"(ibid.,p.80). Desenvolver nos professores uma capacidade de refletir na e sobre a prática seria a resposta dada para a pergunta. Contudo, Schön destaca a importância de articular três dimensões da reflexão sobre a prática: a compreensão das matérias pelo 
aluno; a dimensão burocrática da prática e a interação interpessoal entre $o$ professor e $o$ aluno.

$\mathrm{Na}$ primeira das dimensões, Schön se refere à importância do professor prestar atenção ao aluno, procurando "descobrir as razões que levam as crianças a dizer certas coisas", ouvindo e se deixando surpreender pelo aluno, enquanto aprendiz de um saber escolar. Nesse âmbito o professor não deverá perder a oportunidade de refletir-na-ação e posteriormente, refletir sobre a reflexão-na-ação. Esse processo se sucederia como ele descreve:

O processo de reflexão-na-ação (...) pode ser desenvolvido numa série de "momentos" sutilmente combinados numa habilidosa prática de ensino. Existe, primeiramente um momento de surpresa: um professor reflexivo permite-se ser surpreendido pelo que o aluno faz. Num segundo momento, reflete sobre esse fato, ou seja, pensa sobre aquilo que o aluno disse ou fez e, simultaneamente, procura compreender a razão por que foi surpreendido. Depois, num terceiro momento, reformula o problema suscitado pela situação. (...). Num quarto momento, efetua uma experiência para testar sua nova hipótese; por exemplo, coloca uma nova questão ou estabelece uma nova tarefa para testar a hipótese que formulou sobre o modo de pensar do aluno. (...)

Por outro lado, é possível olhar retrospectivamente e refletir sobre a reflexão-na-ação. Após a aula, o professor pode pensar no que aconteceu, no que observou, no significado que lhe deu e na eventual adoção de outros sentidos (ibid.,83).

Sobre a dimensão burocrática da prática, Schön pergunta "Como é que o professor vive e trabalha na escola e procura a liberdade essencial à prática reflexiva?". Segundo Schön, quando um professor tenta refletir sobre sua ação na escola, esbarra com a burocracia institucional, que prevê mecanismos de controle sobre o progresso dos alunos como conseqüência da atuação dos professores. Assim, para que se evitem conflitos, gestores e professores devem trabalhar juntos na criação de um clima favorável para a prática reflexiva.

Nesse momento, o professor pensa em suas atitudes na escola, reflete sobre si, enquanto sujeito que age, que toma decisões nesse espaço. Nesse momento, surge então a oportunidade de se perguntar o que o impulsiona a fazer determinadas escolhas. Assim como no exemplo citado por Schön: 
A experiência dos professores que seguiram até o fim o Teacher Project é muito elucidativa, ainda que algo deprimente. Um deles disse: Vou deixar a minha escola. O que aprendi aqui é demasiado bom para ela.(ibid., p.87)

$\mathrm{Na}$ terceira dimensão, sobre a interação interpessoal entre o professor e $\mathrm{o}$ aluno, Schön se detém em questões do tipo: "Como é que o professor compreende e responde a outros indivíduos a partir do ponto de vista da sua ansiedade, controle, diplomacia, confrontação, conflito ou autoridade?". Vejamos como Schön aborda um exemplo:

Imaginemos que (...) um professor pergunta: Viste o eclipse ontem?; e
um dos alunos responde: O meu pai disse que não houve, porque o céu
estava carregado de nuvens. Se o professor se sentir ansioso
relativamente à sua própria autoridade, a resposta pode provocar-lhe
uma atitude defensiva e o desejo de reassumir a autoridade. (...) Se
começar por tomar uma atitude defensiva, terá de entender esse seu
impulso e transformá-lo em curiosidade (...) Este posicionamento algo
paradoxal é necessário se, o professor quiser funcionar como um
profissional reflexivo. Caso contrário, sentir-se-á assustado ao ver-se
confrontado com um erro que cometeu e tentará controlar a situação
para evitar que seu erro venha a ser descoberto. (ibid.,p.87)

Se considerarmos a reflexão como entende Schön, seria possível levar um indivíduo a conhecer quais os conhecimentos que ele incorpora em suas ações, mesmo que tais conhecimentos estejam implícitos e o levem a rotinas automáticas e mecânicas em suas práticas. Uma reflexão levada a esse nível tornaria conscientes "normas, credos e apreciações tácitas subjacentes aos processos de valoração, estratégias e teorias implícitas que determinam uma forma concreta de comportamento, sentimentos provocados por uma situação, a maneira como se define e estabelece o problema e o papel que o profissional tem dentro do contexto institucional em que atua" (Pérez-Gómez, 1992, p.106).

\section{PARA ALÉM DE J. DEWEY E D. SCHÖN: A REFLEXÃO NUMA PERSPECTIVA PSICANALÍTICA}

Pelo exposto anteriormente a respeito do pensamento reflexivo de Dewey e desse pensamento aplicado à formação de profissionais por $\mathrm{D}$. Schön, percebe-se 
que o sujeito dessa ação, isto é, o sujeito do ato de pensar e resolver problemas práticos, opera a partir da mobilização de sua consciência e racionalidade. Mesmo que os autores admitam que o sujeito da ação, enquanto atua, seja sustentado também por emoções, sentimentos e afetos e ao refletir-na-ação ou sobre-a-ação, além de utilizar um conjunto de conhecimentos técnicos, mobilize sua intuição, criatividade, e conhecimentos adquiridos na prática, e ainda admita que componentes de incerteza, de imprevisibilidade, de subjetividade circundem 0 problema a ser resolvido, ainda assim, o sujeito em questão é, em última instância, o sujeito da razão.

O sujeito da razão é o sujeito do pensamento, aquele definido por Descartes como "penso, logo existo". Sem, obviamente, negar ou excluir esse sujeito, pretendemos aqui concebê-lo também de acordo com o referencial teórico que escolhemos: o da psicanálise. Para a Psicanálise o sujeito também é sujeito do pensamento, da razão, mas de uma outra razão, para Freud, a razão inconsciente. Enquanto para Descartes o sujeito é uma coisa pensante, para a psicanálise o sujeito aparece na dúvida, na hesitação. Em Descartes, há uma substantificação do sujeito na medida em que ele é uma coisa, uma coisa pensante, enquanto que para a psicanálise, o sujeito é sem substância. Para Descartes o sujeito está onde pensa "Lá onde penso, eu sou"; para Lacan, relendo Freud, o sujeito está no pensamento ausente "Lá onde penso eu não estou, eu não sou". Se o sujeito não está onde o pensamento o identifica, então, onde está o sujeito psicanalítico?

O sujeito para a psicanálise é essa lembrança apagada, esse significante que falta, esse vazio de representação em que se manifesta o desejo. (....) $O$ sujeito que a psicanálise descobre nos escombros das patologias, nos caleidoscópios oníricos, nas fantasmagorias da ópera privada, nos corredores das vesânias - esse sujeito é fundamentalmente desejo. (...) Desejo, logo existo. (Quinet, 2000,p.13)

O sujeito aparece então, pela primeira vez, como dividido por Freud entre 0 consciente e o inconsciente. O sujeito consciente é o eu, aquilo que apresento ao outro, o auto-retrato, uma auto-imagem, um retrato falado estabelecido pela via da 
linguagem. $O$ inconsciente também se expressa pela linguagem, ou melhor, como postula Lacan, "o inconsciente é estruturado como linguagem".

Mas é na fala que o inconsciente emerge e se faz existir. Isso significa que a fala de um indivíduo, que pensa saber e dominar o que diz é, independente de sua vontade, atravessada pelo pensamento inconsciente e marcada pelos tropeços da língua. A isso equivale dizer que o pensamento reflexivo, quando expresso pela fala, sofre as mesmas intervenções, isto é, não está livre das interferências do pensamento inconsciente.

O modo de pensar que Dewey chamou de "corrente da consciência", elevado ao nível das divagações sem conseqüências, não tem validade para o autor como algo útil, quando o objetivo é tomar o pensamento como algo "sério e consecutivo". No entanto, a divagação livre das idéias e do que "passa pela cabeça", na medida em que o sujeito fala, nada mais é do que o ponto de partida para o analista, o material contido no inconsciente, sobre $o$ qual $o$ analista e $o$ analisando vão trabalhar.

Em psicanálise a técnica segundo a qual o paciente deve exprimir, durante o tratamento, tudo o que Ihe vem à mente, sem nenhuma discriminação, dá-se o nome de método de livre associação, tendo se tornado desde então, a regra fundamental no tratamento psicanalítico: o meio privilegiado de investigação do inconsciente.

O paciente deve exprimir todos os seus pensamentos, idéias, imagens e emoções, tais como se apresentam a ele, sem seleção e restrição, mesmo que tais materiais the pareçam incoerentes, impudicos, impertinentes ou desprovidos de interesse. Tais associações podem ser induzidas por uma palavra, um elemento de sonho, ou qualquer outro objeto de pensamento espontâneo. $O$ respeito a essa regra permite o aparecimento das representações inconscientes e atualiza os mecanismos de resistência. (Chemama, 2002, p.22).

Portanto, entendemos que o material proveniente da fala livre e espontânea, embora não seja tratado por Dewey como pensamento reflexivo, a nosso ver não pode ser desprezado; ao contrário, traz substância para a reflexão. 
O pensamento reflexivo, como ato consciente, pressupõe uma seqüência lógica e ordenada de idéias, transformando-se numa cadeia, o que de fato não ocorre na "mera sucessão irregular disto ou daquilo". Também com o pensamento inconsciente ocorre algo semelhante a uma seqüência lógica e ordenada de unidades definidas, de modo que caberia fazer um paralelo. Para isso, tomemos algumas explicações a respeito da estrutura do inconsciente. De acordo com Lacan, o inconsciente é estruturado como linguagem, como já dissemos. Como linguagem ele apresenta unidades definidas, os significantes, que guardam entre si uma gramática regida por leis próprias e autônomas e também formam uma cadeia, a cadeia de significantes. Eis como Quinet (2000) explica o significante e sua manifestação na fala do sujeito:

O significante é apenas o som esvaziado de sentido, como uma palavra estrangeira desconhecida ou o nome próprio que, embora designe, nada significa.(...) Eis o que a psicanálise permite apreender no esquecimento, no ato falho, no chiste, no lapso e também no sintoma que apresenta essa mesma estrutura de linguagem. (...) O processo da análise é o processo de deciframento dessa articulação significante, que nada mais é do que um desdobramento, um desenrolar das cadeias de associação significantes.(Quinet, 2000,p.37-39)

Segundo Lacan há duas cadeias de discurso que caminham aproximadamente paralelas uma à outra, que seriam a fala e o pensamento inconsciente, uma das quais às vezes interrompe ou intervém na outra, por exemplo:

Numa conversa, podemos falar a um amigo que fizemos uma blister (bolha) no pé ao correr, o lapso parapraxal para sister (irmã) indica que outro pensamento nos preocupa em outro nível - ao nível do inconsciente. Algo que o interlocutor nos disse pode nos fazer lembrar de uma irmã, mas também pode ser que nada na atual situação de fala provocou os pensamentos sobre ela, e que uma certa reflexão inconsciente estava acontecendo desde o começo do dia quando falamos com ela ao telefone ou sonhamos com ela.(Fink,1998,p.33)

Dewey nos coloca o pensar reflexivo como conduta que segue uma investigação do tipo científica, portanto as crenças não se encaixam nesse modelo. Contudo, as crenças são materiais de reflexão, já que, como o próprio autor diz, "confiamos o bastante para nelas basear a nossa ação". Ao refletir sobre as crenças, o sujeito se determina a investigá-las, "a fim de se descobrirem as bases em que repousam", ou seja, as razões pelas quais o sujeito as criou. E essas 
razões podem ser profundas, menos perceptíveis ao intelecto, por serem razões do pensamento inconsciente.

$\mathrm{Na}$ educação, é comum os professores construírem crenças a respeito dos alunos, da escola, da educação e com base nelas tomarem decisões. Nosso referencial nos permite considerar que nas ações de um profissional, no caso dos professores, além dos componentes racionais ou inteligentes da porção consciente, estão presentes também os componentes advindos do inconsciente. Isto significa que, além do conhecimento-na-ação que, segundo Schön, é tácito nos profissionais e manifesta-se na espontaneidade com que uma ação é desempenhada, reconhecemos que as ações dos sujeitos também estão repletas de nãoconhecimentos. Isso equivale admitir a existência de um não-conhecimento-naação, que o sujeito não consegue perceber por si como elemento atuante e presente na ação. Esta falta de percepção sobre o não-conhecimento conduz o sujeito a uma dificuldade e até a uma recusa em falar sobre isso, no sentido de se perguntar por que ele age de determinada forma.

Dewey nos faz entender que uma pessoa, imersa num pensamento reflexivo poderá sair de uma situação embaraçosa para uma outra satisfatória. No entanto, é preciso discutir se o pensamento reflexivo, como etapa antecessora da ação, garantiria posteriormente, uma ação também satisfatória, na mesma direção da reflexão realizada. De acordo com o referencial psicanalítico, o sujeito pode agir impulsionado por elementos inconscientes, sobre os quais sua consciência não detém o controle.

Para evitar as conseqüências ou atingir os objetivos de seus atos, o homem aperfeiçoa e combina sinais por meio do pensamento. Essa característica, para Dewey, que "estabelece a diferença entre o selvagem e o irracional, também estabelece entre o homem civilizado e o selvagem". No entanto, o sujeito que age mesmo amparado por um pensamento reflexivo ou, em função dele, planeja sua ação, não escapa de uma prática ambígua, sem que possa, por isso, ser nomeado 
de irracional ou selvagem. Uma ação não é sempre racional. O controle que se pretende ter da natureza prática do pensar reflexivo, a partir da contenção de impulsos e apetites e da manipulação de objetivos e resultados de ações, nos parece limitado, uma vez que o sujeito não só usa, mas também é usado pela linguagem.

O sentido das coisas, principalmente das palavras, da linguagem, como privilegia a psicanálise, tem fundamental importância na formação do inconsciente. Uma palavra pode adquirir um sentido outro para um sujeito que a ouve. Nesse caso, estamos falando novamente dos significantes. Independente da capacidade lógica do sujeito pensar reflexivamente, de ampliar intelectualmente o significado das coisas, certamente seu inconsciente será marcado por significantes. A cadeia de significantes em si não traz sentido, ao contrário, a ela falta sentido.

Presuma que o Homem dos Ratos ouviu por acaso uma parte da conversa dos pais incluindo a palavra Spielratte (jogador) e, embora fosse jovem demais para entendê-la, foi contudo registrada $e$ indelevelmente gravada em sua memória. Lá, ganhou vida própria, formando vínculos com outras cenas testemunhadas e palavras ouvidas por acaso, não dirigidas aos seus olhos ou ouvidos de propósito. Seu inconsciente foi transformado de maneira irremediável pelo que ele ouviu, e "o que se ouve é o significante", não o significado.(Fink, 1998,p.41)

Diferentemente do exemplo de Dewey, sobre os sentidos intelectualmente ampliados e enriquecidos que ganhariam os objetos e fenômenos, a partir de uma reflexão (ver o exemplo dado por ele para a palavra água); o exemplo do Homem dos Ratos mostra que uma palavra (Spielratte) não apenas pode ter seu sentido atribuído pela consciência; o som que ela reverbera (significante) pode se associado a infinitos outros sentidos em seu inconsciente. Sendo assim, poderá, a qualquer momento, emergir em sua fala totalmente desprovido de sentido. 
Já a idéia de Locke, apresentada por Dewey, para nos falar sobre os indivíduos que pensam sob a influência dos "pais, os vizinhos, os ministros de sua religião ou quem quer que Ihes agrade", nos remete ao conceito de grande Outro na psicanálise. O Outro é aquele a quem prestamos conta inconscientemente, sejam eles, pais, professores, Deus, leis, analista, uma autoridade. Em Lacan temos várias faces do Outro e numa delas o Outro é concebido como linguagem. Daí Lacan afirmar que "o inconsciente é o discurso do Outro". Nesta acepção, a linguagem dos outros é assimilada pelo indivíduo e armazenada em seu inconsciente e quando esse inconsciente se manifesta, o Outro fala. Na linguagem, são expressos desejos e opiniões de outras pessoas de modo que a afirmação de Lacan pôde ser interpretada por Fink: "o inconsciente está repleto da fala de outras pessoas, das conversas de outras pessoas, e dos objetivos, aspirações e fantasias de outras pessoas".

Às vezes, muitas pessoas sentem que estão trabalhando em algo que nem
sequer realmente desejam, empenhando-se para corresponder a
expectativas que nem mesmo endossam, ou declarando objetivos que
sabem perfeitamente bem que têm pouca ou nenhuma motivação para
alcançar. O inconsciente está, nesse sentido, transbordando de desejos
de outras pessoas...(ibid.,p.26)

Concepções e valores adquiridos em grande parte na infância, podem permanecer muito tempo no sujeito, que neles continua crendo e, de acordo com eles, atuando, ainda na idade adulta. Como ao inconsciente cabe registrar e atualizar esses dados, automaticamente faz com que o sujeito entre num circuito de repetições de atos e resultados sem conseguir se dar conta deles. Conforme já foi dito, o sujeito pode estar alienado no Outro, no discurso do Outro.

Um sujeito pode ser mantido alienado no e pelo Outro e dessa forma estar sempre se apresentando ao Outro, procurando atrair a atenção e o reconhecimento do Outro, ou seja, sendo castrado. Nesse caso, uma outra acepção de Outro surge para Lacan; o Outro como demanda, para quem o sujeito direciona suas demandas de saber, de ajuda, de aprovação, atenção, afeto; enfim, demanda de amor.

No caso de uma análise, por exemplo, o analista pode ocupar o lugar do Outro como demanda e manter o analisando alienado em seu saber. Essa é uma posição 
necessária pois é a partir dela que o analista trabalha a transferência. É através do estabelecimento desse vínculo com o analista, que o analisando se sente confiante para falar, tentar descobrir e compreender o que está acontecendo com ele. E mais, quando um paciente se dirige a um analista, já supõe nele um saber sobre o que busca em si mesmo. O analista encarna uma autoridade que a princípio sabe, ou seja, o chamado Sujeito Suposto Saber.

No entanto, o Outro também é postulado por Lacan como Outro do desejo. Toda criança tenta ser objeto de desejo de seus pais, estar no lugar para onde eles possam voltar todo o seu interesse; principalmente em relação à mãe, a criança se preocupa em ocupar o espaço total do seu desejo. Mas quando a criança se depara com essa impossibilidade - já que a mãe deve dirigir seus interesses também para outros lugares ou pessoas - no momento da introdução de um terceiro termo (Nome-do-Pai), a unidade mãe-criança é rompida. Deverá ocorrer então a separação, quando o sujeito é expulso do campo do desejo do Outro para assumir seu desejo próprio.

O sujeito deve renunciar a sua posição mais ou menos confortável, complacentemente miserável, como assujeitado pelo Outro - como castrado - para tomar o desejo do Outro como causa para si. (...) $O$ sujeito castrado é, portanto, um sujeito que não subjetivou o desejo do Outro e que permanece afligido por ele e ainda obtém um "ganho secundário” de sua submissão sintomática ao Outro.(ibid.,p.97)

É após o rompimento da unidade hipotética mãe-criança, que para Lacan o sujeito advém como dividido entre consciente e inconsciente. Dessa divisão sobra um resto, que Lacan chamou de objeto a, causa do desejo. A falta do desejo do Outro é causa do desejo próprio do sujeito. Mas o objeto a é também o último resquício da unidade mãe-criança ao qual o sujeito pode continuar apegado, sustentando então uma ilusão de totalidade, a que Lacan chama de fantasia.

Ao contarem suas fantasias para seus analistas, os analisandos informam sobre o modo como desejam estar relacionados com o objeto a; em outras palavras, a forma como eles gostariam de estar posicionados com relação ao desejo do Outro. (ibid.,p.83) 
O papel do analista é ajudar o analisando a fazer a travessia da fantasia, isto é, mudar a relação do sujeito com o objeto a; "onde uma vez reinou o discurso do Outro, dominado pelo desejo do Outro o sujeito é capaz de dizer Eu”.

Lacan chega a sugerir que o analista ocupe o lugar de objeto $a$, causa de desejo no analisando. O analista passaria da posição de Outro da demanda, para o qual o paciente demanda saber e verdade sobre suas questões, para o Outro do desejo, empenhando-se em encarnar a capacidade de desejar, de inspirar desejo no analisando.

Aqueles que, para Dewey, inspirado em Locke, equivocam seu pensamento por não assumirem opiniões próprias - com base em idéias "sagradas" de pais, amas ou outras pessoas com quem se achem em contato - para nós, que estamos de acordo com o referencial psicanalítico, permanecem submissos inconscientemente ao Outro. Essa submissão, encontrada nas fantasias que o sujeito constrói e manipula, traz uma emoção - que pode ser tanto de prazer como de dor - que Lacan denominou de gozo.

É nas fantasias, nas palavras, nos atos inesperados, nos sonhos, no sintoma, ou seja, nas manifestações do inconsciente, que o sujeito pode liberar parte da energia retida no interior do sistema psíquico. Esta descarga parcial é denominada gozo fálico. A parte que permanece confinada, fruto do recalcamento do impulso do desejo, provoca uma tensão que é aumentada constantemente no interior do psiquismo. Trata-se de um gozo residual, o mais-gozar.

Para Freud, a felicidade absoluta corresponderia ao prazer sexual absoluto experimentado pelo incesto. Como o recalcamento age no sentido de impedir a realização desse desejo, esse estado pleno de felicidade é impossível de se alcançar. Para Lacan, significaria alcançar o gozo absoluto ou gozo do Outro. É o gozo ideal, que na fase edipiana corresponderia à realização do incesto, para um neurótico obsessivo seria a morte, para um histérico seria a loucura. De qualquer forma, a obtenção desse gozo, ou a realização do desejo cessaria toda a tensão e 
conseqüentemente toda a vida. O gozo mantém a vida, pois é a força que mantém o sujeito desejante.

Existem muitas formas do sujeito gozar, ou seja, do sujeito buscar a realização do seu desejo, embora ele tenha que se contentar com o ganho parcial de satisfações nesse caminho de busca. Uma dessas formas, já o dissemos, seria na construção de fantasias, nas quais o sujeito mostra como é a sua relação com o Outro.

O corpo, para Lacan, é um lugar de gozo. Há sujeitos que realizam o gozo parcial condensando-o num certo segmento do corpo; outros utilizam-se do corpo todo. Um exemplo, trazido por Forbes (1999) em seus seminários sobre a Segunda Clínica de Lacan, é a procura dos jovens pelos esportes radicais. Para ele, essa forma de gozar, que impulsiona os jovens à procura por emoções fortes no alpinismo, no triatlon, nas corridas de automóvel, no bung jump, revela uma relação de ausência com o Outro, onde tudo é permitido.

A não existência do Outro no mundo globalizado, talvez se explique no crescimento dos esportes radicais, na necessidade do adolescente responder, de organizar o gozo irrefreável da carne. Com a desregulação do Outro, da família e da religião faltam operadores que eram fundamentais. (...) Vivemos num momento em que nada mais é proibido pelo Outro. (Forbes, 1999,I,p.7)

Voltando a Dewey, o pensamento equivocado pela paixão a que se entrega o sujeito mediante seus atos, pode ser interpretada pela psicanálise no nível da pulsão. A pulsão pode levar o sujeito a ações contrárias ao seu pensamento consciente.

O inconsciente não é pura articulação de significantes. O inconsciente é pulsional. (...) Nos anos 20, Freud encontra o que considera seu verdadeiro dualismo pulsional: Eros tende à vida, à aspiração ao Um, à reprodução, e a pulsão de morte é destrutividade e desunião, o impulso que na vida só quer morrer. (Quinet,2000,p.47) 
Para Freud, os impulsos (ou pulsões) quando barrados pelo consciente se transformam em recalque; pulsões recalcadas constituem o inconsciente. Freud diz que "a relação com o recalcado age com tal intensidade que ele deve repetir sua tentativa de recalque". Isso significa que as pulsões reprimidas ou recalcadas tendem a retornar, manifestando-se na forma de sintoma. A pulsão não quer ser contrariada e reinicia sua investida na forma de atos repetitivos.

Portanto, onde o pensamento reflexivo, racional como o supõe Dewey, ordena que o sujeito vá em determinada direção, a pulsão o faz girar em torno de si, fazendo com que se retorne sempre ao mesmo lugar.

Uma outra característica da pulsão é a sua resistência a mordaças. A função do analista não é o de domar as pulsões, com o risco de se deparar com surpresas. Sobre isso, Forbes faz uma analogia interessante.

Se o psicanalista fizer o que foi feito na Holanda, ou o que Lacerda fez no Rio de Janeiro, construir o jardim de Burlemarx sobre o aterro do Flamengo, sobre o mar da baía de Guanabara, se ele ganhar terreno sobre o mar das pulsões, certamente haverá maremoto, haverá revolta do mar das pulsões. São interessantes os comentários dos estudiosos sobre tais conquistas, uma certeza quanto à reação da natureza. Em outros termos, não se conquista a natureza, não se amordaça pulsões impunemente. As pulsões não se deixam amordaçar - é a tese de Lacan. (Forbes, 1999, V,p.2)

Ao invés de domar a pulsão, o analista pode ajudar o sujeito a canalizá-la para algo mais criativo.

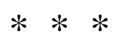

Finalmente, o que Dewey resume como atitudes do indivíduo para favorecer o pensamento reflexivo - espírito aberto, coração e responsabilidade - ou seja, atitudes dos quais se deve dispor aquele que pretende usar o raciocínio lógico para uma investigação, interpretamos como posturas que o sujeito deve assumir ao questionar suas posições em relação ao Outro(s), ao seu gozo e ao seu desejo. 
Em psicanálise partimos da pressuposição da existência de um sujeito dividido, castrado, assujeitado pelo Outro. A divisão que leva o sujeito à confusão, por sua vez geradora de angústia, está dada pela batalha que o consciente e inconsciente travam no real, já que operam a partir de lógicas controversas. $O$ espírito aberto nada mais é do que a predisposição do sujeito para encarar sua angústia e procurar outros modos de lidar com ela.

Na postura de coração, o sujeito aceita a sua divisão, sua incompletude e tenta descobrir o que dele pertence ao Outro.

Enfim, no momento em que o sujeito assume a responsabilidade pelo seu desejo, está promovendo a sua separação, a sua desalienação do Outro. Responsabilizar-se pelo cerne do ser, é a proposta de Forbes:

Por quê?? Por não haver mais possibilidades de jogar a bola para frente,
por não ser mais possível se queixar da vida, pela impossibilidade de
fazer mais uma sessão de análise para obter uma resposta do
inconsciente, enfim, simplesmente porque não dá mais para repetir com
Sartre que "O inferno é o outro".(ibid.,p.2)

"Mas o que impulsionaria o indivíduo a desejar tornar-se reflexivo?", pergunta Dewey. Uma força que agiria em todo indivíduo e que o impulsionaria para a ação de conhecer, de saber mais, é a curiosidade. Perguntamos: o que impulsionaria o sujeito a questionar sua posição em relação ao Outro, ao seu gozo e ao seu desejo? A falta. A busca incessante pelo saber, o desejo de saber, se refere a um preenchimento de uma falta, que é constitutiva do sujeito. Falta e desejo estão sempre relacionados. A falta causa desejo e o desejo é o enigma que impele o sujeito a saber o que o anima em sua existência. Por outro lado, a falta cria a angústia da castração porque coloca por terra todo e qualquer ideal de harmonia em que o sujeito seja inteiro. 
Entendemos que, estando o sujeito no foco de qualquer ação, nossa trajetória até aqui corre no sentido de demonstrar nosso interesse numa reflexão sobre $o$ sujeito da ação. Melhor dizer, um questionamento a respeito das posições do sujeito frente aos elementos centrais que colocamos em discussão, a saber, o Outro, o gozo e o desejo.

Questionar essas posições requer que o profissional identifique e reconheça a que Outro(s) se assujeita, submete e aliena. Significa que ele identifique e reconheça em suas rotinas e processos, o circuito de repetições de práticas e resultados aos quais, se mantendo preso, goze, isto é, obtenha uma satisfação inconsciente. Também significa que ele, ao identificar e reconhecer, se prepare para se separar do(s) Outro(s) e assumir a responsabilidade pelo seu desejo.

Um questionamento dessa ordem exige ir além da superficialidade do pensamento egóico, além da simples reflexão racional. Tudo o que para Dewey e Schön estaria fora do pensamento reflexivo, em nossa proposta constitui material a ser incluído no questionamento das posições do sujeito.

Em termos das práticas reflexivas desenvolvidas na formação de professores, vejamos a seguir sob quais focos elas são abordadas e em que medida o questionamento das posições do sujeito frente ao(s) Outro(s), ao gozo e ao desejo, pode ser incorporado a esse trabalho de formação.

\section{A PRÁTICA REFLEXIVA NA FORMAÇÃO DE PROFESSORES}

Nos últimos tempos, a prática reflexiva tem sido sugerida como conduta essencial no que se refere à formação de professores, tanto no seu início como no prolongamento da carreira docente. A tendência para uma conduta reflexiva tem colocado em discussão a capacitação docente e, conseqüentemente, trouxe transformações quanto ao seu conceito, epistemologia, finalidades e possibilidades de resultados. 
É consenso entre pesquisadores e educadores, por exemplo, que a modalidade de capacitação denominada reciclagem ou treinamento em serviço, que sugere preocupação com o produto, já não seja suficiente para sanar as deficiências formativas e o preparo inadequado, tanto do grande número de egressos das universidades que se dirigem ao magistério quanto dos profissionais em exercício. Em lugar de uma ação pontuada, esporádica e desconectada das necessidades e do lócus dos professores, pretende-se uma ação contínua, uma forma permanente de educação que possibilite aos professores uma aprendizagem constante, contextualizada, processual, que Ihes dê o apoio necessário para a aquisição de uma autonomia ao longo de sua caminhada como educador. A educação contínua seria desejável na medida em que, eliminando a idéia de produto acabado e tempo limitado para ocorrer, permitiria um aprofundamento e um envolvimento maior nas questões da docência, oferecendo, portanto, condições mais adequadas para a prática reflexiva.

O investimento numa educação contínua começa com iniciativas dentro da própria universidade, com os futuros professores em fase de conclusão da licenciatura. A vivência da realidade da sala de aula, o contato com os problemas reais dos professores na escola e na comunidade, além de proporcionarem 0 confronto entre a teoria e prática, permitem ao aprendiz a conscientização da natureza continuada da educação do professor, segundo Celani (1988).

O período dos estágios de ensino como alvo de pesquisas sobre a formação inicial de professores produz excelente oportunidade para estudos sobre o "pensamento do professor". Um dos enfoques dessa linha de pesquisa tem apresentado trabalhos que analisam as crenças e teorias trazidas pelos professores quando iniciam sua formação (Pajares, 1992; Hollingsworth, 1989; Rodríguez, 1993; Knowles, 1992; Hoy e Woolfolk, 1990) e a evolução das mesmas sob o efeito dos estágios de ensino. Como os resultados dessas pesquisas mostraram que as crenças a respeito do ensino e da aprendizagem pouco se alteram durante os estágios, a prática reflexiva surge como uma conduta mediante a qual os professores modificariam as referidas crenças. Despontam, nesse momento, pesquisadores (Ross, 1990; Van Maanen,1985, Sparks e Colton, 1991) e 
programas (CITE, 1991; PROTEACH, 1990) que se esforçam em desenvolver instrumentos para verificar e avaliar as mudanças nos níveis reflexivos dos professores.

A partir daí, várias estratégias para desenvolver a capacidade reflexiva dos professores em formação foram levadas a cabo como, por exemplo, a redação de diários (Hoover, 1994; Surbeck, Han e Moyer, 1991; Wedman, 1990; Rodríguez López, 1994), a análise de gravações de vídeos (Marcelo, 1995) e os portfolios (Bullough, 1993). Nesta perspectiva vale ressaltar a pesquisa de Bullough, que avaliou a utilização de textos pessoais como instrumento para propiciar a reflexão dos professores em formação. Segundo o autor, "os textos permitem que os professores em formação estejam em contato com seu próprio desenvolvimento: aumenta sua auto-confiança; ajuda a verem-se a si próprios como produtores de conhecimento legitimado, ajuda-os a considerar seus valores [...] facilita a reflexão dos professores"(Bullough, apud Garcia, 1998,p.59).

A perspectiva de uma formação baseada na prática reflexiva pretende formar o prático reflexivo, aquele que investiga e constrói conhecimentos a partir da própria prática. Todavia, segundo Contreras (1997) o uso indiscriminado do conceito de reflexão na literatura pedagógica tem sofrido alterações quanto ao seu sentido original. Garcia (1992) alerta para a grande dispersão semântica da sua concepção e a diversidade metodológica envolvida em cada uma, de acordo com diversos autores:

...prática reflexiva, formação de professores orientada para a indagação, reflexão-na-ação, o professor como controlador de si mesmo (Elliot), professores reflexivos (Cruicksank \& Applegat; Zeichner), o professor como pessoa que experimenta continuamente (Stratemeyer), professores adaptativos (Hunt), o professor como investigador na ação (Corey \& Shumsky), o professor como cientista aplicado (Brophy \& Everston; Freeman), professores como sujeitos com um ofício moral (Tom), professores como sujeitos que resolvem problemas (Joyce \& Harootunian), professores como sujeitos que colocam hipóteses (Coladarci), professores como indagadores clínicos (Smyth), professores auto-analíticos (O'Day), professores como pedagogos radicais (Giroux), professores como artesãos políticos (Kohl) e o professor como acadêmico (Ellner).(Garcia, 1992, p.59) 
Cabe, portanto, resgatar que todas essas variações semânticas e abordagens metodológicas tiveram suas raízes a partir dos estudos de D. Schön sobre o profissional como prático reflexivo, cujas obras mais importantes The Reflective Practitioner (1983) e Educating the Reflective Practitioner (1987), tiveram por foco outras áreas que não a de formação de professores, como Arquitetura, Desenho e Engenharia. Somente em seu texto Formar Professores como Profissionais Reflexivos (1992), Schön se implica com a formação docente, cujas teorias iremos abordar com detalhes mais adiante.

Ao longo do século XX, enquanto prevaleceram os programas de formação de profissionais que seguiam a lógica da racionalidade técnica, alguns pesquisadores (Habermas, 1971, 1979; Schön, 1983, Pérez,1983; Zeichner,1987) reconheceram os limites e lacunas de uma prática que se restringe ao apoio de um conhecimento técnico-científico-instrumental, na resolução de situações problemáticas como as enfrentadas pelos professores na sala de aula. As correntes epistemológicas que surgiram a partir desses autores, "têm em comum o desejo de superar a relação linear e mecânica entre o conhecimento científico-técnico e a prática da sala de aula" (Pérez-Gómez, 1992).

O trabalho de Zeichner (1992), embora aponte na mesma direção de Schön, amplia o conceito de professor reflexivo. $O$ autor entende que na prática de um ensino reflexivo, a atenção do professor não deve apenas se limitar à própria prática, mas ela deve, além de abranger o contexto social na qual ela se situa, ser orientada para a sua reconstrução.

Ao longo da nossa participação em projetos centrados na preparação de professores para um trabalho aberto e autêntico com as comunidades, aprendemos sobre o modo de sensibilizar os professores para valores, tipos de vida e culturas diferentes das suas e a desenvolver o seu respeito pela diversidade humana. (Zeichner, 1992,p.129)

Zeichner chama de atitude narcísica a prática reflexiva que tem um fim em si mesma, que ignora as condições sociais e institucionais do entorno dos professores e que, a seu ver, distorcem a compreensão que eles têm de si próprios. Embora não rejeite a proposição de que o conhecimento exterior, aquele que demonstra os processos cognitivos dos alunos, as formas de pensar e os comportamentos dos 
professores, sejam elementos essenciais num programa de formação que inclua um practicum, Zeichner reconhece os limites desse tipo de conhecimento e prefere pensar que "as escolas e as comunidades se tornam espaços de prática, em vez do usual enquadramento ao nível limitado das salas de aula e dos professores". O que Zeichner propõe é que se façam não só alterações nas interações da sala de aula, mas que estejam comprometidas a escola, a comunidade e as estruturas sociais na valorização da reflexão e ação coletivas.

A respeito das teorias expostas, considerando seus matizes e amplitudes, "a reflexão é vista como um processo cognitivo que poderá levar o professor a conquistar uma compreensão das razões, motivos, valores e pressões que influenciam seu trabalho pedagógico" (Paiva, 2003:60). Entendemos, portanto, que quando esta reflexão se dá, os sujeitos envolvidos se implicam numa reflexão de ordem racional, intelectual, cognitiva, e consciente.

\section{A prática reflexiva na linha da subjetividade}

Mais recentemente, encontramos o modelo da prática reflexiva sendo ampliado por alguns pesquisadores (Cifali, 2001; Perrenoud, 2001; Aquino, 2000, 2001; Pacca \& Villani, 2000; Arruda, 2004; Bacha, 2002) para uma dimensão mais subjetiva, que centra a atenção nas referências implícitas que orientam as práticas dos sujeitos.

Perrenoud (2001), por exemplo, utiliza-se do conceito de habitus, de Bourdieu, para explorar as ações pedagógicas e suas relações com a construção de rotinas na evolução da vida profissional dos professores. A gênese do habitus nos sujeitos é explicada por Bourdieu "pela interiorização de limites objetivos, por um aprendizado através de tentativas e erros que progressivamente vai selecionando respostas adequadas ao ambiente físico e social”. São as posições sociais que geram no psiquismo individual, disposições (o habitus) que, por sua vez, produzem representações e práticas. Apesar de socialmente estruturado, Perrenoud admite um trabalho e um domínio individual sobre a construção e a transformação do habitus, no nível psíquico dos professores. Para ele, a tomada de consciência e a 
transformação do habitus dos professores passa, entre outros, pelo mecanismo da prática reflexiva:

...consciência de si, metacognição, epistemologia da ação ou simplesmente lucidez. Qualquer que seja o vocabulário, ele designa uma forma de reflexividade: o sujeito toma sua própria ação, seus próprios funcionamentos psíquicos como objeto de sua observação e de sua análise; ele tenta perceber e compreender sua própria maneira de pensar e agir. (Perrenoud, 2001,p.174)

Perrenoud acredita na mudança do habitus por meio da tomada de consciência, se este for combatido em tempo real e na situação, isto é, se o professor for capaz de, repetidamente, se "surpreender em flagrante delito" e se controlar, novos esquemas, em substituição aos antigos formadores do habitus, podem entrar em ação. No entanto, Perrenoud admite que a tomada de consciência não é um procedimento simples, pois,

Às vezes, em razão de resistências, de angústias, de mecanismos de defesa descritos pela psicanálise, certas atitudes, certas maneiras de fazer em sala de aula são difíceis de reconhecer, porque a tomada de consciência revelaria um passado doloroso, emoções recolhidas, problemas não-resolvidos da infância, da adolescência e da idade adulta.(ibid.,p.172)

Parece-nos interessante que a tomada de consciência, necessária para uma mudança desejável no habitus dos professores, passe então pela investigação mais profunda dessas resistências, angústias e mecanismos de defesa.

Essa investigação, que consideramos promissora, parece avançar os limites da análise de Perrenoud em Pacca \& Villani (2000) e Arruda et al.(2004), em suas pesquisas relativas a programas de formação. Os autores utilizam-se do referencial psicanalítico, incluindo o papel do desejo e da satisfação inconsciente entre os componentes analisáveis dos professores em formação, que podem ajudar na compreensão dos fatores que dificultam o estabelecimento de mudanças em suas práticas. Também preocupados em encontrar procedimentos que levem o professor a estar atento ao que faz e a refletir sobre os resultados da sua prática, já concluíram que 
...não existe uma receita para ensinar o professor a ser reflexivo na ação, pois basta um detalhe para que os resultados sejam diferentes das expectativas. $O$ ponto fundamental é que os ingredientes que chamam a atenção do professor ou despertam sua curiosidade podem não ser suficientes para sustentar o trabalho necessário para que mudanças se estabeleçam. Fatores pessoais parecem ter um peso significativo nesse percurso.(Pacca \& Villani, 2000, p.3)

Perguntamos agora, como seria uma formação que estivesse atenta ao papel do desejo e da satisfação inconsciente nos professores, como propõem os autores, e ainda considerasse a idéia de tomada de consciência desses papéis, de acordo com Perrenoud, visando uma transformação das práticas?

Ainda na vertente da psicanálise, Cifali - sem deixar de lado os aspectos cognitivos e sociais da atividade didática - propõe a reflexividade apoiada numa conduta clínica. A justificativa de uma tal conduta, estaria embutida nas exigências de todos os ofícios que lidam com o ser humano, como é o caso da educação, onde a imprevisibilidade deve ser aceita e impõe limites para a atuação dos sujeitos.

Ser clínico é precisamente partir de algo dado, de expectativas, de referências prévias e, mesmo assim, aceitar ser surpreendido pelo outro, inventar na hora, ter intuição, golpe de vista, simpatia: inteligência e sensibilidade do momento, trabalho na relação, envolvimento transferencial de onde um dia, nesse minuto, nesse acompanhamento, poderá emergir uma palavra ou um gesto que terá efeito, podendo ser apreendida pelo outro, porque ele está pronto para ouvi-la; isto ocorre por força da confiança, de perseverança e sem abandonar a crença nas pulsões da vida quando a destrutividade parece impor-se. (Cifali, 2001, p.106)

Uma formação de acordo com essa conduta, prepara o sujeito para exercer seu ofício munido de uma inteligência clínica.

Somos obrigados a programar, a pensar em fazer isto para obter aquilo, a acreditar em uma lógica da ação em que, se colocamos este ou aquele ingrediente no início, devemos obter este ou aquele resultado $e$, ainda, aceitar que os efeitos previstos nunca sejam exatamente aqueles que advêm em uma relação humana. A seqüência programada de fato encontrará essa variável diferente, e minha lógica de ação será transformada. (...). A ação ultrapassa nossas intenções, como também a palavra.(ibid.,p.106) 
Uma formação desse tipo também implica em considerar a articulação entre os saberes constituídos, os saberes da experiência e os saberes da alteridade. Os primeiros são os saberes de base, aqueles de sua disciplina original, que de modo algum podem ser minimizados, pois ajudam na construção da programação. Os saberes da experiência são aqueles adquiridos na observação do campo onde se tem um envolvimento. Nesse caso, aprende-se a recuperar experiências passadas, sejam elas positivas ou negativas e a refletir sobre elas. Os saberes da alteridade tratam da abordagem dos problemas relacionais; aprender a regular a distância em relação ao outro, sabendo que nossa aproximação ou afastamento, tanto podem the ser benéficos ou infligir-lhe sofrimento.

A conduta clínica a que se refere Cifali, é pautada na singularidade do sujeito (aquele que está diante de mim tem um nome, um sobrenome, uma história) e exige também do formador um espírito clínico. Ao profissional que irá conduzir seu curso, não Ihe bastam os saberes anteriormente mencionados:

É preciso construir mecanismos por meio dos quais o estudante experimente as situações e depois fale delas, compartilhe-as, observe-as em seguida, compreenda sua incompreensão, coloque suas questões, não tenha medo de suas incompetências, aceite seus limites de hoje para construir o saber de amanhã. (Faingold apud Cifali, 2001,p.112)

Ainda no campo da psicanálise, situamos o trabalho de Márcia Bacha em A Arte de Formar (2002), no qual demonstra sua preocupação com os atuais formadores e instituições formadoras, que têm substituído a formação artesanal de homens (Paidéia) pela produção em série de técnicos. Segundo a autora, existe uma demanda explícita (consciente, racional) e uma outra implícita (inconsciente) que é dirigida ao formador. Este, não preparado para lidar com a segunda, lança mão das teorias psi para responder ao professor.

$O$ ofício de formar mobiliza angústias e desejos capazes de convocar um exército de defesas, afastando o formador da imagem de serenidade monolítica de uma tela de projeção, cujo único desafio (do ponto de vista do seu inconsciente) seria o de preparar-se para receber a transferência do ser em formação. (...) Se o conflito é inerente ao seu ofício, reconhecê-lo é uma exigência básica da formação. (Bacha, 2002, p.14) 
Neste trabalho, Bacha questiona seu papel de formadora a partir da prática que exerceu na universidade, com professores, na disciplina de psicologia. Diante de um público heterogêneo que Ihe demandava métodos e receitas mágicas para ensinar, Bacha decidiu que "os professores deveriam falar. Falar de si próprios, sobre os seus ofícios, as suas dificuldades, e não sobre as condições mais do que idealizadas das teorias e das técnicas de aprendizagem e motivação"(ibid.,p.41)

A resistência dos professores ao se verem e a demonstração de angústia frente à formadora, foram suficientes para Bacha atestar que, "além das dificuldades sociais, econômicas, culturais e históricas, a formação do professor tem que enfrentar esse obstáculo de peso que é o inconsciente - do formador, e não apenas do ser em formação" (ibid.,p.64).

Foi ouvindo os professores que Bacha fez "falar os fantasmas que os assombravam", transformando em motor o obstáculo que bloqueava o seu conhecimento. A inquietação da formadora, avessa à adoção de métodos na educação, veio da denominação que posteriormente foi dada ao seu trabalho por seus alunos-professores - por sinal, muito satisfeitos - metodologia da angústia. A pergunta que ela se coloca: "O que foi que eu fiz?", nos é indício do efeito surpreendente que ela causou, não só nos professores, mas nela mesma, mostrando que também vivenciou com seus alunos - se é que podemos chamar assim - uma experiência que se aproxima de uma análise.

A partir da proposta de Cifali e Bacha, que evidenciaram-nos o papel do formador e os efeitos de suas intervenções nos professores em formação, lançamos as seguintes perguntas em nossa pesquisa: de quais competências deverá se dispor o formador, para exercitar a "formação artesanal de homens", admitindo a singularidade dos professores em formação? Em outras palavras, não poderiam os formadores orientar os professores para uma reflexão mais profunda e subjetiva, visando atingir o sujeito da prática, questionando-o - "como você se sente fazendo isso? por que você faz desse jeito? por que você quer fazer isso?" - de modo a tornar mais satisfatória a prática do sujeito?

Em Aquino (2001), encontramos os resultados de uma pesquisa a cerca das práticas de professores em serviço, analisadas segundo o aporte teórico- 
metodológico da Psicologia Institucional. Dentro desse aporte, o cotidiano de um grupo de professores foi investigado e analisado pelo crivo específico dos conceitos de instituição e subjetividade. Em outro trabalho, Aquino articula esses conceitos à noção de sujeito-de-lugar.

O sujeito (...) só pode ser pensado na medida em que pode ser situado num complexo de lugares e relações concretas (relações sempre institucionalizadas, portanto). A noção de sujeito psicológico passa a implicar, dessa forma, o lugar institucional a partir do qual pode ser regionalizado no mundo (sujeito sempre institucional, portanto). Sujeito que só o é, de fato, como efeito de uma equação institucional que requer obrigatoriamente um outro complementar (uma relação pontual, portanto). E sendo assim, que ocupa um lugar determinado em relação a outrem (parceiro de uma relação institucionalizada, portanto). E que o faz sempre de modo singular. Ou seja, está inserido em uma relação, ocupa um lugar determinado nessa relação, e dele se apodera segundo uma maneira específica, isto é, uma posição. (Aquino, 2000,p.18)

Entendido assim, o professor é convidado a refletir, não mais sob a égide do modelo corretivo de formação gerido pela razão científica, a partir de situações pontuais de sala de aula, mas sobre o lugar do professor no cenário escolar da atualidade. Nesse formato, o professor indaga-se mais fortemente e mais para além dos objetos de reflexão que objetivamente lhes são propostos.

Esse novo formato incita o professor à adoção de um conjunto de condutas que o dispensa de ser um agente de repetição de modelos préfabricados para lançá-lo na perscrutação de si mesmo. Uma nova ordem de codificação coloca-se para o pensar-se professor. Um novo modo de "saber de si" no fulcro da prática formativa é então disparado e conferido ao professor.(ibid.,p.225)

A partir de Aquino, que nos mostra o professor como um sujeito-de-lugar, isto é, que, inserido num lugar, ocupa uma posição e que, a partir dela, procura "saber de si”, também perguntamos em nossa pesquisa: que efeitos teria uma formação na qual, não apenas o professor, mas também o formador pudesse ter "sapiência de si”, ou seja, das próprias posições que ocupa? E se essas posições não fossem apenas entendidas como tomadas em função de relações institucionalizadas sendo estas delimitadas pelo pensamento e pela ação racional e consciente dos 
sujeitos - mas também tomadas pelo resultado de um assujeitamento ao plano inconsciente?

O que buscamos neste trabalho é que, partindo da idéia de uma formação reflexiva na linha da subjetividade, considerando e, ao mesmo tempo, indo um pouco mais além das proposições dos autores mencionados, possamos responder às questões que lançamos anteriormente, quiçá sugerindo novas hipóteses para pensar a formação de professores.

\section{O PAPEL DO FORMADOR NA FORMAÇÃO DE PROFESSORES E DO ANALISTA NA ANÁLISE: ANALOGIAS POSSÍVEIS}

Dewey nos coloca que o pensar reflexivo abrange duas fases que 0 caracterizam como tal: "1) um estado de dúvida, hesitação, perplexidade, dificuldade mental, o qual origina o ato de pensar; e 2) um ato de pesquisa, procura, inquirição, para encontrar material que resolva a dúvida, assente e esclareça a perplexidade"(Dewey,1959.p.22).

Entendemos que, para Dewey, o processo reflexivo pressupõe: um estado específico e anterior de coisas, que inaugura o pensar, e um estado posterior, do próprio ato em si de pensar. Apresentar o mecanismo dessa forma "simplificada", não significa, em absoluto, que estamos a julgar o ato como elementar. Dewey nos mostrou toda a complexidade que envolve o ato de pensar e ao dialogar com ele, a partir do referencial psicanalítico, só fizemos ampliá-lo, acrescentando e ressignificando alguns de seus elementos. Contudo, parece-nos que essas duas fases do pensamento reflexivo são percorridas solitariamente, pois envolvem, num primeiro momento, um indivíduo perplexo diante de uma situação-problema e o mesmo indivíduo, num segundo momento, às voltas com seu pensamento, a buscar soluções. Acreditamos que a passagem do indivíduo por essas fases, deva ser assistida por um interlocutor, isto é, acompanhada de um outro que o auxilie nessa 
travessia. No contexto da formação de professores, esse apoio deve vir do formador, o que equivale, em situação de análise, ao papel do analista.

Tentaremos então fazer um paralelo - nos termos que forem possíveis e salvaguardando as especificidades de cada um - entre o papel do formador de professores e o papel do analista.

O interlocutor fará o papel daquele que ouve o sujeito, pressupondo portanto, que este último se dirija ao primeiro por meio de sua fala. A fala, na psicanálise, é o meio de expressão do conteúdo inconsciente que, ao contrário do que se pensa, está na superfície - o inconsciente só está escondido na medida em que não é formulado e não se desenrolam seus significantes. A partir desta hipótese, Freud cria uma técnica que tem uma única regra, "a regra de ouro da psicanálise": a associação livre. $\mathrm{Na}$ articulação das palavras, o sujeito vai criando relações com um número cada vez maior de significantes, vai fazendo aparecer os significantes recalcados, veiculadores de cenas onde se manifesta o desejo.

No momento em que se fala, o sujeito experimenta o peso e o valor das suas palavras e muitas vezes acontece dele procurar se corrigir. É o Outro quem fala por ele. E "a essa particularidade de o sujeito se ouvir quando ele mesmo fala e ao se ouvir se dividir, pois, por vezes, fala coisas que não queria, que não sabia (que sabia) e que o surpreendem como se fosse a fala de outrem. E também quando não escuta o que fala, principalmente quando é algo que ele não queria falar e, sem querer, fala" (Quinet,2000,p.44).

No caso de uma situação de análise, é para o analista que o sujeito dirige sua fala, presentifica seu inconsciente, isto é, o faz existir. O analista ocupa portanto, lugares onde o sujeito o coloca e com isso faz funcionar o processo da análise. Um desses lugares, o de Sujeito Suposto Saber, significa que o analisando supõe no analista a pessoa que detém todo o saber sobre o seu sofrimento, sintoma, fantasias, desejos, quando na verdade, o analista só pode saber o que será construído na análise. A relação que se estabelece entre a posição do analista e a do analisando é constitutiva da análise e dá-se o nome de transferência, como já o dissemos. Na fase de transferência, o analista ocupa o lugar do Outro, um lugar 
simbólico, onde ele representa para o sujeito todos os Outros da sua vida, levando assim o sujeito a confrontá-los.

Além do lugar determinado pelo analisando para o analista, este último deve assumir responsabilidades e disposições por sua posição, já que é ele quem conduz o tratamento. Cabe ao analista preparar-se para uma escuta sem preconceitos, desarmada, exposta aos efeitos do inconsciente. Essa escuta recebe o nome de atenção flutuante. Freud formula essa técnica explicitamente em "Recomendações aos Médicos que Exercem a Psicanálise" (1912), da seguinte maneira: "Consiste simplesmente em não dirigir o reparo para algo específico e em manter a mesma 'atenção uniformemente suspensa' em face de tudo o que se escuta". Ao mesmo tempo em que o analista deve estar atento a tudo que aparece na superfície psíquica do seu paciente, ele deve ficar aberto ao inesperado, estar pronto para deixar-se surpreender.

Se é para o analista que o analisando se dirige, é o seu comportamento técnico que vai evocar no sujeito o desejo de falar, ou seja, vai provocar-lhe demandas. $\mathrm{O}$ analisando espera que o analista lhe dê o que o analisando Ihe atribui e supõe que ele possui, ou seja, o falo. Se o analista ocupar a posição de falo imaginário, despertará no analisando a condição para que ele fale, se engane, na expectativa de que receba dele esse objeto.

Não é apenas o analista que deve estar preparado para surpreender-se com a fala do sujeito, mas ele próprio deve ser capaz de surpreender o sujeito e arrancarIhe manifestações do tipo: "Nunca tinha pensado nisso". Esse é o momento em que o analista intervém fazendo a interpretação, no qual tem a chance de perturbar o sujeito, abalar suas estruturas, incitá-lo à reflexão profunda.

Já dissemos sobre a importância do analista em sustentar-se como ser de desejo diante do analisando. Isso não significa o analista "moldar o desejo do analisando em seu próprio, mas abalar a configuração da fantasia do analisando, mudando a relação do sujeito com a causa do desejo: o objeto a" (Fink,1999,p.85) .

Obviamente que não estamos tentando transformar formadores em analistas, mas cogitando a exploração, pelos formadores, das técnicas da análise associação livre, atenção flutuante e intervenções interpretativas - no processo de 
formação de professores. Mas talvez, mais do que a técnica, é a postura do analista diante do paciente, que constituir-se-á fator de primordial importância no estabelecimento das relações intersubjetivas a partir das quais se obterá o efeito da análise. Conclui-se, portanto, que, tal qual a postura do analista, é a postura do formador diante dos professores, que também pretende-se subjetivar no trabalho de formação, principalmente quando este trabalho se propõe levar a cabo uma prática reflexiva.

Monteiro(2005), em sua tese de doutorado "Sobre uma especificidade do ensino da psicanálise na universidade: a formação de educadores", assinala as contribuições da psicanálise para a educação, declarando que a necessidade de uma postura reflexiva sobre a tarefa educativa não deve ser confundida com a proposta reflexiva da "Pedagogia Científica".

A reflexão proposta pela psicanálise supõe que o professor faça uma res-significação de sua atuação junto aos alunos. Isto implica em redimensionar as metas idealizadas que tentam inspirar o ato educativo na atualidade e que, diferente da "retrógrada" intenção de atingir um ideal humano, visa uma adequação científica animada por teorias psicológicas e aportes tecnológicos. (Monteiro,2005,p.158)

Embora Monteiro dirija sua tese para o processo da formação do professor enquanto agente focado em suas metas educativas em relação à criança, podemos tranqüilamente transpô-la para o contexto da formação do professor, sublinhando o papel e o lugar do formador na relação com os professores-alunos. $O$ trecho abaixo representa bem um exemplo no qual se pode ler educador como formador, e professor no lugar de criança:

Os desejos e fantasias do educador afetam a ação educativa. Seu narcisismo pode levá-lo a não resistir à tentação de pretender modelar a criança em função de seus próprios ideais e, assim, a criança passa a ocupar o lugar do seu desejo. Reconhecida na mesma proporção em que é destituída de si mesma, cabe à criança apenas o lugar de alienação.(ibid.,p.148)

Monteiro não abraça necessariamente a idéia de que educadores saibam psicanálise para ensinar bem, mas valida que o conhecimento desta pelos 
professores, abra a possibilidade para que uma educação leve em conta o sujeito do inconsciente. Como anteriormente, podemos fazer a transposição neste trecho:

...levando em conta o sujeito, o educador saberá que, apesar das marcas e da determinação das inscrições primordiais, a aprendizagem do aluno não está predeterminada em limites, direção, tempo e meios. Logo tomará para si a responsabilidade por seus atos educativos e, possivelmente, fará diminuir o número de encaminhamentos a especialistas, como os do campo psi..(ibid.,p.164)

Podemos então, dizer que seria conveniente que os professores se submetessem a uma análise? Sobre esta questão, Kupfer (2000) nos fala sobre como entende que o conhecimento da psicanálise pode ser útil aos educadores.

Há uma transmissão da psicanálise ao educador, além daquela que poderia ser feita no divã. Atestam-nos os efeitos que se produzem quando os educadores se põem a estudar psicanálise; efeitos que podem ser de angústia, de atuação, defensivos. Não aqueles esperados por um analista - a travessia do fantasma, a passagem pelo Rubicão, que transforma radicalmente. Ainda assim, efeitos. (Kupfer,2000,p.119)

Em nosso trabalho, transformamos a afirmação de Monteiro para os professores, em questionamento para o formador: que desejos e fantasias do formador afetam sua ação educativa? E ainda, seria possível ao formador adotar técnicas análogas ao do analista em relação aos seus professores-alunos, sem antes passar pelo questionamento de suas próprias posições subjetivas diante do(s) Outro(s), do seu gozo e do seu desejo? 


\section{CAPÍTULO II}

\section{METODOLOGIA DA PESQUISA}

O presente trabalho de pesquisa aproxima-se, em seus aspectos principais, do campo epistêmico e metodológico da linha de pesquisa que é desenvolvida por nosso grupo ${ }^{3}$ (Villani et al, 2006), desde meados da década de 90. Essa linha privilegia o estudo da dimensão subjetiva envolvida nos sujeitos ou grupos frente ao ensino, à aprendizagem e ao conhecimento científico. É atuando na perspectiva de que o inconsciente permeia as situações de ensino/aprendizagem, que elementos do referencial teórico psicanalítico (Freud, Lacan, Bion, Anzieu, Kaës, Winnicott) vêm sendo explorado e revelando-nos seu potencial de análise.

A metodologia de pesquisa do grupo conta com elementos e procedimentos que explicitaremos a seguir, ao mesmo tempo em que iremos expondo o caso específico deste trabalho.

\section{A escolha dos casos}

Os casos escolhidos são aqueles nos quais a possibilidade de explorar o referencial psicanalítico se revela mais promissora. São cenas ou situações de sala de aula que dão indícios de eventos repetitivos ou de alguma maneira perturbadores, onde a ordem das coisas propõe uma "novidade" que vale a pena ser investigada, com chances de produzir um conhecimento novo.

Nesta pesquisa, nos propomos a uma investigação dos cursos de formação continuada de professores de ciências, visando o trabalho do formador. O formador

\footnotetext{
${ }^{3}$ O grupo envolvido de maneira estável com o referencial da psicanálise é formado pelos doutores: A. Villani (coordenador), E. Barolli, S.M. Arruda, M.A. Barros, M. Franzoni e alguns de seus respectivos orientandos. Têm colaborado sistematicamente também as doutoras T.C.B. Cabral, J.L. Pacca e D. Freitas. A responsabilidade da metodologia do grupo é dos autores.
} 
como nosso sujeito e seu modo de lidar com os impasses na educação de professores em serviço, nosso objeto de pesquisa.

O contexto nos parece relevante, na medida em que uma prática reflexiva, como tem sido abordada nos cursos de formação, leva em conta apenas a dimensão objetiva e racional do processo e exclui os fenômenos do inconsciente. Desse modo, em nossa concepção, as ações do formador com pretensão de favorecer mudanças nas práticas docentes, podem ser questionadas em suas limitações, já que desconsideram que elementos do inconsciente, tanto dos professores como do próprio formador, estejam atuando. Daí, a situação que se repete é aquela que gira em torno das mudanças insuficientes das práticas docentes e, conseqüentemente, do ensino que é levado à sala de aula e das justificativas - sempre levadas ao nível racional - que se apresentam para tais resultados. Sem contar com o sentimento de frustração que muitas vezes é gerado nos formadores e nos professores em formação.

Nossa investigação se inicia num curso de formação continuada para professores de química, que acompanhamos durante o ano de 2004, na Faculdade de Educação de uma Universidade Paulista. Sob a regência de uma formadora iniciante, Malu, o curso se apóia na proposta de reflexão sobre a prática da sala de aula de um grupo de professores. A troca de idéias, que acontecia nos intervalos entre os encontros para discutirmos o planejamento das atividades, foi suficiente para que eu percebesse os contrastes entre as suas reflexões e suas ações diante do grupo.

A hipótese de que a posição subjetiva da formadora frente aos impasses de sua tarefa e frente aos outros sujeitos (eu, seu orientador, a Academia, o grupo de professores) envolvidos na situação, estivesse interferindo nas ações da formadora e nos resultados obtidos, nos acenava com a possibilidade de um avanço em termos da exploração de aspectos de natureza subjetiva, que influenciavam naquela situação. $E$ isso nos levou a investigar também a experiência de outros formadores: Nil, Ronaldo, Jerusa e a minha, inclusive. 


\section{0 registro dos dados}

Apoiando-se nos procedimentos usuais da pesquisa qualitativa, nosso grupo tenta se aproximar do que considera ideal em termos de registro de dados. Um detalhamento maior dos registros possibilita uma interpretação à altura requerida pelo referencial psicanalítico. Desse modo, as melhores condições para o registro acontecem nas seguintes circunstâncias:

a) O responsável pelo evento é um dos pesquisadores; desse modo obtém-se informações tanto objetivas quanto subjetivas sobre os casos pesquisados. No caso do curso na Faculdade de Educação, participei como responsável pelo evento e pesquisadora da minha própria prática, nos momentos da condução de dois dos encontros. A formadora Malu, que conduziu a maior parte do curso, teve sua experiência acompanhada por mim em todos os encontros, inclusive contando com a minha colaboração no planejamento das atividades. No caso do curso do formador Nil, participei apenas como pesquisadora, ausente em alguns encontros. No caso dos formadores Ronaldo e Jerusa, embora no papel de pesquisadora, não houve acompanhamento em seus cursos.

b) $\mathrm{O}$ registro eletrônico fornece dados mais precisos. Nos momentos dos encontros, quando da coleta dos dados de minha experiência, de Malu e de Nil foram feitas através de gravações em áudio e vídeo, contando com o auxílio de um técnico de som e imagem, para minimizar as perdas de qualidade do material. Fora dos encontros, todas as entrevistas realizadas com os formadores foram gravadas em áudio.

c) O registro escrito proporciona informações suplementares, sobretudo sobre a qualidade do trabalho desenvolvido pelos participantes do evento. Para a análise da minha experiência, de Malu e de Nil, ainda contamos com respostas escritas dos professores a questionários e auto-avaliações.

Nosso grupo considerou que os registros mais abrangentes e com possibilidade de maior articulação dos dados se encontrariam nos casos da pesquisadora e de Malu. No caso de Nil, minha ausência em parte dos encontros deveu-se a dois motivos: meu contato com os formadores ocorreu depois do primeiro encontro do grupo e a data do último encontro coincidiu com compromissos 
de trabalho. No caso de Ronaldo, no momento da entrevista ele não estava ministrando nenhum curso de formação do qual pudesse participar. Por último, Jerusa foi procurada e entrevistada quando já se encontrava na fase final de um dos seus cursos.

\section{A análise dos dados}

A análise dos dados conta com: o material contido nos registros escritos e eletrônicos, somado às impressões subjetivas dos sujeitos pesquisados e às lembranças remotas do pesquisador (não registradas de forma sistemática); o referencial teórico que articula os conceitos da psicanálise à história dos eventos ocorridos; as contribuições de um grupo de pesquisadores, que colaboram com questões, interpretações e hipóteses sobre a dinâmica dos eventos e a atuação do pesquisador.

Cada caso analisado representa uma história particular, onde cada sujeito apresenta sua conduta específica, de modo que os recortes realizados em cada uma ressaltam determinadas singularidades, aquelas que, subjetivamente, nos interessaram. Sendo assim, cada caso vai encontrar sua ressonância particular no interior do vasto referencial psicanalítico.

Em nosso trabalho, estando o foco da análise dirigida à pessoa do formador, individualmente, e não ao grupo de professores, a analogia mais conveniente com a psicanálise nos converge para os teóricos voltados ao processo individual de análise. Assim, recorremos às teorias de S. Freud e J. Lacan e de seus intérpretes B. Fink, A. Quinet, J. D. Nasio entre outros, e excluímos os teóricos preocupados com desenvolvimento e organizações grupais como W. Bion e R. Kaës. Não pudemos deixar de lado autores que fazem a conexão entre educação e psicanálise (M. C. Kupfer, L. Mrech, L. de Lajonquière e outros) ou que incorporam o papel da subjetividade e sua possível influência nos processos de ensino e aprendizagem das ciências (B. Charlot, A.Villani, J. Pacca e outros) e demais membros do nosso grupo.

Ao longo da reconstrução das histórias, aparecem as falas dos sujeitos acompanhadas, primeiramente, dos comentários mais objetivos que dão sentido aos eventos. Depois, uma reflexão mais profunda tenta captar a essência de cada 
história, explorando as hipóteses mais prováveis que ajudariam a explicar e compreender melhor a posição subjetiva de cada sujeito, utilizando-se então os conceitos psicanalíticos que nos permitem interpretá-los.

Uma característica da dinâmica de funcionamento do nosso grupo de pesquisadores, que não participaram das experiências analisadas, consiste em levantar algumas questões com a intenção de evidenciar elementos menos conscientes na condução e na interpretação dos dados. Essa função do grupo tem possibilitado ao pesquisador que expõe seu trabalho, falar em "livre associação". O resultado disso é que o pesquisador pode se utilizar, a-posteriori, dos elementos que emergiram para reavaliar sua posição subjetiva frente aos dados, fazer novos questionamentos, reorientar ou complementar suas interpretações. Essa dinâmica tem também uma função perturbadora, pois abala certas convicções e, em alguns pesquisadores, pode despertar suas resistências. Nesses casos, se o pesquisador conseguir sustentar o desconforto do momento, terá a oportunidade de analisá-las, considerar as críticas como positivas e explorar as sugestões do grupo.

Um exemplo disso, foi a possibilidade de fazer um enfrentamento de questões perturbadoras que surgiram durante a análise da minha própria experiência como formadora. Aceitar as críticas do grupo, na medida em que me exigiu um trabalho de superação de resistências, contribuiu significativamente para o amadurecimento da minha pesquisa, e porque não dizer, também para o meu crescimento pessoal.

As palavras finais do texto do grupo sobre metodologia de pesquisa, retratam de forma sintética, o caminho percorrido durante a elaboração da tese:

A nossa metodologia define-se, assim, em perseguir algumas questões. Em primeiro, a totalidade e uma explicação exaustiva da situação relatada, na medida do possível. A importância do grupo de pesquisadores é fundamental nesse momento, devido ao distanciamento e a capacidade de inserir os dados em um amplo leque de hipóteses. A seguir, com ajuda do referencial teórico, buscamos a consistência dos modelos interpretativos. Se não negligenciamos determinados aspectos, que normalmente poderiam ser marginalizados - em parte pelas mudanças das perguntas iniciais -, acreditamos que a interpretação é ampliada e temos como resultado uma maior consistência. Por último, a capacidade de discriminação que implica em buscar, dentro de determinados relatos e práticas implementadas, a seleção de dados 
pertinentes com as questões propostas. Ao mesmo tempo, no desenrolar da análise, o trabalho em grupo propicia saber"a estabilidade $e$ proximidade" da interpretação com os dados coletados e esse padrão define uma interpretação mais válida.

Em nossa opinião, o resultado concreto mais valioso desse questionamento, em geral, é a mudança de visão que os pesquisadores alcançam sobre sua experiência, com reflexos importantes na prática sucessiva. Perceber uma diferente relação com o conhecimento em jogo e com os outros participantes pode ser o primeiro passo de uma mudança de posição nas novas situações. Em geral, nossa prática investigativa tem produzido resultados cujos desdobramentos na sala de aula contribuem para aumentar a sensibilidade do docente, seja no que se refere à escuta do aluno, seja no que se refere a seu próprio processo reflexivo. Cabe ainda mencionar o valor potencialmente heurístico de alguns conceitos, cuja aplicabilidade tem se mostrado frutífera em um grande número de situações, apesar de todas as dificuldades. Por exemplo, a utilização do conceito de intermediário, para articular as mudanças na sala de aula, e de economia do gozo, para interpretar seus impasses, têm ultrapassado o campo da pesquisa para orientar intervenções docentes; o discurso do professor tem realizado a síntese da relação entre docente e conhecimento com os efeitos produzidos nos alunos. (Villani et al.,.2006,p.385-386) 


\section{CAPÍTULO III}

\section{ANÁLISE DOS DADOS}

Pode-se dizer que, diferentemente da pedagogia e da psicologia, a psicanálise revela que a transmissão do saber não é isenta. Nós sempre nos posicionamos de alguma forma frente a ele, mesmo que seja a partir da posição de objeto. (Mrech, 2002)

\section{A EXPERIÊNCIA DA PESQUISADORA NO PAPEL DE FORMADORA}

\section{Sobre meu envolvimento num curso de formação continuada}

Desde o mestrado, no princípio do meu envolvimento com as questões subjetivas ligadas às práticas docentes - particularmente as que levam em conta a dimensão do inconsciente -, venho investigando as possíveis articulações entre as teorias psicanalíticas e a formação de profissionais da educação. Na época, analisei, sob a luz de conceitos da psicanálise, os conflitos que alguns professores de ciências trouxeram para o interior de um curso de formação, do qual participei apenas como observadora. Esses conflitos apareceram sob a forma de queixas, nas quais se percebeu que "a realidade" do curso, descrita pelos sujeitos como idealizada, estaria muito distante da "realidade" de suas salas de aula. Terminei a dissertação concluindo que os diferentes conceitos e percepções que os 
professores tinham acerca da "realidade", assim como as posições por eles assumidas diante dela, acabavam por interferir na realização de mudanças efetivas na prática desses docentes.

Inspirada pelas conclusões geradas na pesquisa de mestrado e pelas contribuições positivas que o referencial teórico da psicanálise vem oferecendo para os autores que a reconhecem e a utilizam - na análise das questões da educação, vislumbrei a possibilidade de aproximar a técnica analítica do trabalho de formação de professores. Inicialmente, a idéia era que, utilizando alguns elementos da técnica analítica - a escuta especial, a atenção flutuante, a livre associação e intervenções interpretativas - fosse possível levar os professores em formação a questionarem mais profundamente sua prática. Neste caso, a finalidade do diálogo entre a técnica analítica e a educação de professores seria a de amenizar conflitos e elevar o nível de satisfação dos docentes em relação à sua prática.

Quando aceitei o convite para uma co-participação no curso de formação continuada "Encontros de Reflexão e Ação sobre a Sala de Aula de Química", numa universidade pública, o fiz com a intenção de coletar dados para minha pesquisa de doutorado, mesmo ainda sem uma definição clara do problema que iria investigar. Junto a essa expectativa, havia um grande desejo de realizar um trabalho cujos resultados agregassem contribuições relevantes para a Academia, servindo como referência para outros autores e pesquisadores.

Devo admitir também que esse convite não era academicamente atrativo apenas no tocante à elaboração do meu trabalho de pesquisa. Ele significava a chance que eu esperava ter, dentro da universidade, de passar para "o outro lado da mesa", onde eu julgava que só poderia estar uma minoria privilegiada. Enfim, nesse convite havia uma conotação de valoração pessoal, de reconhecimento da minha capacidade profissional, como se ele significasse uma autorização, um aval para a ocupação de um lugar especial. Queria aproveitar a oportunidade para atuar também como formadora.

O curso de formação teve não só o propósito de iniciar uma parceria entre a universidade e os professores de química da escola pública mas - só quase ao seu 
final vim a saber - fora idealizado também para fornecer subsídios para a pesquisa de mestrado de Malu.

Malu era mestranda pela Faculdade de Educação dessa mesma Universidade Paulista onde se deu o curso e o nosso primeiro contato. Ela me foi apresentada por seu orientador, professor de Prática de Ensino de Química da faculdade, por quem fui convidada e para quem já havia prestado serviço de monitoria, pela mesma disciplina, no semestre anterior. Antes da primeira reunião de planejamento, Malu já possuía a lista de professores inscritos.

Foi com plena satisfação que participei do planejamento inicial do curso, junto com Malu e seu orientador. Malu me parecia firme e determinada, ao passo em que eu me encontrava eufórica mas um pouco apreensiva diante da responsabilidade da tarefa. Ajudei Malu na seleção do material didático (textos e vídeos) e na elaboração de atividades para os professores.

Quando o curso iniciou, Malu parecia muito à vontade com os professores, conduzindo as atividades num clima de descontração e leveza. Ela parecia ter o controle da situação, mostrando segurança em suas ações. Quanto a mim, preferi uma aproximação gradativa e cuidadosa. Nos primeiros encontros, estava preocupada em capturar dados para a minha pesquisa e na maior parte do tempo, me esforçava em fazer anotações das falas dos professores, buscando encontrar nelas elementos que pudessem estar relacionados com a subjetividade deles, tais como resistências, medos, angústias, desejos e o modo de enfrentar seus conflitos e impasses, conforme minhas intenções anteriores.

Sentia que, nas poucas vezes em que participava das atividades, os professores me acolhiam e ficavam atentos aos comentários que eu fazia durante as discussões ou no atendimento que Ihes prestava durante os trabalhos. A impressão era que os professores sentiam que eu tinha algo muito importante a acrescentar naqueles momentos. Alguns professores me procuravam no final dos encontros para prolongar alguma discussão, tirar dúvidas ou pedir sugestões. Eu sentia satisfação em ajudá-los, ora ouvindo suas queixas, ora questionando-os acerca de suas posições diante dos conflitos que eles traziam até mim. 
Contudo, havia, de minha parte, um sentimento de desconforto, que me deixava pouco à vontade para contribuir com intervenções. Primeiramente, penso que, pelo fato de Malu assumir a regência do curso, eu tivesse receio de roubar-lhe as atenções, de ser inconveniente. Por sua vez, Malu dava demonstrações de abertura ao diálogo, permitia que um clima de parceria se instaurasse de forma crescente a cada novo contato. De fato, sentia em relação a ela uma proximidade progressivamente maior ao longo do ano, que se concretizava, por exemplo, nas discussões abertas que fazíamos a respeito dos eventos ocorridos a cada encontro com os professores, muitas vezes compartilhando nossas próprias dificuldades. Isto, porém, não significou que o sentimento de desconforto tivesse deixado de me acompanhar.

Em segundo lugar, apesar da satisfação que sentia no atendimento aos professores e da agradável receptividade que demonstravam, também havia desconforto em lidar com esta posição. Comecei a perceber que era mais difícil estar diante de colegas de profissão do que diante dos meus alunos do nível médio. Não me sentia em condições de sustentar uma posição diferenciada em relação a eles, como estava acostumada ao longo da minha atuação como professora de química.

\section{O giro nas intenções primeiras da pesquisa: a formadora como sujeito}

Ao longo dos encontros, percebi que para penetrar no mundo subjetivo daqueles sujeitos, como inicialmente eu pretendia, não poderia permanecer recuada, coadjuvante naquele cenário. A escuta dos professores e as minhas intervenções pontuais já não me bastavam. Precisava encontrar uma maneira de me aproximar mais do grupo, de interagir com os professores. Isso significava que, em algum momento, eu haveria de tomar o lugar de Malu como formadora e assumir a posição que eu muito desejava.

Era a hora de enfrentar a situação que se apresentava diante de mim, e isso significava ter que lidar com meus próprios medos, resistências, inseguranças e desejos. Os relatos que se seguirão mostram, com detalhes, como se deu esse enfrentamento, ou seja, mostram como aqueles aspectos subjetivos, que eu 
pretendia inicialmente observar nos professores em formação, passaram a ter importância na minha atuação como formadora.

Sair detrás das cortinas e passar à frente do palco, nesse caso, implicava em ser sujeito duplamente: ser sujeito na pesquisa, enquanto tentava fazer valer meus propósitos como formadora e pesquisadora e ser sujeito da pesquisa, enquanto protagonista da minha própria investigação.

Para revelar esse duplo sujeito, tive que contar com a ajuda de espelhos, cujas imagens me refletem, me dizem como me apresento ao mundo. Para a Psicanálise, o espelho seria o grande Outro, um corpo organizado, possuidor das linhas mestras de um ideal, de um determinado padrão, através do qual ele mede o mundo (Forbes, 1999,I). Por outro lado, esse espelho também pode significar o pequeno outro, o semelhante com o qual me encontro muitas vezes identificada.

Pratiquei esse exercício mirando principalmente as imagens de Malu e do grupo de professores. A Academia também aparece como uma referência implícita, que, em certos momentos, me orienta ou me faz inquirir sobre minha forma de conduta. Sendo assim, foram esses os Outros e outros, primordiais, que puderam desempenhar o papel de espelhos, refletindo, medindo e avaliando minhas imagens de formadora e pesquisadora.

Mas esses espelhos não são espelhos passivos, daqueles que você olha e ele Ihe devolve a sua imagem. São espelhos com os quais eu interajo, estabeleço relações imaginárias, simbólicas e reais. A partir dessas relações, sustentarei a hipótese de que as posições subjetivas nas quais me encontrava em relação ao grupo de professores, a Malu e à Academia, possam explicar as ações e questionamentos que estão envolvidos nos eventos que serão relatados.

O relato que se segue, como já afirmei, é sobre eventos que sucederam durante a minha intervenção no curso de formação, nos quais minhas posições subjetivas são trazidas a termo e analisadas à luz dos conceitos fundamentais da Psicanálise. Não se tratará de uma análise nos moldes da técnica psicanalítica, mas uma discussão que, sobretudo, levantará questões sobre o ser formador, numa dimensão mais profunda do que aquela praticada segundo os modelos da reflexãosobre-a-ação e do professor reflexivo. 
Portanto, ao me propor a penetrar no mundo particular dos sujeitos, que compreende suas angústias, resistências, medos, satisfações e desejos, não poderia analisar apenas o sujeito como o conceituou Descartes - da razão consciente, do "penso, logo existo". Esta é uma proposta na qual se baseiam os modelos da reflexão-ação e do professor reflexivo.

O que se levará em conta é o sujeito concebido por Lacan - o sujeito da razão inconsciente, do "desejo, logo existo" - que é habitado pela dúvida, pela hesitação. Propõe-se aqui um trabalho de cunho perturbador que, se levado a cabo em cursos de formação, estimularia o professor a se questionar a partir de sua especificidade, de sua singularidade, lá onde residem suas certezas.

\section{A experiência de conduzir os encontros: uma intervenção (in)conscientemente programada}

Naquele primeiro semestre, paralelamente ao curso de formação, eu freqüentava a disciplina de pós-graduação "O Discurso do Inconsciente nas Manifestações do Oral e suas Possibilidades Pedagógicas". Aproveitando a abordagem central da disciplina - a linguagem oral como via de manifestação dos desejos inconscientes -, surgiu a idéia de criar um momento especial nos encontros de formação, para extrair alguns dados que pudessem ser aproveitados na elaboração da monografia exigida ao final do semestre.

A idéia de abordar o tema "A Linguagem nas Aulas de Ciências", nasceu então da necessidade de conciliar a elaboração da monografia, o estabelecimento de um vínculo maior com o grupo de professores, a coleta de dados para minha pesquisa e o desejo de assumir o lugar de formadora. A meu favor, não podia contar com melhores condições: a adequação do tema escolhido, perante os objetivos do curso. O apoio de Malu, diante da idéia, e as demonstrações de acolhida por parte do grupo me deram liberdade suficiente para conduzir as atividades.

O tema escolhido - a preocupação com o papel e o uso da linguagem científica, principalmente no que se refere à construção de conceitos - é bastante familiar para os professores da área, sendo esse um dos mais recorrentes nas pesquisas sobre ensino/aprendizagem de ciências (Machado \& Moura,1995; 
Schnetzler \& Aragão, 1995; Mortimer \& Machado,1996; Silva \& Schnetzler, 2000; Machado, 2000; Mortimer, 2002 - para citar apenas o ensino de química).

Aproveitando a familiaridade do tema, porém tentando escapar da dimensão em torno do qual ele é comumente tratado - a dimensão cognitiva - tanto nos cursos de formação, quanto nas pesquisas acadêmicas, minha preocupação era assegurar que os professores falassem espontaneamente. Numa analogia à técnica psicanalítica, essa fala espontânea dos sujeitos, corresponderia à livre associação, isto é, "quando o paciente deve exprimir todos os seus pensamentos, idéias, imagens e emoções, tais como se apresentam a ele, sem seleção e restrição, mesmo que tais materiais Ihe pareçam incoerentes, impudicos, impertinentes ou desprovidos de interesse" (Chemama, 2002,p.22).

Outra preocupação era perceber, nas falas dos professores, algo que demonstrasse suas concepções arraigadas, estereótipos, pontos de solidificação em suas práticas. Captar essas informações constitui, por si, uma tarefa bastante complexa, pois requer do ouvinte uma escuta especial, particular. Analogamente à técnica analítica, eu deveria permanecer em atenção flutuante que "pressupõe, da parte do praticante, a supressão momentânea de seus pré-julgamentos conscientes e de suas defesas inconscientes" (Chemama,2002,p.22). Já havia tentado algo semelhante realizando as entrevistas individuais no mestrado, mas nunca durante a efervescência de uma discussão em grupo.

Se uma conduta desse tipo já comporta uma certa ousadia, maior tensão estaria localizada no momento de ajudar os professores a se perceberem em suas próprias falas, isto é, a se questionarem, por exemplo, a respeito das suas concepções prévias, principalmente aquelas que os manteriam presos a repetições, promovendo resultados insatisfatórios em suas práticas.

Evidentemente, embora não se trate de uma situação de análise, quando o propósito é levar os professores a um questionamento que abale suas zonas de segurança, seria apropriado que houvesse a realização de intervenções adequadas por parte do formador. Numa situação analítica, isso equivaleria ao que Lacan chamou de retificação subjetiva. Quando o paciente expõe sua queixa, "depende de nossa maneira de escutá-lo, de nossa maneira de intervir ou de fazer 
perguntas, para que ele comece a perceber um outro modo de viver o seu sofrimento, uma outra maneira de manifestar a sua demanda de cura" (Nasio, 1999,p.162)

Uma intervenção adequada, em uma situação de análise, é o que se chama interpretação. Nesse momento, o analista surpreende o analisando por meio da colocação de uma pequena frase, palavra ou gesto em momento oportuno. O sinal do impacto da interpretação no analisando é o seu silêncio, precedido de um "choque", causado por uma verdade que vem à tona subitamente, que é escancarada ao analisando. O efeito disso é profundo e age ao nível de sua estrutura psíquica.

Naquele momento, meu receio era não me sentir preparada para o exercício da escuta especial, da livre associação e das intervenções adequadas, pois não tinha as condições que julgava necessárias, que seriam a prática e o saber teórico suficientes. Precisava fazer com que o grupo se sentisse à vontade para falar abertamente, permanecer em estado de atenção flutuante e reconhecer os momentos apropriados para fazer intervenções que perturbassem aqueles professores.

Entretanto, em um curso de formação, precisava também criar estratégias para manter o grupo atento e interessado, evitando fugas em relação ao tema em discussão, preocupação pouco ressonante com a de uma escuta flutuante. Enfim, tinha a expectativa de realizar um trabalho como formadora e pesquisadora que resultasse num efeito impactante nos professores e que também fosse interessante sob o ponto de vista da minha pesquisa acadêmica.

Até então, a angústia dos momentos que precederam o meu encontro real com o grupo, poderia ser encarada como um sentimento natural e compreensivo, diante da minha inexperiência numa situação completamente nova. Esta seria uma explicação superficial e insatisfatória, quando o que se pretende é ir além de uma proposta de reflexão sobre a própria prática,baseada na especulação ao nível do ego. Mas meu objetivo é avançar mais no questionamento das posições subjetivas que considera as projeções dos níveis inconscientes - nas quais eu me encontrava, 
seja em meus momentos de reflexão mais íntimos, seja no momento das minhas ações.

Por isso, antes mesmo de entrar na análise da minha experiência propriamente dita - que incluem as ações e reflexões realizadas durante o evento - aproveito primeiro para mergulhar nessa prévia sensação de angústia, para tentar desvelar essas projeções do inconsciente. Porém, alerto para a complexidade da tarefa. Primeiro, porque pressupõe que um sujeito que pretende "conhecer a si", se disponha a um descortinamento de véus, a uma "exposição de vísceras", à dor de suportar o que lhe vier à vista. No meio disso, há o enfrentamento de uma recusa, de um não-querer-saber, mas que deve culminar na responsabilização pelo que se vier a saber.

\section{Explorando a sensação de angústia}

Não é difícil perceber, e, a seguir, concluir, que a sensação de angústia referida nos parágrafos anteriores tenha uma causa provável, que é o meu desejo de obter controle sobre toda a situação, incluindo a mim e ao grupo de professores. O horror que me causava a simples idéia da perda do controle se assemelha ao momento, segundo Lacan, em que a criança se dá conta de que não é tudo para a mãe, e por isso se pergunta "o que ela quer de mim?". Esforça-se para preencher todo o seu espaço, tenta ser seu único objeto de desejo, objeto de desejo do Outro.

A perda do controle está relacionada com a pergunta "o que Outro quer de mim?", o que os Outros, no meu caso, a comunidade de pesquisa, meu orientador, Malu, o grupo de professores, os formadores de professores, esperam de mim? Até a própria Psicanálise, cujo saber representa uma referência simbólica - já que também tecida pela cultura - chega a ocupar esse lugar de Outro. Ou seja, todos esses seriam Outros para quem, inconscientemente, eu estaria prestando contas e não querendo desapontar. Para Lacan, (Seminário 10, 1962-63,) a angústia "é o afeto sentido pelo sujeito, em uma vacilação, quando é confrontado com o desejo do Outro" ou ainda, "a angústia é sempre aquilo que nos deixa dependente do Outro, sem nenhuma palavra, fora da simbolização". (Lacan apud Chemama, 2002, p.14-15). 
Porém, Lacan nos mostra que o Outro também é barrado, isto é, que o Outro nem sempre está ciente (consciente) do que deseja (inconsciente). Ora, a saída que o sujeito deve encontrar para a alienação ao desejo do Outro é a sua separação, único modo dele deixar de ser objeto para ser sujeito desejante. Talvez, pior do que a angústia de tentar imaginar "O que o Outro quer de mim?", seja descobrir que para essa pergunta não há resposta.

No caso do professor, antes que ele se dê conta dessa impossibilidade, seu imaginário começa a funcionar a partir de algumas respostas prontas, assumidas como um saber a priori. A própria idéia de controle - particularmente o controle sobre os efeitos da educação nos sujeitos - já é uma dessas respostas que comumente vem objetivando o papel do professor e quem nos fornece uma resposta, por exemplo, é o Outro da Pedagogia. Um Outro que "ninguém conhece, ninguém viu, ninguém sabe onde mora (...) mas que é a ele que se deve obedecer", citando Lajonquière quando fala sobre educadores que agem em nome do "pedagógico". O problema é que esse Outro - que veicula um discurso que habita o imaginário do professor - "transforma sua existência num pesadelo sem fim", uma vez que professa uma ilusão no cotidiano escolar ao tentar "produzir crianças felizes e criativas sintonizadas com o futuro". (Lajonquière, 1999,p.27-31)

Para esse autor, a pedagogia e a psicologia - que pretendem uma adequação entre a intervenção do adulto e o estado psicomaturacional das crianças - crêem na possibilidade de se encontrar meios de ajustar a intervenção dos educadores a um suposto estado natural da capacidade dos estudantes. Ora, esses meios nada mais são do que procedimentos, métodos que os educadores devem adotar para obter sob seu controle, suas próprias atitudes e as dos educandos, bem como os resultados que tais ações devem atingir.

A Psicanálise nos ensina, por meio das palavras de Millot (1987,p.149), que "teoria pedagógica alguma permite calcular os efeitos dos métodos com que se opera, pois o que se interpõe entre a medida pedagógica e os resultados obtidos é o Inconsciente do pedagogo e o do educando". Isso quer dizer que tão fora de controle estão os efeitos dos métodos quanto estão os próprios educadores e seus educandos. Porém, isto não significa que os professores devam abandonar os 
alunos a própria sorte, por não saberem mais, por exemplo, como lidar com a recusa ou a indiferença dos estudantes diante das atividades escolares. Tal atitude revela descompromisso ao não querer assumir a responsabilidade do que concerne ao papel de educador. Esta é uma saída que, para Lajonquière, significa a demissão do adulto da posição de educador, semelhante àquela comentada pelo mesmo autor, sobre a mãe que não consegue dizer não às demandas do filho: "como acho que não adianta, eu acabo mesmo dando". Ora, em nome daquele Outro da (psico)pedagogia moderna, pais e professores, "cada vez que se endereçam a uma criança abrigam o medo de vir a "estragar", isto é, de agir contra a natureza" (ibid.,p.33-37).

Esse Outro, que fala aos pais e professores, e que "acredita na tese da individualidade psicológica como resultante do desenvolvimento ajustado de capacidades orgânicas do indivíduo que amadureceriam graças a uma estimulação correta conforme o tempo" (ibid:32), instala um ideal a ser realizado. Esse ideal em Psicanálise corresponde ao "ideal do eu, conjunto de traços simbólicos implicados pela linguagem, pela sociedade e pelas leis" (Nasio, 1995,p.61) e que, para Lacan, sustenta o narcisismo, provoca uma série de problemas no campo da educação, entre eles, o mal-estar profissional. Um mal-estar que pode paralisar qualquer ação do professor, ou seja, demiti-lo de sua posição de educador.

Como um fantasma, o Outro persegue o professor, que passa a buscar desesperadamente os tais procedimentos de controle para a situação, que se parecem mais com mecanismos de auto-defesa. Na busca desse controle, muitas vezes antecipamos nosso encontro com o real, imaginando previamente como se dará nosso contato com o outro. Nisso, há pelo menos dois problemas: primeiro, acreditar que sabemos, de antemão, quem o outro é; segundo, qual deverá ser a sua reação frente a nós. Lacan (1954-5) nos diz que "antes da palavra, nada é, nem não é. (...). Não há verdadeiro nem falso antes da palavra" (1985, p.158), isto é, ele nos ensina que não há verdade nem mentira naquilo que tecemos previamente a respeito do outro, nem sobre nós mesmos. 


\section{Minha experiência propriamente dita}

Meu planejamento para o encontro com os professores, previu um trabalho em duas etapas:

I) na primeira, os professores responderam individualmente, durante o encontro e por escrito a duas questões elaboradas com a intenção de levantar as concepções a respeito do papel e do modo de lidar com a linguagem na sala de aula de ciências: "Qual o papel da linguagem nas aulas de ciências?" e "A linguagem é uma preocupação para você durante suas aulas? Em quais momentos?". Posteriormente ao questionário, foi sugerida a leitura do artigo "Concepções sobre o papel da linguagem no processo de elaboração conceitual em Química" de Machado \& Moura (1995) publicado na revista Química Nova na Escola. As respostas analisadas geraram uma síntese que foi apresentada aos professores no encontro seguinte.

II) na segunda etapa, os docentes fizeram, oralmente, comentários sobre a síntese apresentada e sobre o texto lido. Esse encontro foi gravado em áudio.

A aplicação de um questionário foi a forma que escolhi, inicialmente, de conhecer as concepções dos professores a respeito do assunto. Contudo, na aplicação de um questionário com perguntas diretas e objetivas, as chances dos professores se colocarem subjetivamente é pequena. Ora, se a minha intenção era, de fato, trabalhar elementos da fala dos professores em livre associação, de praticar a escuta especial, a atenção flutuante e o exercício das intervenções, como justificar a escolha de uma estratégia que não me permitiria atingir tais objetivos? Por que não escolhi uma estratégia mais adequada para este fim - e também para a coleta dos dados - por exemplo, abrindo as questões para o grupo sob a forma de um debate?

Poderia, a princípio, admitir como verdade, que me faltavam as condições que julgava necessárias, que seriam a prática e o saber teórico suficientes. De fato, concordamos com os autores (Carvalho \& Gil Perez, 2001; Tobin \& Espinet, 1989; Ostermann \& Moreira, 2000; Terazzan et al., 2000), cujas pesquisas têm apontado que uma das dificuldades dos professores em adotarem atividades inovadoras em 
suas práticas esteja ligada à falta de domínio dos saberes conceituais e metodológicos de sua área.

Ainda a respeito das mudanças desejáveis nas práticas docentes e de um problema mais específico do ensino das Ciências, encontramos em outros pesquisadores (Gunstone \& Northfield, 1992; Duschl \& Gitomer, 1991; Gil Perez \& Castro, 1996) um consenso geral, por exemplo, sobre a necessidade de se investir na alteração das atuais concepções de professores a respeito do uso de atividades práticas de laboratório. Esses autores consideram que tais alterações exigiriam do professor, além de uma mudança de visão sobre a atividade científica, uma mudança de posição em face do processo ensino/aprendizagem, na qual o professor coloca-se como mediador, procurando incentivar e orientar o aluno na busca das respostas.

Mas, para além do domínio dos saberes práticos e teóricos necessários e da investigação sobre as concepções dos professores a respeito da Ciência e de seus métodos, as pesquisas na área de formação de professores poderiam nos revelar dados ainda mais interessantes se, de fato, resolvessem incluir o papel do inconsciente no processo educativo. Estamos falando sobre entender o que se passa subjetivamente com os professores diante de uma mudança de posição que é o resultado desejado a partir de todo esse investimento. Isto significa especular sobre as posições subjetivas dos sujeitos, às voltas com suas práticas, o que implica e numa mudança na natureza dos questionamentos, das reflexões habituais dos professores.

Quando me questiono, por exemplo, sobre como justificar a escolha de uma estratégia que não me permite atingir os objetivos traçados ou porque não houve a escolha de uma estratégia mais adequada, estou procurando os motivos inconscientes que me levaram a realizar uma coisa, quando se desejava outra. Isto significa que estamos considerando que as escolhas que fazemos, muitas vezes, são respostas inconscientes, estruturadas a partir de uma lógica própria ao inconsciente. E esta lógica pode ser revelada, acreditamos, a partir da especulação das minhas posições subjetivas em relação ao outro, ao Outro, ao desejo. Em outras palavras, a partir de qual referência fazemos nossas escolhas, tomamos 
nossas decisões como educadores? Pois - repetindo Mrech na abertura deste capítulo - "a transmissão do saber não é isenta. Nós sempre nos posicionamos de alguma forma frente a ele, mesmo que seja a partir da posição de objeto".

No cotidiano escolar, muitas das escolhas que fazemos nunca passaram por questionamento algum. São situações que durante muito tempo vêm se repetindo e cuja função, para Mrech, seria defender os sujeitos de sua própria ignorância: "Eu não posso revelar ao outro o que não sei. Eu não posso dizer que eu não sei. É melhor eu nem pensar nisso!!!” (Mrech, 1999, p.91). Na eminência de revelar suas falhas ou dificuldades diante de uma situação desafiadora, os sujeitos são capazes de apresentar múltiplas razões conscientes para tentarem se isentar de qualquer responsabilidade sobre suas escolhas. Essa postura merece um questionamento mais profundo que permita aos sujeitos fazerem contato com aquilo "que eles não percebem que não desejam saber, que querem continuar a ignorar". Como exemplo, vamos abrir parênteses para discutir o comentário de uma das professoras do grupo, sobre o seu trabalho com o debate como recurso didático em sala de aula, tarefa obrigatória sobre a qual os professores se debruçaram durante quase todo $01^{\circ}$. semestre do curso de formação.

A princípio eu achei que não ia dar certo. Eles [os alunos] não estão acostumados com atividades diferentes. Eu estava quase desistindo.Eu mesma levei um material prevendo que nem todos eles iriam trazer [o material exigido para a atividade].Eu precisava dar serviço para todo mundo da sala. Eu propus que eles se dividissem, assumindo papéis diferentes. Aí eu falei pra eles: "Vou fazer o debate e isso vai ter que valer nota". Mesmo sabendo que valia nota, eles não estavam tão preocupados. Eles estão acostumados com debate na aula de história, geografia, mas não na aula de química! Mas para minha surpresa, foi justamente na hora que de fato o debate aconteceu. [grifo meu]

A professora parecia mais preocupada e apreensiva do que os alunos diante de uma atividade que ela julgava "diferente" apenas para eles. Nesse caso, a professora projeta no outro (no caso os alunos) a sua própria dificuldade com uma prática diferenciada, visto que ela mesma afirma que "eles estão acostumados com debate" em outras aulas. Parece claro que a experiência era nova para a professora, de modo que ela se mostrou ansiosa por procurar meios para garantir 
um certo controle sobre a situação, por exemplo, determinando que "isso vai ter que valer nota". Tentou também prever as ações dos alunos, levando material extra, se preocupando em "dar serviço para todo mundo da sala" e designando papéis para os grupos. A relação entre fazer a atividade "dar certo" e deter o controle sobre as variáveis envolvidas, merece ser questionada, no caso da professora, e que não pode ser tratada apenas como uma preocupação racional que envolve 0 planejamento de uma aula.

Para além do pensamento racional, estão presentes nos sujeitos fatores de ordem inconsciente que os amarram em determinadas posições. Acreditar que se pode ter o controle de uma situação e de seus efeitos, como no caso da ação pedagógica, é um exemplo de uma posição que tem sido fortemente combatida pelos autores que pensam a educação a partir do referencial teórico da psicanálise. A tese central é que "não há outro domínio possível senão o do Eu, aquele que se exerce conscientemente, mas trata-se de um domínio ilusório, pois é o Inconsciente (aquele que sai pela boca quando menos se espera) que demonstra possuir um peso muito maior que todas as intenções conscientes" (Lopes, 2005, p.84).

O caso desta professora mostra o quanto ela estava, a princípio, insatisfeita com a mudança de posição que lhe obrigava a abrir mão do controle que acreditava ser necessário para que a aprendizagem dos alunos ocorresse. No entanto, ao aceitar o desafio da novidade, sua experiência pôde lhe mostrar o equívoco dessa crença, e a mudança de satisfação diante do resultado positivo obtido com a turma, ela própria confirmou no final quando declarou "para minha surpresa...o debate aconteceu".

O que se esclarece nos dois casos, salvo a tentativa da professora em transferir para o outro uma responsabilidade pessoal, é que a perda do controle mediante uma mudança de posição, se traduz como medo inconsciente de não se conseguir sustentar uma posição na qual se pode ser surpreendida. Para a professora, esse medo quase impediu que ela ousasse uma prática não habitual. No meu caso, implicou numa escolha na direção contrária ao meu desejo. 


\section{O resultado do primeiro encontro: interpretando o questionário}

Apesar do uso do questionário com perguntas diretas como estratégia para obtenção de dados de teor subjetivo inibir, de um lado, declarações espontâneas dos professores, e do outro, o exercício da escuta especial e das intervenções adequadas por parte da pesquisadora, considerei viável, por meio da leitura atenta das respostas, a captura de qualquer pista que pudesse significar a presença de concepções arraigadas, estereótipos e situações repetitivas nas práticas dos professores. Qualquer sinal de fuga da dimensão cognitiva a respeito do uso da linguagem na sala de aula, naquele momento serviria como material para um posterior aprofundamento das reflexões junto ao grupo.

É importante deixar claro que, na busca pelas concepções dos professores sobre o papel da linguagem, não houve pretensão de se fazer uma análise das definições empregadas para termo linguagem - embora este risco esteja presente muito menos àquelas que o termo recebe no campo da Lingüística, mas sim daquilo que a expressão do pensamento dos sujeitos, na escrita, pode depreender da prática docente. Vejamos, pois, qual o rumo tomado pelas respostas dos professores ao questionário.

A princípio, ao analisar as respostas dos oito professores (Ana, Geisa, Tina, Cintia, Davi, Bete, Magda, e Zilda) que entregaram o questionário, percebi semelhanças em relação aos dados apresentados no artigo de Machado \& Moura, em pesquisa com profissionais do ensino de ciências ligados à UFMG. Assim como no artigo, a idéia básica encontrada na maioria das respostas, mostra a linguagem como meio para comunicar, expressar, informar, transmitir, adquirir e entender uma mensagem, como vemos a seguir:

Cintia: A linguagem é a nossa maneira de comunicação, de expressar nossas idéias e principalmente de nos fazer entender. Se conseguirmos expressar as nossas idéias, passamos as informações necessárias.

Geisa: A linguagem exerce papel fundamental, pois é através dela que conceitos e conhecimentos são transmitidos e adquiridos. [grifo meu]

Essa mensagem é compreendida como idéia, conhecimento, informação, conceito, aprendizado a serem passados do professor para o aluno. Segundo 
Machado e Moura, esta forma de conceber a linguagem incorpora a concepção de linguagem como instrumento, caracterizado como "via de mão única", onde a palavra do professor é reforçada como "fonte de conhecimento" e o aluno é o "receptáculo".

Um outro aspecto interessante das respostas é aquele no qual os professores apontam a linguagem como sinônimo de vocabulário. A escolha do vocabulário parece permitir fazer um ajuste da expressão ao que se considera mais adequado aos alunos.

Bete: Tenho a preocupação de expressar-me usando termos técnicos adequados e corretos. Acho fundamental desenvolver a linguagem própria da química, porém, também deve se usar a linguagem usual como elo entre dois pólos: científico e cotidiano. Os termos técnicos devem ser "traduzidos" ou exemplificados com vocábulos do contexto do aluno. [grifo meu]

Essa visão implica num conflito que se percebe unânime para o grupo de professores: o uso da linguagem científica, dos termos técnicos, específicos da ciência versus o uso da linguagem cotidiana, usual, coloquial. Até aqui, essa é uma discussão comum - como já dissemos anteriormente - entre os professores e pesquisadores da área e reflete uma preocupação com o uso da linguagem e a elaboração de conceitos pelos estudantes. De uma leitura em primeiro plano das respostas dos professores, foi possível extrair que o papel da linguagem permanece em sua dimensão cognitiva, com a função de mediação entre aluno e o conhecimento. Isto não significa que tal dimensão mereça ser desprezada, ao contrário, ela será o ponto de partida para dar prosseguimento à discussão junto ao grupo.

Mas também pode-se dizer que as respostas padronizadas ao questionário, refletem uma posição subjetiva do grupo de quem se refere ao Outro - no caso, a formadora - tentando obter a resposta à pergunta "o que o Outro quer de mim?". Desse modo, justifica-se, mais uma vez, a minha necessidade de adotar uma estratégia complementar, que seria a fala livre dos docentes num segundo momento, para poder extrair deles informações para além de suas representações conscientes. 
Porém, uma segunda leitura das respostas trouxe dados mais interessantes, mais próximos do objetivo que eu pretendia atingir. Eles me permitiram perceber outros aspectos do papel da linguagem. Aspectos que estariam ligados aos efeitos subjetivos que seu uso provoca nos sujeitos. É o caso das professoras que escreveram:

Geisa: Uma linguagem muito longe do vocabulário e da realidade dos alunos causa desinteresse por parte dos mesmos.(...) Uma linguagem diferente da coloquial valoriza o trabalho do professor, facilitando o respeito mútuo.

Cintia: É o momento onde temos que respeitar o falar e também o ouvir. [grifo meu]

Nessas falas destacamos uma nova dimensão para a linguagem, ampliando pois, o seu papel. Ela facilitaria ou inibiria o interesse dos alunos em relação ao aprendizado, valorizaria a posição do professor enquanto autoridade em relação ao conhecimento, mediando a atitude de respeito entre os indivíduos. A impressão que temos é que a linguagem é usada para além da intenção instrumental, no sentido em que foi apontado anteriormente, mas cumpre uma função relacional, que permite aproximar ou afastar, não apenas os alunos do conhecimento, mas os alunos e os professores.

Embora as funções instrumental e relacional da linguagem tivessem surgido entre as respostas, isso não significava que tais noções estivessem claras para os professores. No entanto, minha intenção é que elas se tornassem explícitas no momento em que eu as devolvesse na forma de síntese para o grupo.

\section{Enfrentando o segundo encontro: o momento da fala livre dos professores}

A síntese das idéias do grupo gerou um painel que foi elaborado previamente com a intenção de facilitar, para os professores, a compreensão dos pontos em destaque. Mas, quando um professor se preocupa em "facilitar a vida" dos seus aprendizes, em nome de alguma garantia de aprendizagem, tal pensamento merece uma reflexão.

Arruda et al., em seu artigo "Da aprendizagem significativa à aprendizagem satisfatória na educação em ciências" (2004), trabalham com a noção de satisfação 
inconsciente ao analisar o caso de uma professora cuja prática docente, segundo ela, tornava a Física facilmente inteligível para todos os alunos. Quando questionada sobre como ela lidava com os conflitos cognitivos de seus alunos, ela responde: "Eles não têm conflitos. Eu não deixo...Não suporto ver o aluno sofrer". Não era somente para aumentar a aprendizagem de seus alunos que a professora operava com sua didática, mas para alimentar sua satisfação inconsciente, que consistia em evitar que os alunos sofressem caso experimentassem conflitos cognitivos. Para ela, segundo os autores, sofrimento e aprendizagem eram significantes em oposição, que orientavam sistematicamente (e inconscientemente) seu trabalho em sala de aula.

Antecipar ou evitar o trabalho de elaboração intelectual dos alunos diante dos desafios escolares, não somente revela a posição subjetiva do professor da qual ele extrai uma satisfação inconsciente, como vimos, mas também serve para expiar um sentimento de culpa. A culpa, para Freud, é um sentimento inconsciente que é causa, que é anterior ao ato. $\mathrm{O}$ eu acredita ser culpado pois enfrenta o conflito entre a não realização do seu desejo, que equivaleria à proibição do gozo, e o pressentimento de chegar perto demais de consumá-lo, de experimentar o gozo pleno. A culpa é uma forma elaborada da angústia de castração. $O$ sujeito está entre a proibição e o ardor de seu desejo. Para ser tolerada, a angústia (culpa) necessita de autopunição, uma ação que desfaça essa tensão (Nasio, 1989,p.136138). Ora, se o desejo do professor é transferir todo seu conhecimento para os seus alunos e isto significa a realização do gozo pleno de produzir outros iguais a si mesmo - o que para a psicanálise é impossível de se atingir (embora se possa experimentar um gozo parcial) -, visto que o professor é castrado, a autopunição para ele seria infligir-se um sofrimento, que pode ser sofrer no lugar do aluno.

A organização de um quadro sintético que apresentava para os professores as conclusões prévias a respeito de suas concepções, antecipou uma parte do trabalho intelectual do grupo e serviu para evitar o sofrimento dos professores diante da tarefa. Também me serviu de apoio em vários momentos durante a atividade, já que possibilitou orientar a discussão, evitando a fuga dos professores 
em relação ao tema. Obviamente que isso também tem a ver, mais uma vez, com minha tentativa de controlar a situação.

A idéia de retornar as respostas aos professores teve inspiração no trabalho de Silva \& Schnetzler (2000), baseado no uso de textos que apresentam situações homólogas vividas por outros professores que funcionariam como "espelhos", nos quais os docentes em formação veriam refletidas as suas práticas pedagógicas. $O$ uso de situações educacionais simuladas é uma estratégia formativa proposta por Schön, designada "sala de espelhos", cujo objetivo é possibilitar aos professores avaliarem e reformularem suas próprias práticas. No nosso caso, as situações homólogas foram substituídas pelas idéias dos próprios professores, de modo que o espelho, projetando a própria imagem do grupo, os dirigisse a uma auto-reflexão e evitasse o risco de caírem no julgamento de ações alheias.

O trabalho de Silva \& Schnetzler mostra claramente a resistência inicial de um grupo de professores em formação continuada, em relação a um programa que propõe a reflexão, no lugar do ensinamento de técnicas e receitas prontas para serem aplicadas em sala de aula. Para atender à demanda dos professores, as formadoras resolvem incluir atividades experimentais relativas ao ensino de conteúdos específicos e, ao mesmo tempo, escolhem textos que relatam ou simulam exemplos de práticas pedagógicas desenvolvidas por outros professores, para estimulá-los à reflexão. As formadoras chamaram essa tática de "caminho do meio", pois permitiu estarem com "o pé na realidade dos professores" e, ao mesmo tempo, atingir o objetivo inicialmente traçado por elas, que era promover a reflexão docente. A atitude das formadoras serve, em primeiro lugar, de alerta para aqueles que conduzem cursos de formação que carregam a bandeira do professor reflexivo, correndo o risco de executarem uma prática esvaziada de sentido. Em segundo lugar, mostra que as formadoras souberam abrir mão (parcialmente) de seu desejo, caso contrário, condenariam seu curso ao fracasso. Contudo, em vista de nossa proposta, valeria a pena um questionamento mais profundo das concepções das formadoras sobre prática reflexiva, pois, encontramos no mesmo trabalho, a fala de uma delas deixando escapar uma comparação entre o ato reflexivo e o "luxo de divagar". 
Chegado o momento do segundo encontro, apareceu também uma nova angústia. A fala livre dos professores implicaria em me suportar numa posição na qual poderia ser surpreendida a qualquer momento. Isto significaria o risco iminente de me ver subtraída da minha posição de "Mestre Todo-Saber", aquele mestre ideal, sabedor de tudo. Isto é, significaria enfrentar a dor de suportar a minha própria condição radical de incompletude.

Mas para quem eu presumia (inconscientemente) que devesse prestar contas da minha condição? Para os professores e, principalmente, para Malu, que decidiu participar do segundo encontro. Uma imagem idealizada de Malu foi sendo construída à medida em que observava suas ações com os professores, as quais demonstravam segurança e firmeza, ao mesmo tempo, leveza e descontração. Havia um sentimento de que eu não poderia decepcioná-la, como se houvesse a obrigação de "pagar uma dívida" na mesma moeda, para quem estava se dispondo a me oferecer a condução da aula. Dessa forma, Malu se torna para mim o Outro, para quem "o sujeito 'castrado' está sempre se apresentando, procurando atrair a atenção e o reconhecimento e, quanto mais se apresenta, mais inevitavelmente castrado se torna" (Fink, 1998, p.97).

\section{A linguagem revelando novos conflitos}

Embora tivesse planejado iniciar a discussão a partir da apresentação do quadro sintético, comecei dando a palavra a dois professores que não estavam presentes no primeiro encontro e que não haviam respondido ao questionário, Ilda e Jonas. Mas, persistindo na idéia original de colocá-los em posição de livre associação e manter-me em atenção flutuante, preferi aguardar uma oportunidade de introduzir a minha síntese a partir das falas dos professores e daí, fazer o mínimo de intervenções que me fosse possível.

\section{I- Negando a posição do Mestre}

As falas que selecionamos para análise são o resultado de recortes, nos quais se percebe os professores deslizando de suas concepções iniciais sobre o uso da linguagem - destaque para a sua função cognitiva e mediadora - para uma 
dimensão mais subjetiva, que marcam os sujeitos em determinadas posições, as quais temos interesse em desvelar.

Comecemos pela colocação de Jonas (professor de biologia), quando abordado pelas perguntas do questionário:

Eu acho complicada essa questão da linguagem hoje em dia, porque a gente vê que hoje em dia, por mais que a gente estude, por mais que a gente tenha um bom nível cultural, cada vez mais a gente está se distanciando do nosso aluno. (...) Porque cada um tem o seu código de linguagem. Cada um tem o seu e com certeza a gente jamais vai conseguir entender o que eles estão falando e vice-versa. (...) Quanto mais termos difíceis a gente usa, menos a gente consegue se aproximar do aluno.(...) Eu tenho essa linguagem, eu tenho esse poder, só eu posso usar e ponto final.[grifo meu]

$\mathrm{Na}$ fala do professor Jonas, o uso de linguagens diferenciadas por parte de professores e alunos causaria um conflito, um ruído na comunicação entre eles, de modo a dificultar a aproximação entre eles, ainda que no nível da cognição, no processo de ensino-aprendizagem.

Para além do conflito mais óbvio posto anteriormente a respeito do uso da linguagem científica versus o uso da linguagem cotidiana na sala de aula, está o aparente sentimento de "quase culpa" que se apodera do professor e que parece não permitir que ele se sustente na posição de mestre, daquele que detém um saber a mais que o diferencia e o eleva em relação aos seus aprendizes. A fala de Jonas demonstra o desconforto que lhe traz estar na posição de professor pelo fato de que professor "é gente que estuda, gente que tem um bom nível cultural", e que por isso, "cada vez mais está se distanciando do nosso aluno".

O que convém ser questionado aqui é como o professor conduz sua posição de mestre, o que ele faz com "essa linguagem, esse poder", que ele mesmo afirma ser inerente à sua condição. No caso dos professores de ciências, seu papel é o de promover a entrada dos aprendizes na linguagem - que é confundida por Jonas com o uso de termos difíceis - e no pensamento científico. Para Machado (2000), a linguagem científica é mais do que uma forma de registrar ou descrever um fenômeno, mas é um instrumento que ajuda na elaboração de uma certa forma de pensar, de se construir uma certa lógica, que é própria da ciência. 
Então não adianta nada a gente querer dar uma aula de química, de ciências ou biologia se eu fico dando uma de professor erudito, complicado, porque meu aluno não vai entender nada daquilo que eu estou explicando. Com certeza na hora que ele for escrever na prova, com a linguagem dele, eu vou colocar errado, porque não foi aquilo que eu falei.(...) Então quando o aluno usa uma gíria numa prova, nós temos o péssimo hábito de estar reprovando esse aluno. Isso é muito sério, eu acho que a base do nosso trabalho tem que ser essa linguagem.[grifo meu]

Do nosso grifo, depreende-se que os professores, na visão de Jonas, estariam desconsiderando o modo peculiar de expressão dos nossos alunos e com isso contribuindo para o seu fracasso, para sua exclusão da cultura escolar. Tal postura nos parece não ter a ver com inclusão ou exclusão, aprovação ou reprovação, mas principalmente, com a negação do lugar do mestre, aquele que comporta um saber que o aluno não tem, o lugar de onde o professor deve, primordialmente, falar. Portanto, acreditar que se deva aceitar, no contexto da aprendizagem específica das ciências, o modo (im)próprio de expressão oral ou escrita do aluno - além de atestar uma confusão conceitual entre linguagem, código e vocabulário - comporta uma falsa idéia de inclusão e que pode levar o professor a um ato de subversão do seu papel.

No momento da fala de Jonas, recordei-me do estudo de Charlot (2000), que aborda a relação entre fracasso escolar e linguagem, notadamente dos alunos dos bairros populares de Paris, cujo texto "Práticas Linguageiras e Fracasso Escolar" fora discutido em encontros anteriores do grupo:

Pesquisadora:Você falou uma coisa que está nesse texto. Ele [Charlot] está falando justamente sobre isso: as práticas de linguagem nos diversos grupos. Ele vai focalizar as classes populares e vai falar da linguagem usada por esses grupos e do fracasso escolar, então entra bem nisso que você estava falando. [grifo meu]

Embora eu tenha percebido na fala do professor Jonas a demonstração de uma conduta subversiva em relação ao papel do professor de ciências, acabei endossando sua posição ao fazer referência a Charlot, quando na verdade, o seu texto aponta na direção contrária. Charlot nos diz que a escola "tem de estar atenta a que as práticas de expressão e comunicação dos jovens de bairros populares não 
sejam desvalorizadas. Mas a escola é também um lugar de aprendizagem, formação, reflexão, um lugar cognitivo ligado à cultura escrita"(ibid.,p.132).

O fato interessante é que, naquele momento, eu também estava subvertendo o meu papel de formadora. Ao invés de aproveitar a oportunidade de intervir, chamando a atenção do grupo para os conceitos confusos e equivocados do meu professor-aluno, estava evitando, sem me dar conta, cometer um ato de reprovação e exclusão desse professor.

$\mathrm{Na}$ seqüência, a linguagem do aluno, como reflexo do mundo a sua volta, é utilizada por Jonas para fazer uma aproximação com o conteúdo ensinado:

Na minha experiência, a gente fala muito em cadeia trófica. Mas o que é isso? "Cadeia" eles sabiam porque faz parte da realidade deles... [risos] (Jonas faz ironia por causa dos alunos da professora Zilda que são da Febem). (...) Aí eu falo: "gente, o produtor e o consumidor, a presa e o predador..”. Tá bom, um come o outro. Aí, cai no linguajar deles, então aí ele vê quem vai ser comido e quem come o outro. (...) Se você ensinou que a cadeia trófica é uma relação de presa e predador $\boldsymbol{e}$ se você contextualiza essa experiência, aí o aluno entende. Ali na hora de fazer o exercício ou uma provinha, aí ele consegue entender o que você está pedindo.[grifo meu]

Contextualizar um episódio de ensino como estratégia, para aproximar o conteúdo escolar da chamada "realidade do aluno", é uma prática docente que encontra respaldo teórico nos documentos oficiais que legislam sobre a Educação, como é o caso dos Parâmetros Curriculares Nacionais. De acordo com os PCNEM (1988), "é possível generalizar a contextualização como recurso para tornar a aprendizagem significativa ao associá-la com experiências da vida cotidiana ou com os conhecimentos adquiridos espontaneamente". Mas o texto alerta, logo a seguir, que é preciso cuidar para que essa prática "não induza à banalização, com o risco de perder o essencial da aprendizagem escolar que é seu caráter sistemático, consciente e deliberado"(1988,p.82).

Porém, interpretamos que o risco apontado pelos PCNEM, quando se trata de apreender a "realidade do aluno", atinja uma dimensão para a qual existe a necessidade de uma reflexão que não encontramos nos mesmos textos. Essa 
dimensão é ainda maior para Charlot e de uma outra ordem para a psicanálise, nos quais encontramos subsídios para discutir nosso ponto de vista.

Charlot, em seu texto supracitado, aponta que a desvalorização da linguagem popular do aluno gera efeitos negativos tais como a inibição do falar e a violência simbólica como oposição à própria escola, pois "o que assim está desvalorizado é a sua própria identidade e seu grupo, sua cultura, seu conjunto de costumes sociais e valores"(ibid.,p.129). No entanto, a escola deve trabalhar essa relação com a linguagem de modo a permitir a construção de novos universos intelectuais ao fazer "entender que falar e escrever é também ser, (...) trata-se igualmente de mudar o mundo e mudar-se, notadamente de diminuir as desigualdades sociais"(ibid.,p..133). Ao permanecer no universo do aluno, cair no linguajar deles, como Jonas nos coloca, corre-se o risco de perpetuar uma condição sócio-cultural e ao mesmo tempo, impedir que se atinja novos graus de liberdade com os quais é possível entender melhor o mundo, a vida e a si mesmos.

O contexto a que Charlot se refere está mais próximo do conceito de realidade social na psicanálise freudiana, que difere do conceito de realidade psíquica. Embora ambas passem a ter existência a partir da linguagem, como resultado da simbolização, elas não podem ser tomadas como a mesma coisa. Alunos de uma mesma escola podem se encontrar inseridos numa mesma realidade social, material ou concreta, como é o caso dos alunos dos bairros populares de Charlot, dos alunos do professor Jonas e dos alunos da Febem, da professora Zilda. Entretanto, a realidade psíquica, que é a realidade tal qual ela é tecida e estruturada na mente do sujeito, a partir de seu modo único e singular de conceber o mundo, os outros e a si mesmo, difere, portanto, entre os sujeitos. O acesso à realidade psíquica do aluno estaria portanto interditado ao professor que julga poder capturálo a partir da realidade social, já que são tomados como sendo a mesma coisa.

Assim, para a psicanálise, constituir-se-á um empreendimento fantasioso para o professor apostar na significatividade do ensino "partindo da realidade do aluno", ou "conhecendo a realidade do aluno". Visto que uma parcela dessa realidade é da ordem do inconsciente, desvendá-la não é uma tarefa simples; não é da competência do professor, muito menos é objetivo da educação escolar. Isso levado 
em conta, supor que entre as essências da aprendizagem escolar está o seu caráter consciente e deliberado é desconsiderar a interferência do inconsciente e do saber que ele veicula e se faz presente nesse contexto.

Embora não me fosse possível realizar uma intervenção eficaz de alertar o grupo para essas questões, interpretei o episódio relatado por Jonas - que para muitos autores nada tem a ver com contextualização - apenas como uma tentativa de atrair a atenção do aluno a partir do enganchamento do conteúdo com sua realidade social. O importante era resgatar a posição do mestre, isto é, reforçar o papel do professor na sala de aula de ciências:

Acho que num primeiro momento, essa aproximação da linguagem do aluno é mais para você sensibilizar, chamar a atenção, capturar esse aluno. Depois que você capturou, você pode desenvolver o seu papel. $\mathbf{N a}$ verdade a gente está lá para trabalhar a linguagem científica..[grifo meu]

Como afirma Charlot, "as palavras são cheias de sentidos e valores que correspondem às pertenças sociais e culturais e às identidades coletivas" (ibid.,p.129). A tentativa de Jonas em aceitar os modos de expressão (im)próprios do aluno, pode ser interpretada não apenas como uma maneira de aproximar o aluno da escola, da cultura escolar, do conteúdo a ser ensinado, na pretensa (e talvez equivocada) intenção de minimizar o fracasso do jovem. Existe também uma tentativa de alguns professores em aproximarem sua própria linguagem à do aluno, lançando-se numa posição que exprime sua relação identificatória com ele.

O traço que marca o aluno de Jonas enquanto grupo, enquanto identidade coletiva é a linguagem, "o linguajar dele, a gíria, o código". Na medida em que o professor se identifica com esse traço, com esse aspecto do outro, eliminam-se as diferenças. Diferenças que Jonas tem dificuldade em sustentar e as quais ele deveria trazer como sua marca enquanto professor e mestre, enquanto "gente que estuda, gente que tem um bom nível cultural". Segundo Miranda (1998), "se o sujeito estaciona neste nível de identificação com o outro, a culpa ora ou outra se instaura. (...) para existir troca é necessário que existam diferenças. Mas, em uma 
relação, quando duas pessoas tornam-se ilusoriamente uma só, a relação deixa de existir “(1998.,p.79).

Um outro exemplo disso se mostra na atitude do professor que se alia aos alunos em suas lamentações e queixas. No nosso caso, basta observar o diálogo entre as professoras Geisa e Magda sobre as dificuldades dos seus alunos em compreenderem instruções básicas, segundo elas, dadas em sala de aula:

\footnotetext{
Magda: Você escreve na lousa: "abra a apostila na página 7", tá escrito na lousa e você falou. Parece que não "entra" sabe, coisas assim... as mais simples... eu não sei o que está acontecendo.

Geisa: Hoje eu tive uma experiência cruel no laboratório. (...) Tinha lá uma reação de síntese que eu falei: "gente vocês vão colocar a substância nos dois algodões, tal e tal... depois que vocês fizerem isso, observem o que formou, joguem fora os algodões e liguem o bico de Bunsen". O que a criatura me fez? Pegou o algodão, pôs na pinça e foi queimar no bico de Bunsen. Eu falei: "Gustavo, foi isso que eu falei?" [aluno]: "a senhora não falou para pegar o algodão e acender o bico de Bunsen? Não era para queimar?”. Então, é passo a passo. Agora eu tô fazendo uma por uma, entre cada uma eu paro, vou na lousa.

Pesquisadora: Quando eu dou aula de laboratório eu também dou o roteiro, tudo por escrito. Mas dá trabalho, tenho sempre que ler com eles...[grifo nosso]

Geisa: No procedimento está escrito lá: “ pegue o algodão, as bolinhas..." Já está tudo escrito lá, eles têm uma apostila de laboratório e eu ainda explico passo a passo.

Pesquisadora:Eu sei, eu também fico irritadíssima. Eu também tenho que fazer a mesma coisa.[grifo nosso]

Magda: Você dá experiência e o procedimento sempre tudo escrito e eles não lêem. Parece que não está entrando no ouvido. Eles não prestam atenção. [grifo meu]
}

A discussão, que aqui foi resumida, mostra em grifo a posição que assumi ao me juntar às lamentações das colegas professoras. Naquele momento, eu bem sabia da situação que elas apresentavam, pois, como professora, vivencio o mesmo impasse. E da mesma forma que elas, talvez também estivesse procurando uma resposta, uma saída para um conflito pessoal preexistente. E a obliteração de uma falta de resposta para as professoras encontrou uma saída, que foi alienar-me, deprimir-me, gozar com elas num extenso circuito de blá-blá-blá. 
O mal-estar das professoras encontrou ressonância junto ao meu, e no lugar de assumir o papel de ajudá-las a encontrar suas próprias soluções, ou seja, assumir o papel de mestre, nenhuma troca, nenhum novo saber a respeito do conflito que se expunha ali foi produzido então.

\section{II- Substituindo o mestre}

A relação identificatória tem sua origem, segundo Freud (1925-26), num vínculo afetivo com um objeto amado, desejado e perdido. Os primeiros objetos com esse caráter dos quais nos fala Freud em seu texto "Identificação", são o pai e a mãe. "Um menino mostrará interesse especial pelo pai; gostaria de crescer como ele, ser como ele e tomar seu lugar em tudo. Podemos simplesmente dizer que toma o pai como seu ideal. (...) Ao mesmo tempo que essa identificação com o pai, ou pouco depois, o menino começa a desenvolver uma catexia de objeto verdadeira em relação à mãe.(...) Apresenta então, portanto, dois laços psicologicamente distintos: uma catexia de objeto sexual e direta para com a mãe e uma identificação com o pai que o toma como modelo. Ambos subsistem lado a lado durante certo tempo, sem qualquer influência ou interferência mútua. Em conseqüência do avanço irresistível no sentido de uma unificação da vida mental, eles acabam por reunir-se e o complexo de Édipo normal origina-se de sua confluência. O menino nota que o pai se coloca em seu caminho, em relação à mãe. Sua identificação com eles assume então um colorido hostil e se identifica com o desejo de substituí-lo também em relação à mãe. A identificação, na verdade, é ambivalente desde o início; pode tornar-se expressão de ternura com tanta facilidade quanto um desejo do afastamento de alguém" (volXVIII).

Depois que a criança descobre que o pai já não corresponde à imagem primitivamente idealizada - pois interdita seu acesso à mãe - e que a mãe já não o tem mais como seu único objeto de desejo - pois revela também interesses fora dela, e um deles pode ser o pai - a criança fica com um sentimento de uma perda dupla. A criança é "expulsa do paraíso" e esses objetos amados e desejados estão perdidos para sempre. Sua busca incessante e inconsciente será, de agora em diante, recuperar esses objetos, voltar a ocupar o paraíso. Vejamos o que isso tem a ver com a declaração de Jonas: 
Hoje em dia tem a inversão de valores. É muito mais fácil você aprender na frente do computador, de um vídeo-game, de uma televisão, de um cinema, do que com um professor lá na frente falando com giz e lousa. [grifo meu]

Parece-nos que a fala do professor denuncia um sentimento de perda, semelhante ao da criança que foi expulsa do paraíso. Como a criança que sente que a mãe o substituiu pelo pai (tomado pela criança como modelo, e agora hostilizado por ela), o professor sente que o aluno colocou o computador, o vídeogame, a televisão e o cinema em seu lugar. Eis então o que o professor tem como objeto perdido: seu lugar na vida do aluno. A criança esforça-se para preencher o espaço total de desejo da mãe, formando com ela quase que uma unidade mãecriança, até que o pai entre como um terceiro nessa relação. De uma forma semelhante, a entrada das mídias eletrônicas e das novas tecnologias no meio educacional - inaugurando novas fontes de informação e atraindo o interesse do aluno - parece ter invadido a quase unidade professor-aluno, na qual o professor gozou por muito tempo da posição de ser o único objeto de desejo do aluno. Muito embora o desejo desse professor seja o de "voltar ao paraíso", ele deverá aceitar o fato da impossibilidade de ocupar novamente esse lugar, ou seja, esse objeto está perdido para sempre.

O que Jonas chamou de "inversão de valores", significa que, ao professor, o aluno já não mais atribui o mesmo sentido, o mesmo grau de "desejabilidade" - pelo menos no que se refere ao lugar que o professor ocupava como uma referência, um modelo, um ideal em sua vida de aprendiz. Como afirma Lacan: "A função de quem ensina é da ordem de um papel, do lugar a sustentar, que é um certo lugar de prestígio" (1969, p.40).

A atual desvalorização do professor é um fato que, segundo Gutierra (2003), é marca da modernidade: "a desvalorização simbólica do mestre e da escola, cujo efeito tem sido a dificuldade e quase impossibilidade de ocuparem lugar de ideal essencial para a possibilidade de educação e de sua transmissão" (ibid.,p.138). Porém, existem "mestres que não sucumbem à desvalorização do professor na modernidade, apesar de reconhecê-la. A partir do valor simbólico atribuído ao lugar do mestre...conseguem exercer a função de sustentar a lei e o dever na relação 
educativa" (ibid., p.126). Talvez o professor não venha contribuindo para continuar a ser "desejável" pelo aluno.

Entender que o aluno esteja simplesmente substituindo o mestre, como fonte de saber, pelas atrativas e coloridas mídias eletrônicas, não passa de uma crença quimérica do professor, pois já se sabe, há algum tempo, "das limitações e prejuízos que soluções tecnológicas esvaziadas de propostas pedagógicas significativas podem gerar no ambiente escolar" (Giordan, 1997:7).

Vejamos agora o que nos coloca a professora Geisa:

Ele [o aluno] não quer interação com a gente se a gente estiver falando de conteúdo, mas se a gente entrar na conversa deles, a interação é perfeita. "Gente, vamos dar uma paradinha, vamos discutir tal coisa ou, como foi o final de semana...?". Então, a interação é perfeita. Agora, a partir do momento que você fala: "gente, agora chega", [o aluno responde] "ah, não professora". Então, não é que não existe a interação...existe, mas não é da forma que a gente deseja..[grifo meu]

Durante o curso de formação, a professora Geisa sempre demonstrou o quanto gosta dos alunos, gosta de estar com eles. Além de professora de química numa escola particular, ela também exerce o cargo de diretora numa escola da rede pública. No entanto, apesar dela classificar como perfeita a interação entre ela e seus alunos, se queixa de que eles não querem saber daquilo que ela tem a dizer, isto é, "[o aluno] não quer interação com a gente se a gente estiver falando de conteúdo". Então, existe um momento em que essa interação não the parece adequada, quando ela "não é da forma que a gente deseja", segundo a professora.

Tentei, naquele momento, extrair da fala da professora uma questão fundamental:

Alguma coisa falta aí, uma conexão entre o que o professor deseja e o aluno o deseja. Alguma coisa está desencontrada aí.[grifo meu]

Uma discussão com o grupo poderia ter sido iniciada nesse momento, se houvesse uma intervenção questionando a posição da professora Geisa, a partir da sua fala: o que você faz quando a interação não ocorre da forma como você deseja? 


\section{III- Abandonando o desejo de ensinar}

Para Gutierra, o lugar de mestre não diz respeito a uma profissão burocrática, mas a uma escolha marcada pelo desejo, pela "paixão de formar". (ibid.,p.126). O diálogo entre Magda, Cíntia e Geisa me faz pensar, hoje, sobre o que teria acontecido com o desejo e a paixão dessas professoras. O que se nota é um sentimento de impotência, algo de insuportável na posição de professor, que parece tornar a prática do docente uma tarefa "quase impossível".

Magda:Eu acho que dentro da sala de aula, uma das dificuldades da gente é a falta de atenção que o aluno está tendo. Eu não sei o que está acontecendo, mas ele não está conseguindo ouvir.(...) Eles têm muita dificuldade. Por exemplo, você dá uma experiência e o procedimento sempre tudo escrito, mas todas as vezes tem que falar todas as coisas. Eles não lêem. Você explica, você lê com eles. Eu tenho é a impressão de que eles estão com uma dificuldade de interpretação. Eles não prestam atenção. (...) O problema também é que o aluno não tem a linguagem, não consegue construir o pensamento. Porque ele vem lá desde a primeira série sem isso aí. Nós professores temos muita dificuldade em chegar nisso daí. $E$ o nosso aluno hoje chega com o problema da progressão continuada. É essa dificuldade, tudo junto.

Cintia: $O$ diálogo entre nós e eles como se dá na aula de fato, demanda concentração e isso ele não tá habituado. Uma vez eu li uma reportagem que falava que o aluno de um modo geral fica atento uns 10 minutos.

Geisa: Você dá aula de 40 minutos? Porque as minhas aulas nunca são de mais de meia hora...... [grifo meu]

No relato das professoras, percebemos as suas dificuldades reais - "o nosso aluno hoje chega com o problema da progressão continuada; eles estão com uma dificuldade de interpretação" -, embora elas apareçam apoiadas e justificadas sobre os alunos - "eles não lêem; eles não prestam atenção; ele não tá habituado". Também se percebe que, diante dessas dificuldades, as professoras não parecem empenhadas em encontrar saídas para a situação. Mrech (2005) alerta que "o professor tem de desencadear algo no aluno, enganchando-o desejantemente naquilo que ele ensinou, mas não assumir uma posição passiva do tipo: "Eu ensinei, os alunos aprendem se eles quiserem. A minha responsabilidade já está feita, o meu trabalho já se encerrou" (2005, p.156). 
Neste instante, abro um parêntese para relatar um episódio ocorrido recentemente numa das minhas turmas da $3^{\mathrm{a}}$. série do ensino médio, que servirá para ilustrar o que quero dizer a respeito da perda do desejo de ensinar. Para complementar uma aula expositiva sobre a forma de organização das moléculas orgânicas e sua importância na constituição da matéria viva. Sugeri que nós assistíssemos a um episódio da série Cosmos, de Carl Sagan, que fez muito sucesso na TV no final da década de setenta. Contei a eles sobre como o trabalho desse cientista havia mudado a nossa maneira de enxergar o universo, como era fascinante vê-lo fazer conexões entre os vários campos do conhecimento. Enfim, como a série havia marcado a minha adolescência e estimulado meu gosto pela ciência. Foi depois de uns dez minutos de um discurso inflamado de euforia e paixão, que ouvi a seguinte frase de um aluno:

Nossa, professora! Como é que você conseguia assistir isso? [grifo meu]

Decepcionada com a colocação do aluno, calmamente guardei o DVD que estava nas minhas mãos e disse: "abram a apostila na página 200". Mesmo havendo algumas manifestações em contrário, continuamos nossa tradicional "aula de lápis e papel”. Durante todo aquele dia só fiz amaldiçoar todos os alunos em pensamento: "eles não querem nada"; "não querem saber mais nada além daquilo que está na apostila"; "eles não merecem meu esforço"; "vou dar a eles a aula que eles merecem".

A partir dessa pequena história, hoje me faço a questão: por que eu havia desistido tão rápido do meu objetivo? Uma das respostas tem a ver com o problema já mencionado da fixação de estereótipos, no caso, do "bom professor". Os estereótipos visam a práticas e resultados idealizados; correspondem a ilusões que, obviamente, não encontrarão ressonância no mundo real. "O bom professor", entre as suas múltiplas competências e habilidades, é aquele que consegue ensinar todos os seus alunos. Já que o intento não se mostrou possível, pois a fala de um 
aluno foi tomada por todos - outro problema do estereótipo, que leva à padronização da realidade - a decisão tomada foi de não insistir.

A outra resposta tem a ver com a face narcísica do desejo que, para a psicanálise, leva o sujeito a querer que o outro pense como ele. Sujeitos presos nesse circuito tendem a acabar frustrados. O meu fascínio por Carl Sagan e pelo efeito que seu trabalho produziu fazendo marca em minha fase juvenil e despertando meu gosto pela ciência e pelo conhecimento, me levou a julgar que, da mesma forma, eu pudesse imprimi-la em meus alunos.

Um sentimento prévio de fracasso e impotência gerado nesse circuito, me levou a paralisar um movimento na direção do genuíno desejo de ensinar. 0 problema é complexo. Se por um lado, o desejo de ensinar pode aparecer camuflado, revestido de uma capa ilusória ou narcísica, por outro lado, não podemos esquecer que sem essa ilusão de capturar todos os alunos é bem mais difícil para o professor se envolver e ter iniciativas novas. Portanto, é esse desejo que o professor deve tratar com muito cuidado, no sentido de inserir uma criatividade efetiva que vá além dos seus sonhos e, ao mesmo tempo, lidar com a chegada da desilusão.

\section{IV- Compactuando com o gozo}

Na seqüência da fala da professora llda, vê-se claramente a posição que ela toma, ao meu ver, desesperada, de recuperar o mínimo controle de uma situação:

Eu falei com os alunos: "vocês fizeram um acordo comigo e não estão cumprindo". [o aluno diz]: "Professora, a gente gosta de rap. A partir de amanhã, se a gente começar a fazer todas as atividades, a senhora promete trazer o rádio pelo menos uma vez pra gente?" [a professora diz]: Olha, eu faço qualquer coisa! .. [grifo meu]

A fala de Ilda soou impactante para a professora Magda, ao repetir as palavras dela: "olha o que você falou: faço qualquer coisa!"

Imediatamente, me lembrei de um assinalamento do professor Belintane em seu texto "Instante Complexo da Vacilação na Sala de Aula", em relação aos pactos, aos acordos que os professores fazem com seus alunos e por isso alertei:

A linguagem também serve para fazer pactos... 
Mas o pacto a que me referi naquele momento, surgiu como reforço à idéia da linguagem em sua função relacional e estava revestido de um sentido positivo. Um sentido de "vamos combinar uma coisa", "vamos estabelecer juntos as regras". Mas o problema é justamente o sentido dessa "coisa" - da qual naquele momento apenas Magda se deu conta, mas que eu deixei escapar -, que traz o sentido de coisa "perversa".

O sentido perverso desse pacto está no gozo dos sujeitos. O gozo da professora llda em ver seus alunos fazendo o que ela quer e o gozo dos alunos em fazer o que eles querem, bem ao estilo "eu finjo que ensino e vocês fingem que aprendem". É o pacto entre professor e aluno onde entendemos que a via de mão dupla "faço qualquer coisa, contanto que me deixe gozar", subverte as posições do educador e do educando no processo educativo. Subverte por quê? Porque, de um lado, assassina o Mestre, aquele que deve ter, para Gutierra (2003), a função de sustentar a lei e o dever na relação educativa, destituindo-o de sua posição simbólica. De outro, reforça no aluno a imagem de "um ser que não suporta 'regras' ou 'disciplinas', disso decorrendo propostas educativas extremamente liberais ou uma hostilidade em relação ao adolescente" (2003, p.127).

$O$ ato apelativo da professora llda é apoiado pela professora Zilda:

Gente, eu tenho feito atividade com o rádio ligado com os meus meninos da Febem. Você sabe que foi ótimo! Eles ficaram em silêncio, porque tocava a música que eles gostam e eles fizeram toda a atividade com o rádio ligado! Eu pensei que a coisa fosse descambar...

De acordo com Belintane, "ao fazer nossos pactos com alunos, antes da regra clara e do indispensável conjunto de compromissos, há também o jogo identificatório inconsciente que se trama e se enrama entre o pólo do professor e a complexa teia que é uma sala de aula. Além da comunicação direta, voz-ouvido, há também essa nossa sujeição ao desejo do outro". O desejo inconsciente nesse caso pode ser entendido como o desejo do professor de ser amado pelo aluno.

Geisa:Na minha escola, à noite, cada dia da semana toca [no pátio] um estilo musical. Um dia é rap, um dia é música clássica, um dia tem aquelas dos anos 70 que eles odeiam. Mas esse pacto a gente fez desde o ano passado assim: "se vocês pegarem a merenda e devolverem os 
pratos", "se vocês não descerem antes do sinal"...então, no dia que eles aprontam eu falo: “amanhã, esqueçam a música, não tem música”. Podem vir 500 com CD, não ponho. Então, é uma troca mesmo. .. [grifo meu]

Novamente, "faço qualquer coisa" para ter o amor do outro. O apelo ao amor do outro está na base desta "troca mesmo" e nas extremidades dessa relação amorosa estão alunos e professores transformados em objetos, objetos de desejo. Como é possível o professor educar dessa posição gozosa, da posição de quem se realiza como objeto de amor do aluno?

Se ambos gozam nesse dispositivo "curto-circuitado", a energia estagnada não é capaz de "realizar trabalho". Isso quer dizer que o desejo de ensinar do professor e o desejo de saber do aluno não podem operar dentro de um dispositivo onde um e outro se satisfazem como objetos, onde o trabalho final a ser realizado - que pressupõe a existência de sujeitos desejantes - pretende-se que seja a educação.

Os pactos, acordos e trocas no teor que vimos revelados nas falas das professoras e no sentido de nossa análise, apontam para uma dificuldade que atinge a docência de um modo geral na atualidade: o não-saber-mais-o-que-fazer. Para Souza (2005), "a condição necessária para que professores e alunos recuperem o nome é de que a escola volte a ensinar. Voltar a ensinar para que a ordem seja um meio e não um fim em si mesma e para que haja um fundamento para sua aceitação, que não seja a de pedir para os alunos que apenas fiquem na escola (...) ou ainda que os professores passem dias intermináveis tentando uma forma de contrato com os alunos" (2005, p.140).

\section{V- Resgatando o valor simbólico do mestre.}

Recorrendo à síntese das respostas do grupo, interpelei a professora Geisa sobre a concepção de valor que ela agregou ao papel da linguagem na aula de ciências.

Pesquisadora: Surgiu também nas respostas de vocês, algumas coisas que eu destaquei aqui, que me parecem efeitos da linguagem. A gente faz uso da linguagem que extrapola um pouco essa idéia de comunicar, transmitir. Por exemplo, gostaria que a professora Geisa comentasse a questão da linguagem como efeito de valorizar o trabalho do professor. Geisa: Por exemplo, eles usam o termo "elemento" quando é para uma "substância", eles usam "composto" quando é "elemento químico". 
Então, eu me sinto muito valorizada quando eu percebo que eles estão usando os termos adequados. Eu acho que valoriza o nosso trabalho.(...) Acho que o conceito é o principal, no meu entender, só que aí você vai trabalhar a linguagem. É porque o trabalho vai ficar muito mais enriquecido se ele usar a linguagem adequada..[grifo meu]

A despeito do conflito que ressurge na discussão entre 0 uso da linguagem coloquial do aluno e a linguagem científica da professora, existe um valor que ela atribui ao seu trabalho que, em nossa interpretação, pode ser entendido com outro sentido. Cremos tratar-se do valor simbólico do papel do mestre que a professora quer ver enriquecido.

Embora, naquele momento, não tivesse conseguido interpretar a idéia de valor desse modo, não pude deixar de sublinhar para o grupo, o uso da linguagem extrapolando sua função cognitiva no processo de aprendizagem:

[apontando para o painel sintético] Você fez um uso da linguagem que vai além do só transmitir ou comunicar. Você está usando a linguagem para firmar uma posição que diferencia você do aluno. [grifo meu]

Mas a fala da professora llda, num momento posterior, ilustra a destituição do valor simbólico da figura do mestre, quando ela relata uma situação de sua sala de aula:

Na sala de aula são 35 alunos, alunos de 20, 18 anos, jogando aviãozinho. Fui chamar a coordenadora achando que ia resolver alguma coisa. Ela foi lá e falou umas palavrinhas mansas pra eles. Sabe de uma coisa? Não vou ficar me preocupando se a coordenação e a direção não fazem nada, não sou eu que vou ficar brigando com aluno. [grifo meu]

Destituída do seu lugar de Ideal-do-Eu, ou seja, daquele para o qual o jovem transfere suas expectativas e ideais, a professora recorre à direção e à coordenação para que as regras sejam cumpridas. Também não se trata de ficar brigando com o aluno na tentativa de submetê-lo aos seus próprios caprichos, mas de se manter firme em relação ao contrato de aprendizagem e das relações escolares, ao mesmo tempo, oferecendo espaço para que o adolescente se coloque como sujeito nesse processo. Sustentar o valor simbólico da mestria implica numa certeza ao qual o professor aferra-se em seu papel de fazer valer a lei social, "não 
para submeter os alunos ao próprio narcisismo, mas" (responsabilizando-se) "e responsabilizando-os pelas regras do processo educativo" (Gutierra, 2005,p.126).

Para encerrar o encontro, lancei ao grupo um questionamento final, ainda fazendo referência ao texto de Machado \& Moura:

Gente, só para ir fechando o texto, o que o texto trouxe para vocês de novidade? $O$ que o texto traz de novo? Qual a reflexão nova?[grifo meu]

Para essas perguntas aguardava uma "resposta certa", de modo que eu não poderia aceitar qualquer outra, por exemplo, como a da professora Magda.

Magda: Olha, eu grifei aqui nessa segunda página, "a função do professor comunicar essa mensagem e, de preferência comunicar bem, ajustando a sua forma de expressão àquela que tende ser mais adequada aos seus alunos"

Pesquisadora: Então, mas essa concepção vocês já colocaram. Agora, o que o texto provoca? Ele traz alguma provocação, ele vai um pouco além..... [grifo meu]

O tom provocativo da minha colocação era o tom de quem exigia uma determinada resposta. Só fiquei satisfeita quando as professoras Cinta e Geisa citaram os trechos que eu julgava importantes:

Cintia: Eu gostei dessa parte que ele fala que a linguagem é ponto de equívocos.

Pesquisadora: Porque era do que a gente estava falando aqui.

Geisa: [citando outro trecho] "...produzindo múltiplos efeitos independentemente das intenções...". É verdade...

Pesquisadora: São os múltiplos significados. Smolka coloca concepções de linguagem como sendo plural, polissêmica, fonte de equívocos, ilusões, mal entendidos. A linguagem não é transparente, quer dizer, aquela idéia de que o professor fala e o aluno entende e aprende...

Geisa: [citando outro trecho] "...conceber que nem sempre é a linguagem que comunica, ou seja que nem sempre o que se fala é devidamente compreendido e significado como pretendemos". [grifo meu]

Validar as respostas das duas professoras não garantiu que elas houvessem compreendido ou mensurado a importância do que estavam dizendo da mesma forma que eu, ou seja, ao fazer meu comentário, tinha em mente a colocação feita por Mrech (1999) sobre o modelo de comunicação simples no qual se baseia a transmissão pedagógica tradicional, que prevê uma leitura direta da linguagem e da 
fala. Nesse modelo existe uma crença de que os professores transmitem e os alunos aprendem.

Ainda nessa linha, os professores se lembram da leitura de um texto "As crianças e seus mundos: a história de Laura, uma professora", feita no início do curso.

Jonas: Aquela primeira apostila da professora que falou sobre astronomia é um exemplo legal disso.

Cintia: Lembra aquela vez que ela preparou aula, fez uma coisa maravilhosa e no fim... Você até prepara, é lógico, mas no meio do caminho você tem que saber que aquilo vai ser modificado, que aquilo não é uma coisa fechada, que aparecem coisas que você planejou e que não deu certo ou que não vai dar certo daquele jeito.

Zilda: Por mais experiência que você tenha, você vê que sempre vai aparecer algo diferente. Sempre vai aparecer algo que você fala: "essa é nova! eu não esperava por essa". [grifo meu]

Fechar o encontro com essas colocações significava renovar a esperança inicial de que os professores percebessem as diferentes funções e mensagens que a linguagem veicula no ambiente escolar. Parece que a discussão, pelo menos para as professoras Cíntia e Zilda, deixou clara a idéia de Lacan sobre os múltiplos sentidos da palavra, isto é, de que ela vai mais além do que se intenciona comunicar. Disse Lacan (1953-54) que, "atrás do que diz um discurso, há o que ele quer dizer, e, atrás do que quer dizer, há ainda um outro querer-dizer" (1979, p.275). E isso está refletido na conclusão das próprias professoras que acabaram por reconhecer uma das conseqüências mais importantes da ambigüidade da palavra: o componente imprevisível das situações de ensino.

\section{Depois do encontro, uma conversa com a professora Zilda}

Aproximadamente um mês depois do último encontro de reflexão aqui relatado, a professora Zilda me procurou. Na ocasião, ela me contava sobre a dificuldade que estava enfrentando com um grupo de alunos da $1^{\text {a }}$. série do Ensino Médio de uma escola particular e como tentou solucionar o problema.

\footnotetext{
${ }^{4}$ As crianças e seus mundos: a história de Laura, uma professora, do livro O Ensino de Ciências no $1^{\circ}$.grau, de H. Fracalanza et al, ed. Moderna, 1987, conta a história dos desencontros entre o que uma professora planeja e ensina numa aula sobre "os movimentos da Terra" e o que os alunos aprendem.
} 
O fato da professora ter me procurado, era um indício de um movimento que a Psicanálise preconiza como estando na base da relação entre analista e analisando e que, só a partir dele, a experiência de análise poderá se produzir: a transferência. Em análise, o paciente já traz consigo uma transferência prévia imaginando no analista o Outro que vai lhe dar o que ele quer (a solução para seus problemas). Só mais tarde deverá perceber o impossível da sua demanda.

$\mathrm{Na}$ educação ocorre algo semelhante na relação professor-aluno. O mecanismo da transferência outorga um poder ao professor que, se souber lidar com ele, poderá satisfazer, em parte, a demanda do aluno e fazer lhe restar um desejo de prosseguir sozinho na busca pelo saber. Nas palavras de Gutierra (2003), "a forma com que [o professor] lidará com esse poder que lhe é atribuído marcará um tipo de educação: ou mais voltada para o campo da alienação ou visando à separação" (2003,p.84).

É difícil precisar em que circunstâncias um sujeito estabelece uma relação transferencial do tipo que estamos descrevendo. No caso da professora Zilda e eu, podemos arriscar uma hipótese a partir da experiência relatada por Grant (1995), durante o ensino da Psicanálise na universidade, que culminaram com pedidos explícitos de ajuda por parte de alguns de seus alunos após a leitura de textos psicanalíticos. Para ela, "a simples escuta de um significante proferido pelo professor pode ser suficiente para atrair representações de ordem inconsciente e uma das saídas possíveis é a formação sintomática”. Deste modo, uma relação transferencial positiva pode se estabelecer quando "algo ocorre entre aquilo que está sendo transmitido numa aula teórica e a história individual do aluno" (1995,p.38-39).

Semanas antes da minha intervenção com o grupo de professores, havia sugerido a eles a leitura do texto "O Sujeito e a Relação com o Saber", de Charlot. Nesse texto, Charlot discute o desejo de aprender dos alunos provenientes de diferentes classes sociais sob o ponto de vista da Sociologia, da Psicologia e da

\footnotetext{
${ }^{5} \mathrm{Em} \mathrm{O}$ sujeito e a relação com o saber, Bernard Charlot (mimeografado) fala sobre as pesquisas de seu grupo que partem de uma questão sociológica - a desigualdade social frente à escola - mas que se propõem a levar em conta o sujeito, ultrapassando as fronteiras tradicionais entre a Sociologia e a Psicologia.
} 
Antropologia. Julguei o texto pertinente pois o autor, ultrapassando as fronteiras desses campos do conhecimento, consegue fazer uma aproximação interessante da idéia de sujeito singular que temos na Psicanálise.

Quando planejávamos quinzenalmente as atividades dos encontros, Malu e eu tínhamos por hábito sugerir a leitura de textos e reservar um momento para a discussão dos mesmos com o grupo. Embora tivesse consciência dos meus propósitos para um curso de formação de professores, não insisti com Malu sobre a relevância do texto de Charlot, apesar da liberdade que teria para fazê-lo e de poder contar com seu apoio. Acabei então, por sugerir a leitura como uma atividade extra e ficar na expectativa de ouvir algum comentário espontâneo dos professores, o que não ocorreu.

Só agora penso que o texto de Charlot possa ter produzido algum efeito na professora Zilda, o que me faz crer na possibilidade do estabelecimento de uma transferência positiva a partir dele. Segundo Grant (1995), algumas vezes um significante ouvido e/ou lido precipita o aluno numa vivência de mal-estar e pode fazê-lo optar por "esperar a próxima aula para falar com o professor", "esperar a próxima aula para ter uma resposta às questões que me fiquei fazendo" ou mesmo "procurar o professor fora do contexto de sala de aula" (ibid.p.40). Esta última foi a forma que a professora Zilda escolheu para buscar a solução de seu conflito interno.

Quando a professora Zilda me procurou, fazendo referências ao texto de Charlot, mostrou-me o quanto ela tinha sido capturada, a ponto de interrogar-se e tentar promover uma intervenção importante em sua prática diária, mediada pela mensagem que singularmente ela absorveu do texto. Assim Zilda relata sua situação:

A sala já estava me deixando desgastada, cansada, eu já não estava muito a fim de dar aula para os caras. Bom, eu vou ter que dar um jeito nisso aqui. Aí teve um dia que eu senti..., quer dizer, eu já não estava bem. Na sala ninguém estava querendo me ouvir. (...) Eu falei para eles que a gente ia tentar resolver. Porque primeiro me veio isso, depois teve o texto [Charlot]. Vou dar uma lida naquilo, que fala alguma coisa de social, fala de aprender, de saber, da aula. Porque eu pensei: será que é a minha aula? Em primeiro lugar você pergunta: esse comportamento é só comigo? É a química?É a professora? O quê? Eu queria saber isso. 
Intrigada, resolveu adotar um procedimento diferente do seu habitual.

Eu escrevi assim na lousa: Quem sou? Como me vêem? Porque estou? Meu comportamento é adequado? Quais os momentos na sala de aula que devem ser mais observados? Fiz o questionamento e falei para que eles refletissem e me escrevessem [em grupo] porque eu queria por escrito de todo mundo.

Uma coisa interessante foi descobrir que, à maneira como foi feita no encontro com os professores, Zilda também recolheu o questionário dos seus alunos, analisou as respostas em casa e depois as devolveu para que discutissem sobre suas próprias reflexões. Posteriormente, chamou um representante de cada grupo para se colocar perante a classe. O resultado não foi bem o esperado pois "é lógico que essas coisas mais particulares não saíram... aí eu comecei a conversar com eles".

Em sua interação com os alunos, Zilda constata a situação dos jovens que estão na escola para satisfazerem anseios familiares, sem perspectivas próprias para levarem seus estudos adiante. A maioria esperava fazer uma faculdade como uma forma de se dar bem na vida e com isso atender a um desejo da família. "Eu fiquei sabendo de coisas particulares de alunos que se sentem rejeitados". Todo esse quadro, para Zilda, refletia na falta de compromisso com a escola e no comportamento inadequado dos alunos em sala de aula.

Uma das coisas que eu usei depois de ter lido o texto, um momento que fala aqui, em relação ao "o homem não nasce pronto", e para isso ele vai precisar buscar algumas coisas, né? É esse aprender, essa vontade de aprender, não só de conhecer mas de aprender, da necessidade disso. Conversei muito com eles e muitos deles ficaram interessados. Eles também concordaram com o que eu estava falando.(...) Eu nãa dei o texto para eles, eu estava só transmitindo... eu falei para eles do autor... falei para eles principalmente da postura do não aprender, e que todos eles queriam conhecer, queriam saber, todos eles eram extremamente curiosos, mas só curiosidade, eles não tinham interesse de dar continuidade naquele conhecimento. [grifo meu]

Interpretamos que o significante desejo de saber apresentado à professora pelo texto, tenha enganchado a professora, que passou a se mobilizar para resolver o seu problema, a querer saber mais sobre a situação.. Parecia estar tão 
convencida que tentou até mesmo envolver a direção da escola na questão: "sabe que eu fiz? Eu xeroquei o texto, mandei para o diretor da escola, mas ele não fez nenhum comentário. Eu esperava que ele fizesse algum comentário".

Reparemos que a professora Zilda esperava que o diretor fizesse algum comentário sobre o texto de Charlot, da mesma forma que eu também fiquei à espera de alguma manifestação dos professores do grupo. A postura de ficar à espera do Outro, seja de um comentário, de um reconhecimento, ou mesmo de uma solução, pode levar o sujeito a um recuo diante do desejo.

Tal recuo do sujeito vem revelar um estado de baixa auto-estima, de quem aprendeu a obliterar com o Outro materno o seu próprio desejo. Segundo Lacan, enquanto uma criança lutar para ser o objeto de desejo da mãe, se perguntar "o que ela deseja de mim", o ser do sujeito (desejante) para ela não poderá advir. Nesse momento, a criança permanece alienada, dependente, à espera da oferta de amor, de reconhecimento, de aprovação da mãe (Outro). Insistir nessa posição, coloca o sujeito sempre em demanda, privado em sua iniciativa por buscar orientado pelo próprio desejo. Se a criança fracassa em tentar ser tudo para a sua mãe (Outro), um(uns) Outro(s) poderá(ão) surgir em sua vida (professor, diretor, marido/esposa, analista, juiz, Deus) de modo que a demanda, inconscientemente, continua.

$\mathrm{Na}$ medida em que o Outro é grande, crescendo em importância e poder, perguntas como: "Será que é a minha aula? Esse comportamento é só comigo? É a química? É a professora? O quê? Eu queria saber isso", ou seja, "o que ele quer de mim", não cessam de surgir. Mas o fato interessante é que a postura de indiferença do Outro diretor da escola em relação ao problema da professora, que poderia levála a paralisar em seu desejo, resultou em efeito contrário, já que Zilda resolveu enfrentar sozinha, veremos de que maneira, a sua questão.

O que nós vamos poder estar mudando disso tudo? Porque do meu lado, eu tenho interesse, não só de passar a informação, mas que vocês aprendam, que vocês façam uso do professor, eu estou me disponibilizando. Se tiver um momento que vocês fizerem alguma pergunta que eu não souber responder, logicamente que isso vai ser muito interessante, porque eu também vou buscar formas de estar estudando, trazendo a informação. Então isso vai ser ótimo. Aquilo que 
eu não souber, eu deixarei de estar respondendo naquele momento, mas vou estar buscando informações $e$ isso vai fazer com que todo o grupo cresça.(...) Então eles comentaram comigo que seria bom eu estar realizando um experimento na sala de aula [embora os alunos tivessem aulas de laboratório em outro período]. Então, no próximo ano, nessa escola que tem laboratório, eu vou estar levando os materiais fáceis para poder transportar e estar fazendo experimentos na sala de aula. [grifo meu]

A posição que Zilda assume diante das demandas dos alunos nos parece ser a da boa mãe, aquela que protege, que está pronta para atender as necessidades da criança. Zilda encarna o Outro materno alienando-se no desejo da criança e demandando em troca o seu amor. Se a criança tem constantemente suas necessidades antecipadas pela mãe, não há espaço para a instauração de uma falta e conseqüentemente de um desejo. "Por isso, o Outro materno precisa mostrar algum sinal de incompletude, falibilidade, ou deficiência" (Fink, 1998, p.76) para que a alienação dê lugar à separação. Apesar de dizer-se incompleta, no caso deles "fazerem alguma pergunta que não souber responder", Zilda não se mostra como tal, pois vai "buscar formas de estar estudando, trazendo a informação". Em outra situação, vai "estar levando os materiais fáceis para poder transportar e estar fazendo experimentos na sala de aula".

Embora Zilda não criasse muitas expectativas quanto a alcançar uma mudança satisfatória na postura dos alunos - pois ela mesma admitiu "que com jovens, você tem essa combinação assim... no momento da discussão, passou dois minutos depois..." - a professora se surpreendeu com alguns resultados que obteve depois da sua intervenção.

Isso foi muito bom porque permitiu que a minha relação se tornasse mais próxima, principalmente dos casos que eu precisava estar atingindo. Esses garotos passaram a me ver, até me olhar de uma forma diferente. Hoje eles já me encaram. Para você ter uma idéia, esses meninos vieram sentar na primeira fila. Dois vieram sentar na frente da minha mesa. Então eu achei isso muito bom porque houve uma aproximação da relação. Hoje esses alunos são os que mais têm tido participação na aula.

Depois que a professora percebe o movimento dos alunos em sua direção, ela não quer perder a chance de "abocanhá-los". Lacan, num trecho do seminário 17, expõe da seguinte forma o desejo da mãe: "um grande crocodilo em cuja boca 
vocês estão - a mãe é isso. Não se sabe o que lhe pode dar na telha, de estalo fechar sua bocarra" (1992, p.105). Vejamos como isso se dá quando a professora relata o episódio subseqüente, no qual o grupo de alunos "que realmente traziam problemas para a sala, alunos na maioria com potencial, inteligentes, meninos que não têm dificuldades de aprendizagem", resolve fazer um trabalho de química para a feira de ciências da escola:

Aí eu pensei: eu não sei o que passar para esse pessoal, porque não poderia usar fogo. Então me falaram: "porque você não faz a cromatografia?". Aí eu dei material para eles, passei a bibliografia, até o que eu tinha xeroquei para eles. Na sexta-feira nós tínhamos marcado um horário, embora eu não fosse para escola, eu estaria lá ajudando. Aí eu levei mais material escrito e levei até material de cromatograma pronto para que eles pudessem usar aquilo. [grifo meu]

Mais uma vez, a boa mãe "fecha a sua bocarra": escolhe o tema do trabalho, fornece material bibliográfico, executa o experimento previamente e até disponibiliza horários que habitualmente não dedica para a escola. A fala de Zilda, "que vocês façam uso do professor", pode ser interpretada agora como um desejo inconsciente de "que vocês façam de mim seu objeto".

Ao final, Zilda fica satisfeita, mas desconfia da opção espontânea do grupo dos alunos - "que realmente traziam problemas para a sala, alunos na maioria com potencial, inteligentes, meninos que não têm dificuldades de aprendizagem" - por escolherem a sua disciplina para um trabalho na feira de ciências:

Mas eu não sei por quê. Depois eu até pensei: acho que eles queriam me agradar porque ninguém ali precisava de nota [de química], entendeu?

Em seu esforço para ajudar os alunos Zilda acaba insatisfeita porque "eles não executaram o trabalho embora tivessem todo o material. A cromatografia é muito fácil, tudo material simples, nem usaria nada do laboratório. Então não era esse o motivo que estava impedindo". A frustração foi o preço pago pela professora pois, o Outro materno com sua bocarra, na tentativa de ser tudo para a criança, não deixou espaço para que o aluno criasse suas próprias soluções. 
Diante desse episódio e da fala da professora, perguntei-lhe "como você poderia verificar se eles estavam querendo agradar ou se estavam querendo aprender?" A resposta que eu obtive foi:

Eu estou a fim de perguntar para eles numa boa: "o que levou o grupo a querer fazer a feira de ciências na área de química, sabendo que vocês não têm problema de nota?" Eu estava querendo perguntar sem rodeios, para ver o que eles me respondem, por ser o grupo mais honesto, como eu te falei. [grifo meu]

A indagação que dá fechamento a essa conversa, demonstra a essência da proposição do nosso trabalho. Ao invés da professora buscar suas respostas no outro, um questionamento sobre si mesma, sobre as posições subjetivas que ela assumiu, as satisfações e insatisfações inconscientes que subjazem às suas ações na sala de aula, talvez pudesse lhe revelar alguns elementos que a auxiliasse no encontro de suas próprias respostas.

\section{Algumas considerações}

Desvelar e interpretar as posições subjetivas dos sujeitos, nos permitiu tornar evidentes a influência que as mesmas exercem nas práticas docentes. Contudo, foi a minha experiência como formadora que me possibilitou apontar alguns caminhos que se podem percorrer na realização dessa tarefa, visando ampliar o olhar dos cursos de formação continuada de professores que têm como proposta a prática reflexiva.

A tarefa de buscar e interpretar essas posições, não é nada trivial, pois exige algumas condições especiais por parte de todos os sujeitos envolvidos, no caso, professores e formadores. Da minha parte, como formadora, exigiu-se, em primeiro lugar, uma necessária disposição e abertura para formação de um vínculo com seus alunos-professores, que só foi possível alcançar depois de sair da posição recuada de coadjuvante e partir para a interação com o grupo. Esse movimento pode ser interpretado como uma decisão por enfrentar a minha insegurança - fruto das imagens idealizadas de formadora e pesquisadora construídas a partir dos Outros Malu e Academia - e assumir o desejo de formar e pesquisar. 
Também foram necessários preparo e disposição para uma escuta diferenciada das falas dos professores. Uma escuta com profundo interesse e atenção pela pessoa do professor. A atenção flutuante, isenta de pré-julgamentos conscientes que prepara o ouvinte para fazer intervenções adequadas em certos momentos das fala dos sujeitos, se mostrou um exercício complexo. No meu caso, as questões trazidas pelos formandos eram muitas vezes semelhantes àquelas enfrentadas com meus próprios alunos. Na tentativa de ajudar os professores a confrontarem suas dificuldades, acabava esbarrando na minha própria condição de docente. Mas, se por um lado, os elementos de identificação que existem entre um formador e os professores podem tornar a tarefa de formar mais difícil, por outro, eles se mostram frutíferos para o avanço da própria prática do formador, uma vez reconhecidos e questionados.

O uso da técnica da livre associação nos mostrou sua eficácia por induzir à saída dos professores do campo do discurso dominado por uma linguagem padronizada e previsível - a exemplo das respostas escritas ao questionário objetivo -, dirigindo-os para uma situação onde a fala mais espontânea permitiu que se colocassem subjetivamente. A nitidez desses dois momentos do discurso dos sujeitos surge quando se nota o deslocamento das concepções dos professores a respeito do papel da linguagem nas aulas de ciências. Inicialmente, com uma função meramente técnica e instrumental, voltada à aprendizagem de conceitos científicos, a linguagem vai adquirindo novos sentidos no campo da subjetividade, das interações com o outro e na formação do vínculo professor-aluno.

As interpretações dadas às posições subjetivas dos sujeitos, são indicativas de um material que, exposto ao questionamento, tem a intenção de ser trazido à consciência para os mesmos, na esperança de despertá-los para uma reflexão dessa natureza. Sobre os efeitos dessas interpretações nos sujeitos, funcionam como no caso da análise. Segundo Forbes, é impossível "avisar um analisando que em determinado momento irá surpreendê-lo, inquietá-lo, ou angustiá-lo, pois nem mesmo o analista sabe que efeitos produzirá sua posição (...) Ao analista não resta outro recurso senão se responsabilizar pelo seu ato" (1999,IV,p.2). 
Mas a surpresa não caminha apenas na direção do analista para o analisando. De uma forma análoga, um exemplo de uma grata surpresa foi-me dado pela professora Zilda que, ao me trazer um conflito de sua sala de aula, mostrou-me o resultado de uma transferência positiva, ao enganchar, de modo singular, seu conflito interno com a mensagem do texto de Charlot e mobilizar seu desejo de saber na direção da sua resolução. 


\section{A EXPERIÊNCIA DA FORMADORA MALU}

A formadora Malu completou o curso de licenciatura em Química numa Universidade Federal de Minas Gerais e atuou como professora do ensino médio na Rede Pública e particular. Durante a graduação, também participou dos encontros de um grupo de estudantes, dentro da Universidade, procurando aperfeiçoar seus conhecimentos em Química e Educação, onde teve oportunidade de desenvolver e trabalhar com materiais que contemplavam uma proposta alternativa dentro do ensino de química. Desde o início de sua carreira docente, Malu adotava materiais e estratégias de aula não convencionais, obtendo relativo sucesso nas escolas em que lecionou. Malu admite não saber trabalhar da forma tradicional, orgulhando-se do resultado de seu trabalho: "tanto é, que eu fiz uma substituição numa escola e foi um arraso!"

$\mathrm{Na}$ época dos eventos que analisaremos, como já o dissemos, Malu estava cursando o mestrado em Ensino de Ciências numa universidade paulista e pretendia explorar parte da nova experiência como formadora para elaborar sua dissertação. Seu orientador havia lhe proposto que organizasse um curso de capacitação para professores de química, aproveitando o material "Fármacos: um estudo químico, biológico e social", que ela desenvolvera e aplicara, no ano anterior, para seus alunos do ensino médio.

Esse curso, então denominado "Encontros de Reflexão e Ação sobre a Sala de Aula de Química", foi oferecido e ministrado na Faculdade de Educação de uma universidade paulista ao longo do ano de 2004, totalizando 30 encontros semanais (60 horas). Como proposta de formação continuada, o curso visava atender os seguintes objetivos:

- Oferecer oportunidades para aperfeiçoar e refletir sobre a prática de sala de aula;

- Discutir os conceitos químicos presentes em temas de interesse social como saúde, meio ambiente e novos materiais;

- Disponibilizar acesso a propostas de ensino envolvendo computador, internet e vídeo; 
- Debater as repercussões das pesquisas sobre educação em química na sala de aula;

- Formar grupos de trabalho para elaborar, aplicar e refletir sobre atividades de ensino.

Das vinte e cinco vagas disponibilizadas, dezenove foram preenchidas com professores de química (em sua maioria) e biologia do ensino médio. É importante considerar que não foi oferecido aos participantes nenhum tipo de incentivo, como bolsa de estudo, ajuda de custos ou abono de ponto, vantagens que são comuns nos cursos dessa natureza. Os professores receberam apenas um certificado de participação gerado pela universidade após a conclusão do curso.

De acordo com a proposta de formação e com objetivos acadêmicos de Malu, fez-se a divisão dos trabalhos em dois semestres:

10. Semestre. A proposta era discutir com os professores a concepção e a articulação dos três elementos que organizavam o eixo principal do material de Malu: tema, conteúdo e atividade. $O$ estudo desses elementos apoiava-se em leituras de textos sobre educação em química, na análise de "episódios de ensino"com base em trechos de aulas de outros professores gravados em vídeo - e na análise do próprio material de Malu. Durante os encontros, os professores receberam a tarefa de desenvolver uma atividade utilizando a estratégia do "debate" em sala de aula, com escolha livre do tema. A estratégia do debate foi amplamente utilizada por Malu no seu material "Fármacos", de modo que explorar o uso desse recurso didático pelos professores, era parte de seu objetivo de pesquisa. Os professores aplicaram a atividade em suas respectivas escolas e trouxeram os registros em vídeo para discussão no grupo.

20. Semestre. A proposta para os professores era planejar e aplicar em sala de aula um Módulo de Ensino, também com escolha livre do tema, com base nos três elementos discutidos no semestre anterior, o que exigia um esforço bem maior do grupo em comparação às tarefas já desenvolvidas. O estudo dos Cadernos Temáticos da revista Química Nova na Escola, algumas atividades experimentais, no laboratório de química e pesquisas no ambiente da Internet, serviram de 
subsídios para a construção do Módulo de Ensino. Da mesma forma que no semestre anterior, a maior parte do planejamento ocorreu durante os encontros.

Observemos que este curso, a partir do título, dos objetivos traçados, dos materiais (textos e episódios de ensino) selecionados, até as atividades programadas, visava claramente uma reflexão dos professores a respeito de suas próprias práticas. Acontece que as práticas docentes de interesse - já que as linhas centrais do curso estavam pré-estabelecidas por Malu e seu orientador - seriam aquelas voltadas para as articulações entre os três elementos que citamos, mais a estratégia do debate como recurso didático. Isto quer dizer que, diante de uma preocupação restrita aos aspectos tecnicistas e metodológicos do ensino, não me pareceu haver lugar, pelo menos inicialmente, para um tratamento mais subjetivo das questões docentes.

\section{Um pouco mais sobre Malu: uma surpreendente revelação}

Uma imagem idealizada de Malu, foi sendo construída, à medida em que observava suas ações com os professores, nas quais demonstrava segurança e firmeza, ao mesmo tempo, leveza e descontração. Na medida em que a troca de idéias se intensificava, durante a discussão dos problemas práticos inerentes ao planejamento de um curso para professores, acabávamos também expondo nossas dificuldades pessoais em lidar com essa tarefa. A imagem da Malu, segura de si, leve e descontraída diante dos professores, começou a dar lugar, nos bastidores, a uma figura um pouco mais angustiada, preocupada e cercada de incertezas. A imagem idealizada de Malu plena, rompia-se e dava lugar a uma outra, dividida.

À medida em que discutíamos sobre nossas expectativas, sobre as nossas dificuldades na elaboração das atividades, assim como o desempenho do grupo de professores diante das tarefas, percebia-se que Malu buscava cada vez mais a minha colaboração, pedindo e acatando minhas sugestões. Desse modo, aumentavam os indícios que revelavam a efetiva inexperiência de Malu como formadora. 
Entretanto, o que me chamou a atenção foi esse contraste entre o espírito desarmado, solto, leve, descontraído da formadora na condução das atividades e a tensão que ela deixava transparecer, aos poucos, nos momentos de reflexão sobre a própria prática. Como conciliar esses dados? De um lado, a insegurança, a falta de experiência que pareciam suficientes para comprometer seu desempenho e de outro, porém, uma ação que caminhava na direção oposta, que não delatava sua fragilidade.

Estávamos trabalhando juntas havia mais de seis meses, quando the propus a primeira entrevista. Nesse momento, eu já havia realizado minha intervenção com o grupo e experimentado, durante minha experiência, o sabor dos meus conflitos pessoais. A opção por investigar a posição subjetiva do formador no exercício do seu papel, se firmou a partir de então.

Diante desses dados, minha hipótese era a de que a presença de alguns elementos, atuando de maneira inconsciente para Malu, estivesse na origem dos pontos de tensão e também influenciasse sua serenidade. Nossa tentativa será de encontrar tais elementos na fala de Malu, de onde possamos interpretar, sempre com o apoio do referencial psicanalítico em Freud e Lacan, a disparidade entre suas ações e reflexões.

Na primeira entrevista, pude descobrir que, para a regência do curso, Malu esperava contar com o apoio de seus colegas da pós-graduação e, inclusive, de seu orientador. No entanto, diz ela:

Quando eu cheguei em fevereiro que eu vi que era só eu ... aí eu não tive tempo nem de pensar, preparar, como é que eu tinha que fazer. Eu falei [para o meu orientador]: Você me acompanha? Aí ele veio só nas primeiras reuniões. Quando eu vi que eu tinha que assumir o grupo, eu fiquei preocupada, meio tensa mesmo. [grifo meu]

E para reforçar a minha surpresa, Malu declara em seguida:

Nunca tinha pensado em trabalhar com professores. Nunca tinha trabalhado. Eu já tinha participado de cursos de formação, como aluna. Eu não tinha nada de preparação, de concepção, nunca tinha pensado em formação, em como trabalhar com professores, nada! [grifo meu]

Durante a entrevista, aos poucos, Malu começa a revelar parte das aflições que soube ocultar, do início do curso até então: 
A única coisa que eu fiquei pensando: será que eles [os professores] vão ficar questionando muito? Se eles começassem a perguntar de teorias da educação, eu acho que ia me enrolar. Como eu vou dar conta disso? Como que eu vou dar aula de teoria?Eu acho que eu não tenho essa condição de chegar, entrar num curso e dar teoria da educação, eu não tenho esse conhecimento.

Nessa fala, Malu declara sentir-se pouco preparada para a tarefa, apesar do seu orientador ter participado do planejamento inicial e dos primeiros encontros para dar seu apoio às iniciativas da formadora. Este ponto de tensão, que Malu só revela em suas reflexões, está localizado em sua falta de domínio em relação a determinados conteúdos que, eventualmente, poderiam ser abordados e exigidos pelo grupo durante o curso. Malu demonstra um receio em mostrar falhas nesse sentido.

\section{As Angústias de uma Formadora Inexperiente}

A partir dessas revelações, não pude deixar de comentar com ela as minhas impressões sobre sua postura de formadora. Malu tenta uma explicação:

Acho que talvez por isso, que parece que é solto, mas que no fundo deve ser isso, falta de planejamento mesmo. [grifo meu]

O que para mim parecia solto, no sentido de descontraído, para Malu era a expressão de sua falta de preparo. Recordo-me de que, por várias vezes, ela manifestou sua insatisfação por sua condução, queixando-se principalmente de seu planejamento pouco detalhado.Enfim, parecia-Ihe não ter um controle suficiente $\mathrm{e}$ isso provavelmente a deixava insegura, até por permitir espaços para desvios do eixo do curso.

Malu me relatou também uma outra angústia que, em nossa interpretação, era gerada, inicialmente, pelo confronto com um ideal de formação elaborado, imaginariamente, a partir das expectativas de um formador experiente, no caso, seu orientador e da pouca confiança em si mesma.

Nos primeiros dias eu estava bem nervosa e estava preocupada em seguir o conteúdo, o cronograma.(...) Eu estava pensando como que o meu orientador gostaria que aquela aula acontecesse e não como eu levaria a aula. [grifo meu] 
Porém esse ideal de controle não operava durante a atuação com os professores, pelo menos, de um modo perceptível. Sem dúvida, Malu tinha como sua referência o orientador, para o qual ela prestava contas conscientemente em suas reflexões e, provavelmente, de maneira inconsciente, na sua atuação. Nesse sentido, o orientador representava para ela o Outro da psicanálise, ou seja, a referência implícita da criança, introduzida quando de sua entrada na linguagem. Inicialmente, seus representantes são os pais, posteriormente qualquer instância social que a capture. Ao assujeitar-se ao Outro, a criança torna-se um sujeito da linguagem. Nesse caso, ao assujeitar-se ao orientador, ao considerá-lo como seu guia e seu modelo implícito, Malu ganhava cidadania na Academia. Entretanto, esse era o primeiro passo para alcançar a autonomia. Parece-nos possível interpretar que o orientador, de alguma forma, conseguiu ajudá-la a avançar, revertendo o processo de dependência inconsciente: ao depositar toda confiança nela, deixandoa assumir a tarefa sozinha, conseguiu que ela imprimisse um toque pessoal ao curso, descolado de um ideal que ela supôs estar no seu orientador.

Tanto você viu que ele [orientador] veio, participou de dois ou três encontros, depois saiu fora. Eu falei: vou levar do jeito que eu sei.

É interessante notar que a operação realizada pelo orientador não constitui uma regra para ajudar o orientando a tornar-se mais autônomo, a adotar um estilo próprio. O "abandono" dele, ao invés de ser interpretado como um sinal de confiança, poderia ter tido um efeito paralisante para Malu e um convite a não se afastar do planejamento e da imitação do orientador. De fato, esta preocupação por um longo tempo ocupou a reflexão de Malu, gerando um descompasso entre os sentimentos que acompanhavam a realização da docência e a sucessiva reflexão. O efeito de assujeitamento é bastante comum em docentes que iniciam um contato sistemático com a literatura sobre educação e pretendem entrar na Academia. Em alguns casos, também aparece a divisão entre a reflexão baseada no ideal e a atuação baseada na intuição docente (Sudan, 2005).

Se, por um lado, podemos interpretar a tensão confessa de Malu com base nos argumentos que apresentamos, por outro, o que ela deixa escapar em suas 
ações demonstra, para nós, também a atuação de outros elementos não conscientes, desta vez, interferindo a seu favor. Provavelmente, o afastamento de seu orientador tenha sido um fator de incremento para a auto-confiança de Malu. Porém, suas reflexões posteriores em entrevista, além das falas informais, mostram tal fato não ser suficiente para explicar sua sustentação diante das demandas do grupo ao longo do curso.

Recordo-me de um comentário informal, no qual Malu revelara sua confiança na minha competência, para quem delegou algumas intervenções nesse sentido durante o curso. Imaginamos que, pelo fato dela saber do meu envolvimento com capacitação de professores no meu período de mestrado e por estar cursando doutorado naquele momento, eu estivesse representando alguma espécie de autoridade presente, um Sujeito Suposto Saber, psicanaliticamente falando. Dessa forma, eu estaria ocupando um lugar imaginário de alguém a quem ela poderia recorrer, alguém que supostamente saberia como ajudá-la enfrentar situações conflituosas.

Durante a fase inicial de planejamento do curso, que eu acompanhei de perto, Malu não pontuou nenhuma preocupação especial quanto ao grupo de professores que estaria freqüentando o curso. Mesmo sobre sua preocupação em não conseguir dar conta de conteúdos específicos, caso os professores o exigissem, Malu não me deu pistas no início, fato que me surpreendeu em revelação posterior. Seria esperado que a formadora apresentasse suas expectativas ou conceitos prévios em relação aos professores, a partir dos quais tentasse elaborar planos de ação, principalmente de defesa. Estou me referindo as minhas impressões como aluna em cursos de formação, além das minhas observações durante o mestrado, constatando as queixas freqüentes que ouvia dos professores-aprendizes. Essas queixas normalmente são expressões das resistências de alguns professores em relação às estratégias, aos conteúdos e até aos discursos acadêmicos que se veiculam nos cursos de formação.

Notando em Malu a ausência de tais planos de defesa e questionando sobre suas expectativas iniciais em relação ao grupo de professores, recebi com surpresa sua declaração: 
Sobre concepções dos professores, eu não tinha idéia, por exemplo, dessa questão das reclamações. A gente não tinha nos grupos, nem nos HTPCs, nem na Universidade, durante os dois, três anos que eu fiquei lá dentro, não tinha essas reclamações não. Eram professores de escola pública, de escola particular. O que era discutido era tudo aceito, tudo tranqüilo, a gente não tinha esses embates: "isso aí não dá pra aplicar, não dá pra fazer".

Nessa fala, Malu se recorda dos grupos de formação dos quais participou como aluna nos tempos em que permaneceu ligada à universidade e dos quais parece ter trazido experiências altamente positivas. Pensamos que essas experiências permitiram que ela construísse uma visão a respeito de professores muito otimista e favorável ao seu trabalho posterior como formadora de professores. Mrech (1999) ressalta que um discurso prévio que antecede o contato do sujeito com a realidade com a qual ele vai lidar é criado no imaginário dos sujeitos e, junto com ele, formas de ação socialmente determinadas que estruturam o que escutar, o que dizer e o que fazer em um determinado momento. Entendemos portanto que, para Malu, o fato dela não ter tido uma experiência anterior que the marcasse negativamente, tornou desnecessário que elaborasse previamente esquemas de defesa ou discursos para lidar com os professores que iriam chegar.

Foi com a mesma surpresa que Malu recebeu minhas concepções pessoais a respeito da postura de queixa que havia observado em professores que freqüentavam cursos de capacitação, pois as mesmas não faziam parte do universo com o qual mantivera contato.

Eu não consigo nem entender que concepções são essas, que problema é esse que eu nem sei. [Essas queixas apareciam] durante o curso?

Realmente, observamos que nosso grupo de professores não fazia queixas sistemáticas em relação ao curso, embora percebêssemos em alguns professores dificuldades e resistências pessoais quanto à execução das tarefas propostas.

Além da ausência de pré-concepções negativas a respeito dos professores, Malu trouxe para sua prática outras vivências que funcionaram, a nosso ver, como modelo implícito para o seu curso de formação. O seguinte relato de suas experiências como aluna, suscitou-me essa possibilidade:

Então a gente não tinha coisas fechadas também. E eu achava legal isso de ter um grupo de professores que a gente trocava idéias e funcionava. 
Era uma aula que a gente ia lá para bater papo, falava de sala de aula, falava de aluno, falava de concepções alternativas e resolvia alguns problemas ali.

A falta de um planejamento mais sistematizado, que, segundo Malu, seria a causa de sua conduta mais solta, remete ao modelo de formação a que foi submetida e que resultou, para ela, numa experiência satisfatória. Malu não se dá conta de ter se utilizado de um modelo que "deu certo" e se surpreende com essa possibilidade:

Não, não percebi isso não. Você está falando isso agora e o que me veio em mente foi isso, mas não foi intencional.

A conduta de Malu aparece refletida nas opiniões das professoras Geisa, Magda, Zilda em avaliações escritas individuais realizadas ao final do $1^{\circ}$. e $2^{\circ}$. semestres do curso:

Magda: Quero aproveitar para enfatizar o profissionalismo com que vocês [formadoras] nos tratam, escutando e levando em consideração as nossas ansiedades e dúvidas. O diferencial desse curso foi a liberdade que nós tivemos de programarmos um projeto.

Geisa: Elas [formadoras] têm facilitado a convivência e as discussões, criando um clima de cordialidade e ambiente muito agradável, no qual todos podem expor suas idéias e trocar experiências.

Zilda: As capacitadoras e os colegas do grupo tornaram-se parceiros e colaboram entre si. Isso é muito bom para o crescimento profissional de todos. O curso também proporcionou troca de experiências entre colegas e a somatória de estímulos para a continuidade dessa jornada. O curso possui um diferencial que é o caminhar de acordo com nossas realidades.

Apesar do modelo implícito, Malu estava consciente de sua maneira de lidar com os professores:

O professor teve toda a liberdade de estar fazendo o planejamento dele. Primeiro a gente escutou, ouviu como eles planejam, como eles desenvolvem. Por exemplo, a diferença do professor Davi e da professora Magda, eu percebo a diferença. Da professora Gilda eu não percebo muito não. Eles trabalharam o mesmo projeto mas cada um na sua realidade.

A liberdade, a troca de experiências, a parceria, a colaboração, a escuta, o clima cordial, o ambiente agradável, o estímulo, o caminhar de acordo com a realidade, salientados pelos professores participantes, interpretamos serem resultados não apenas de sua crença consciente na lida com os professores, mas 
também fruto de seu modelo de formação, ao que ela se remete durante as entrevistas:

A gente ficava ali discutindo o que o aluno pensava, como pensava e como que a gente podia responder. Ali, a primeira vez que eu fiz foi interessante, a segunda vez, porque depois saí para dar aula na escola pública e fui para dentro da universidade, começou tudo de novo, chegou muita gente de fora. Então, eu já dava aula com aquele material, e mesmo assim fui participando do curso. Aí eu ficava auxiliando os outros colegas. Não tinha planejamento nenhum, não tinha nada. A gente ia seguindo o livro. Algumas vezes eles falavam: "semana que vem cada um traz um experimento" e aí dois ou três por dia traziam um experimento. Tinha gente que chegava e dizia: "olha, hoje eu trouxe, fiz isso daqui e deu certo". E a gente ficava ali discutindo. Então deu essa maleabilidade ali.

As falas anteriores de Malu revelam as mesmas práticas de parceria, colaboração, troca de experiências, clima cordial, instalados em seu curso e de seu tempo como aluna em formação. A oportunidade dada aos professores de caminharem de acordo com a realidade, entende-se como resultado da percepção da formadora que ficou atenta às singularidades de cada um. A realidade precisa ser entendida aqui sob dois aspectos: uma delas se refere ao mundo concreto, material, externo ao sujeito, que no caso representa a escola, os alunos, a sociedade da qual eles fazem parte. Em psicanálise, chamamos esse quadro de realidade material, social ou externa, na concepção freudiana. A formadora tem noções dessa realidade, não apenas por meio da fala dos professores mas também porque fez contato com ela quando exerceu sua atividade como professora de escola pública. A outra noção de realidade, a psicanálise chama realidade psíquica, que é a leitura que cada sujeito faz da realidade concreta. Por ser uma leitura particular dos sujeitos, essa é mais difícil de ser capturada. A formadora parece estar atenta aos sujeitos, ouvi-los, porque embora eles possam compartilhar de uma mesma realidade exterior, cada qual tem seu modo particular de abordagem e posicionamento frente a ela.

Um outro detalhe que nos permite entender os efeitos de sua conduta na relação com os professores é sua experiência anterior com o ensino médio. Ela tinha produzido e aplicado para seus alunos o mesmo material sobre o qual apoiava o seu curso. Isso tinha permitido desenvolver um conjunto de atividades 
consideradas interessantes pelos alunos: debates, leitura, experimentos e vídeos acerca dos conteúdos químicos, biológicos e sociais associados ao material.

Convidei uma turma de $3^{\circ}$. ano da escola para um mini-curso como se fosse uma revisão de fim de curso. Foi bom para eu testar o módulo e ver o que funcionava ou não.

Malu considerava sua experiência um sucesso e acreditava que seus professores poderiam aproveitar com vantagem do mesmo material em suas salas de aula. Essa convicção, além de gerar confiança na formadora, também ia ao encontro de uma expectativa dos professores do curso que, desde o início, manifestaram sua crença na possibilidade de apreender um modo "correto" de ensinar, possivelmente corporificado num método ou numa "receita". Essa suposição, bastante comum nos professores que freqüentam cursos de capacitação buscando metodologias novas, os leva a uma outra crença, a de que os formadores possuem o domínio desse conhecimento. Nesse caso, a posição de Sujeito Suposto Saber, também foi assumida pela formadora, ou seja, aquela que imaginariamente seria a depositária do saber que deveria resolver os problemas dos professores. Essa identificação é necessária no início do processo para que se dê o movimento do sujeito na direção do aprender. No entanto, a seu momento, o professor deverá perceber que lhe cabe encontrar seu caminho pessoal, dissociar-se do saber do formador e tornar-se autônomo.

Malu articulou as atividades do curso, em sua primeira metade, com o material que ela produziu mediante discussões acerca do tema (utilização de um medicamento fitoterápico) e das atividades que poderiam ser realizadas. Ao apresentar o seu material para o grupo, a formadora parecia ter em mãos a tão esperada "receita", o conhecimento que supostamente estaria depositado no Sujeito Suposto Saber. Assim, o material serviu como um modelo, porém Malu teve o cuidado de não impor sua adoção em sala de aula por parte dos professores, mantendo simultaneamente o clima de liberdade e de segurança. Isso permitiu que as professoras Cintia (biologia) e Magda (química), trabalhando na mesma escola, resolvessem aplicá-lo com seus alunos sob a supervisão de Malu. 
Trouxemos elas para o curso de formação, apresentamos a nossa proposta, negociamos as atividades. Elas não queriam trabalhar com trechos de filmes - foi a única coisa que foi imposta - levei para elas os trechos, não levei o filme inteiro e elas usaram, gostaram. Mas foram elas que fizeram o planejamento, a divisão de aulas, elas que fizeram tudo, quantas turmas elas iriam usar, quais os dias, tudo isso foi feito por elas, elas que organizaram. E eu estava lá meio que... tentando, fazendo com que elas cumprissem.

Malu não deixava de questionar e discutir com o grupo os problemas por eles enfrentados e as possíveis alternativas para solucioná-los. Compartilhava suas próprias dúvidas, incertezas e questões de sala de aula. Talvez tenha surgido aí uma identificação do grupo com a formadora e por isso o depoimento da professora Zilda que sentiu as formadoras como parceiras e colaboradoras do grupo. Cintia e Magda puderam vivenciar suas próprias questões ao aplicar o material e mostraram-se satisfeitas com o resultado.

Cintia: Eu e a Magda tivemos a sorte de aplicar o projeto da Malu em nossa escola. Foi uma experiência muito prazerosa onde pudemos utilizar vários recursos didáticos (sala de informática, laboratório, filme, debates e pesquisas). A grande maioria participou e desenvolveu as atividades propostas.

Parece que as dificuldades enfrentadas por Cintia e Magda não as impediram de realizar uma experiência nova e satisfatória.

Um outro fato que nos permite compreender como Malu conseguiu dar suporte a uma conduta que transpareceu firme e clara quanto aos seus propósitos, foi a intenção de explorar parte de sua nova experiência para elaborar sua dissertação de mestrado. Não havia conhecimento nem por parte do grupo de professores e nem minha, sobre as intenções de Malu nesse sentido. Isso talvez tenha evitado um possível movimento de resistência por parte do grupo. No entanto, em nenhum momento Malu me disse ter ocultado suas intenções com a finalidade de evitar tal efeito. Conscientemente ela admitiu ter se utilizado de "uma jogada" para conquistar a confiança dos professores e com isso conseguir adesão ao seu projeto e conseqüentemente obter os dados para sua pesquisa.

A gente já tinha essa intenção mas isso não estava explícito. Isso foi uma jogada para escolher, para aproximar do professor. Porque para o professor abrir sua sala de aula, mudar sua estrutura de aula, um mês 
aplicando um projeto, tinha que ter um compromisso aí.(...) Hoje eu vejo que se eu tivesse que repetir, eu tinha que ser mais firme para não comprometer minha pesquisa, porque o meu objetivo era outro.

No $2^{\circ}$. semestre do curso, a proposta para o grupo foi a elaboração de um módulo de ensino com escolha livre do tema, das séries para as quais seria aplicado, do número de aulas necessário, na condição de seguir a estrutura temaconteúdo-atividade. O planejamento do módulo se deu durante os encontros nos meses de agosto e setembro, acompanhado pela formadora, e a aplicação ficou reservada para os meses de outubro e novembro. Cíntia e Magda, estimuladas a elaborarem um outro projeto ainda que baseado no material de Malu, começaram a dar os primeiros passos na direção da autonomia, da dissociação do saber da formadora.

Magda: A parceria foi muito boa, tanto a Malu como a Andréa (uma estagiária que auxiliou as professoras) nos apoiaram muito. Pudemos reformular o projeto "Convivendo com as Calorias" baseado no projeto "Fármacos", o que para nós foi muito interessante e nos deu a possibilidade de recriar o que já trabalhávamos.

\section{Nem tudo funciona como se quer}

Em determinado momento de nossa entrevista, Malu mencionou um aspecto de sua prática que a incomodava, encarando-o como uma falha de sua conduta:

O que eu acho que falta é o retorno, né? O que ele aprendeu aqui? Com o quê ele sai a mais?Com o aluno a gente tem esse retorno, você tem avaliação, tem coisas escritas. E o professor? Como é que eu vou avaliar?

Malu relatou que toda sua formação inicial e continuada fora voltada para linhas não tradicionais de ensino. Lecionou em escolas públicas e particulares sempre privilegiando uma linha construtivista, adotando métodos, estratégias e materiais não convencionais. Criticava com veemência uma colega que havia apreendido os mesmos modelos que ela na universidade, mas que na prática defendia o ensino tradicional.

Eu não conseguia entender na minha cabeça como que o professor que busca um curso de formação que traz alguma coisa nova, de inovação, diferente de abordar em sala de aula, ele no grupo aceita aquilo, fala, trabalha e depois volta, chega lá, faz o tradicional. Igual eu tenho uma colega minha: não é a mesma pessoa que se formou comigo, não pode 
ser! Saímos da faculdade juntas, na mesma turma, formadas do mesmo jeito, trabalhamos com o mesmo material. Ela ia nos cursos, discutia, fazia tudo no curso. Quando ela teve oportunidade de ir para sala de aula, ela começou a dar aula com o material também, mas aí quando ela foi para uma outra escola, que escolhia o material, ela preferiu mil vezes o tradicional.

Sabemos que o ensino não tradicional não exclui processos de avaliação dos alunos e acreditamos que Malu também o sabia. Mas o que nos chama a atenção, é o fato de Malu não se sentir tão à vontade para avaliar o grupo de professores, quanto se sentia quando avaliava seus alunos do ensino médio. .

Igual eu cheguei a semana passada, eu falei: gente, mas eu tenho que cobrar alguma coisa, né? E quem vem aqui, senta e não faz nada? Não vai fazer nada? Igual a semana passada, eu cheguei e pedi para as duas [professoras Ilda e Bete] escreverem, cobrei alguma coisa formal. Para mim foi uma atitude assim: vou tomar uma decisão, porque eu vi que elas não se articulavam. Eu fui lá e falei: "então passem por escrito".

Ao contrário da postura descontraída e desarmada que Malu adotou em relação aos professores no início do curso, chegou um momento em que ela necessitou resgatar sua posição de Mestre. No entanto, tomar a decisão de assumir uma postura mais autoritária cobrando um maior envolvimento dessas professoras, como ela entendia ser o seu papel, não se mostrou uma tarefa fácil na prática.

Acompanhando o grupo na elaboração do módulo, Malu se preocupava quando percebia a dificuldade das professoras Ilda e Bete para se envolverem com o trabalho. Sobre isso ela reflete:

A gente pediu para eles planejarem o módulo de ensino. O que Ilda está fazendo não é módulo de ensino, o que Bete está fazendo não é módulo de ensino. E aí, como é que eu chego? Uma pessoa sozinha numa escola, cheia de dificuldades, vou apertar ela [Ilda] como? Não sei como é que eu faço isso! Me incomoda, sabe. Aí eu fico pensando se eu estou fazendo de conta para ela que eu estou criticando, que aquilo ali é o módulo de ensino. E se ela não entendeu que tinha que fazer um módulo de ensino? Ou se ela entendeu que tinha que planejar [só] mais uma atividade? Porque quando ela pôs no papel ali, eu falei para mim mesma: isso aqui não é módulo de ensino. Ela [Ilda] falou que já deu [aplicou o módulo] e que eles [os alunos] já vão apresentar [seus resultados] agora. 
Malu sentiu que a situação era delicada e confessou não saber como agir. A formadora tinha como pressuposto o respeito à liberdade individual dos professores, tanto no planejamento quanto na implementação dos seus projetos. Mas como diz Rosa (1996), sobre os desafios da mudança diante de uma perspectiva construtivista, não pode haver confusão, comum aos professores, entre manter um ambiente de liberdade de expressão e eximir-se de direção. Pensamos que esse comentário de Rosa vale para a situação da formadora em relação às professoras Ilda e Bete.

O que nos parece importante no conflito de Malu é comentar sobre a sua dificuldade em como exercer seu papel de formadora com a autoridade que Ihe é própria e necessária. Sobre esse papel Copello e Sanmartí (2001) colocam que o fato de se "afirmar que os professores, por si mesmos, devem reconhecer, avaliar e decidir não implica que se está diminuindo o papel da pessoa orientadora, já que ela tem a difícil e importante função de promover as atividades que possibilitem o reconhecimento, a avaliação e tomada de decisões".

É complicado. Você vai tratar ele [o professor] como um aluno?Vai chamar sua atenção? Eu tenho que chegar para o professor e falar assim: você não está cumprindo o combinado, ou, você não atingiu a meta. Não sei.

A dificuldade de Malu em ocupar e sustentar a posição de Mestre, talvez esteja associada ao fato dela não se enxergar como diferente na relação formadorprofessor. Para ela, a relação ainda ficava no nível professor-professor, o que tornava desconfortável uma ação de chegar no professor, chamar sua atenção, como ela colocou. Mesmo insegura, a formadora tentou uma saída possível, aproximando-se de Ilda no momento que julgou mais oportuno: quando Ilda comentou sobre sua dificuldade em ajudar um aluno que não conseguia compreender alguns conceitos químicos. No entanto, Malu não encontrou reciprocidade.

Eu falei: eu vou dar um texto sobre elemento químico para ela. Aí eu dei uma olhada no texto e falei: não vou dar. Aí ela falou do livro didático. Eu busquei [a solução] como se fosse interesse meu, fui buscar nos livros didáticos, ver o que cada um falava, mas ela não se interessou. Ela até 
foi lá, mas guardou os livros. É como se [ela pensasse]: "essa conversa não é comigo". Deixou nós duas ali discutindo e fez que não era com ela.

Eu participei com Malu desse episódio e lembro-me bem da postura de llda. Realmente, a professora não mostrou interesse em solucionar seu problema. Nos pareceu que Ilda não conseguia ajudar seu aluno porque também tinha dificuldades em compreender o conceito que tentava ensinar. Talvez, o constrangimento da professora em admitir sua própria dificuldade não lhe tenha permitido aceitar nossa ajuda. Psicanaliticamente, uma interpretação possível para a atitude de Ilda, decorre do fato de que sair de uma situação de conflito requer um saber sobre sua própria situação e um querer encontrar uma saída, que nem sempre é fácil. Pacca \& Villani (2000), ao discorrerem em um artigo sobre o conhecimento e o saber do professores de física, afirmam que quando um professor se queixa das aulas que ministra, mas não consegue mudar nada, revela que existe um saber mínimo sobre sua situação com um gozo que o amarra a uma repetição dolorosa. A professora Ilda nos parece ser o caso de quem se recusa saber, para que possa preservar a satisfação inconsciente de sua situação.

Mas para além da posição da professora llda, interessa-nos analisar a ação da formadora. Para Monteiro (1999), a autoridade é a diferença necessária à relação professor-aluno. Segundo a autora, a aprendizagem será realmente efetivada se o professor sustentar-se no lugar em que é colocado pelo aluno, ou seja, na posição de quem conhece o seu desejo, pelo menos até que se instaure a "transferência pedagógica" e inicie o processo de separação com a elaboração de um saber próprio e, de alguma forma, autônomo.

Apesar das dificuldades encontradas, Malu considerou que a experiência foi positiva para ela e para os professores que participaram do curso. Mais do que isso, percebeu que a maior parte do grupo estava avançando na perspectiva de elaborar seus próprios planejamentos, assim resolveu atender aos pedidos dos professores e dar continuidade ao trabalho de formação, apostando na expectativa de manter o grupo unido e crescendo. 


\section{Algumas Considerações}

A observação e análise da prática e das reflexões da formadora Malu revelaram-nos a existência de dois contrastes básicos. O primeiro deles mostra uma formadora insegura, em conflito, angustiada diante de situações novas para ela, naturalmente considerando a sua inexperiência no trato com professores. No entanto, esse mal-estar parece não afetar sua atuação, ao contrário, ela parece conduzir o curso de forma solta, leve e descontraída. Esse fato, que nos chamou a atenção, nos levou a indagar e a supor a existência de elementos, não evidentes, que estariam dando suporte à prática da formadora. Em nossa investigação foi possível trazer à tona alguns elementos ou fatores que, ao nosso olhar, estariam servindo-Ihe como apoio, ainda que de forma inconsciente para a formadora. Tais elementos, identificamos como sendo a confiança no seu material, a confiança advinda do seu orientador, o apoio da pesquisadora, as experiências positivas adquiridas ao longo se sua formação, a ausência de concepções prévias estereotipadas em relação ao grupo de professores, além do objetivo claro de explorar parte da nova experiência para elaborar sua dissertação.

O segundo contraste aparece quando ela revela, em suas reflexões, a necessidade clara de resgatar sua posição de mestre. No entanto, durante o ato de enfrentar uma situação que the exige uma postura mais firme, Malu acaba não conseguindo, apesar da tentativa, sustentar-se em sua posição de mestre. Também nesse caso supomos a existência de elementos, não evidentes, que pudessem explicar a ação da formadora na direção oposta de sua reflexão. Nossa hipótese é que a possível presença de um conflito, atuando sobre o papel da formadora e sua identidade como tal, não a permitia diferenciar-se do professor com o qual estava lidando, exercendo sobre ele a autoridade necessária.

Nossas conclusões a respeito de Malu apontam para a complexidade da situação: a relação entre a reflexão consciente da formadora e sua atuação na prática revela contrastes, nos mostrando que não necessariamente atuam na mesma direção. É o referencial psicanalítico que nos auxilia, nesse momento, a compreender, numa dimensão subjetiva, mais precisamente do inconsciente, os desvios entre a reflexão consciente e a ação da formadora. O jogo do inconsciente 
se mostra surpreendente, quando, ora atua a favor da situação, possibilitando à formadora uma condução leve e descontraída do curso, ora contra, dificultando a sustentação de seu papel de mestre.

Nesse sentido, acreditamos que um questionamento mais profundo da formadora a respeito das suas posições subjetivas, contando com a ajuda de um interlocutor apoiado no referencial teórico da Psicanálise, pode revelar-se eficaz na medida em que pode trazer à tona elementos inconscientes com os quais ela pode aprender a lidar. Com isso, apostamos na possibilidade dela conduzir melhor - com menos tensões e insatisfações - suas próximas tarefas de educar professores, sobretudo se resolver assumir uma proposta baseada na reflexão docente. 


\section{A EXPERIÊNCIA DO FORMADOR NIL}

A opção por investigar a posição subjetiva do formador no exercício do seu papel, veio se firmar via um processo que ocorreu em etapas, desde o amadurecimento dos conceitos da Psicanálise e suas possíveis articulações com a Educação. Primeiramente aposta numa aproximação, de uma forma análoga, entre os elementos da técnica analítica - a escuta especial, a atenção flutuante, a livre associação e intervenções adequadas - e o processo reflexivo dos professores em cursos de formação. Depois, a aposta num questionamento de natureza subjetiva das ações docentes, levando em conta a atuação do inconsciente. Finalmente, chegou-se à percepção do grau de importância do papel do formador, não apenas sua posição como orientador, mas pelo seu grau de envolvimento no processo de questionamento dos professores, visto que este, tal qual os professores que ele pretende formar, se mostra como um sujeito dividido, incompleto, submetido aos seus medos, desejos e contrastes.

Depois de um questionamento, não apenas das minhas práticas como as de Malu, mas, dos sujeitos por detrás dessas práticas, restou-me investigar outros sujeitos, outros formadores de professores, buscando neles a confirmação da hipótese de que suas posições subjetivas, não só interferem em suas ações, como nos resultados de suas práticas. Essa busca me levou até Nil.

\section{O saber como "o falo"}

Quando conheci Nil, por ocasião da minha pesquisa de mestrado, ele era professor em formação no programa Pró-Ciências ${ }^{6}$, no ano de 2000. À procura de sujeitos para minha pesquisa, Nil chamou-me a atenção pelo seu esforço e empenho para absorver todos os conhecimentos e oportunidades que o curso the

\footnotetext{
${ }^{6}$ O projeto Pró-Ciências, com o apoio financeiro da FAPESP, ocorreu entre os anos de 1999 e 2002, no Instituto de Química da Universidade de São Paulo. Teve como público alvo professores de Química do Ensino Médio e visava atender a demanda por parte das Diretorias de Ensino da Grande São Paulo, com o objetivo de aprofundar conceitos pedagógicos e químicos que resultassem em ações efetivas dos docentes na sala de aula. O grupo de formadores se encontrava ligado ao GEPEQ, Grupo de Pesquisa em Educação Química, também com sede no IQUSP.
} 
oferecia. Assim, vim a saber, na época, que Nil licenciou-se em Química e mantevese atuante como professor em escolas públicas num município da grande São Paulo durante pelo menos três anos. Começou profissionalmente na indústria metalúrgica, enquanto freqüentava o curso de Ciências de uma faculdade particular paulista. Apesar do pouco tempo na carreira docente e da formação tradicional que recebeu nos bancos escolares, despertou muito cedo para o compromisso de buscar formas alternativas de ensinar Química. Insatisfeito com os resultados da sua prática em sala de aula, procurou aperfeiçoamento em vários cursos de capacitação, dentre eles o Pró-Ciências.

Foi impressionante acompanhar o progresso profissional de Nil, tanto que acabei por reencontrá-lo no ano de 2005, cursando um programa de mestrado em Ensino de Ciências. Alguns dados que resgatei de sua história de vida, tornam para mim, ainda mais surpreendente sua evolução profissional e pessoal. Mesmo colhidos ainda na época da minha pesquisa de mestrado, vale a pena mencionálos, pois ainda mostram sua relevância quando tentamos compreender sua trajetória no meio acadêmico.

Para você ter uma idéia vou tentar explicar: eu sou o único na minha família que tem nível superior. Tenho pai e mãe analfabetos. A maioria dos meus parentes são analfabetos. Primos menores com grau de instrução quase nulo. Todos são migrantes nordestinos. Eu tenho que dar suporte para eles. Eu tenho que ficar correndo atrás de vaga: "olha, tem vaga em tal escola pra você estudar!”. Eu sei que estou ficando chato, mas se não faço isso o cara não progride. [grifo meu]

Nil parece assumir a responsabilidade não apenas pela sua educação, mas também pela educação de seus familiares. Sua origem e condição social humildes não se constituíram empecilhos para a mobilização de esforços na busca do saber. Isso que the possibilitou ascender a um lugar na sociedade, a única via pela qual conseguiu "ser alguém na vida". Enfim, para Nil, o saber assume a significação de falo. "O que é o falo? O que o sujeito busca para se completar, aquilo que ele acredita que necessita para ser inteiro" (Mrech, 2001, p.27). O falo, simbolicamente, estaria na origem de uma série de objetos que o sujeito irá buscar em sua vida, com a função de satisfazer o desejo de um gozo absoluto que, para Lacan, equivale ao mito do gozo incestuoso - como todo desejo, impossível de se satisfazer. 
Eu saí da indústria e apareceu uma oportunidade para o magistério. Fui lecionar. Fui tomando gosto pela coisa e me identifiquei. Tentar fazer com que uma pessoa adquira conhecimento é muito bom.(...) Eu tive um bom professor de química. Ele conseguiu aguçar a minha curiosidade. Ele me causou interesse e eu gostaria de estar fazendo isso com meus alunos. [grifo meu]

Parece que Nil elegeu o saber como um desses objetos, obtendo dele uma satisfação, mesmo que parcial e momentânea. A relação que Nil constrói com o conhecimento consegue levá-lo à superação de seus limites como professor, ao contrário do que ocorre com muitos docentes que se colocam em posição de desinteresse em relação a sua própria situação. No entanto, nem todos os seus alunos deverão estabelecer, como Nil, as mesmas relações identitárias com 0 conhecimento.

A razão que me fez inclui-lo novamente entre os meus sujeitos de pesquisa, advém do meu interesse em investigar a forma como Nil - um sujeito definitivamente marcado pela crença no saber acadêmico como meio de acesso a um lugar digno na sociedade - conduz seu papel de formador de professores. Especificamente, queremos observar que posições subjetivas ele ocupa diante da (a)diversidade das situações, diante dos outros (pequeno outro, igual e rival) e do(s) Outro(s), e quais as espécies de efeitos que essas posições resultaram. Logo, esperamos encontrar, a partir da análise de suas reflexões pessoais, os elementos que revelem o seu comprometimento com essas posições.

\section{Os conflitos iniciais}

Em sua constante busca pelo saber, os conhecimentos adquiridos ao longo dos cursos de capacitação, trouxeram elementos para Nil agregar novos desafios às suas propostas de ensino. Em seu mestrado, Nil amadurece a idéia de ensino contextualizado e propõe um curso intitulado "Contextualização e Ensino de Química" para os professores da rede estadual, junto a uma diretoria de ensino da grande São Paulo, com a finalidade de obter dados para sua dissertação. É importante salientar que Nil está pessoalmente convencido acerca do potencial do 
saber que ele traz da universidade, no qual ele se assenta, quando assume com entusiasmo sua novíssima condição de formador de professores.

Essa idéia do referencial da contextualização foi se mostrando para mim. Comecei a estudar, analisar e propor isso nas minhas aulas. Contextualizar o ensino não é ficar com exemplos. Contextualizar o ensino é muito bom, eu acho que isso é um dos diferenciais do ensino dentro da sala de aula. [grifo meu]

Para Nil, a prática de um ensino de Química descontextualizado, pouco significativo, onde o conhecimento fica reduzido à resolução de problemas imediatos, se tornou o mote para um estudo mais profundo das técnicas e metodologias de ensino.

Nil realizou seis encontros com seu grupo de professores, de quatro horas cada um, com um intervalo de mais ou menos dois meses entre um e outro, durante o ano de 2005. O primeiro, o segundo, o quinto e o sexto encontros, que aconteceram na diretoria de ensino, geraram material em vídeo para auxiliar nossas análises. O terceiro e o quarto encontros (somente este último registrado em vídeo) foram realizados na Universidade onde ocorreram também as três entrevistas com Nil ao longo desse período.

A proposta que Nil lançou ao seu grupo no primeiro encontro, teve início com a exposição clara dos seus objetivos: trazer subsídios teóricos que sustentam diferentes concepções de ensino contextualizado; conhecer a concepção prévia dos professores ouvindo seus relatos de experiências e aproximá-las das diferentes tendências dos referenciais teóricos; orientar o planejamento e aplicação em sala de aula uma atividade que contemple propostas de ensino contextualizado; discutir os resultados obtidos pelo grupo e finalmente, sugerir a elaboração de materiais para futuras publicações .

Importante dizer que, nesta proposta, está incluída a prática da reflexão docente. Não pretendemos aqui encontrar as concepções de Nil a respeito dessa prática, nem tampouco confrontá-las com as idéias de outros autores especialistas no assunto (lembremos que essa também não era a minha proposta ao trabalhar o tema linguagem com o meu grupo de professores). No caso, poderemos verificar 
em quais condições ela ocorreu, por meio do relato de Nil e das aulas gravadas em vídeo. Um exemplo disso, virá logo a seguir quando, na primeira entrevista, Nil fala das expectativas em relação ao grupo de professores participantes e das percepções e sentimentos diante dos resultados, logo após os primeiros encontros. Nil declara certa frustração ao perceber a dificuldade dos professores em realizar uma tarefa que considera simples dentro da sua proposta de curso: propor um tema gerador e, a partir dele, elencar alguns conceitos químicos a serem desenvolvidos.

\begin{abstract}
Minha expectativa era maior, não tanto no aspecto das idéias deles, isso eu ainda não consigo avaliar, é mais no entendimento de fazer as tarefas.(...) A forma que eles entregaram o material não foi clara. Eles não conseguiram entender isso e boa parte dos professores entregaram... de qualquer maneira.(...) Eu entendo que é um processo normal, de quem está trabalhando com a intervenção, com mudança de paradigma, de idéias que causam impacto. Eu não vou nem por essa idéia de má vontade, eu falo do não entendimento de como fazer atividade.Não pedimos para fazer muita coisa: um tema gerador, e alguns conteúdos químicos. Isso me deixou um pouco frustrado [grifo meu]
\end{abstract}

A dificuldade dos professores em fazer modificações na sua forma habitual de planejar, seguindo as orientações propostas pelo formador, não foi encarada por ele como má vontade do grupo ou função da novidade do desafio. Parece tratar-se de uma dificuldade de compreensão restrita ao campo cognitivo, intelectual.

Quando questionado sobre como os professores poderiam superar suas dificuldades frente à realização das tarefas, Nil sugere:

Através da reflexão, desses momentos juntos, de tentarem construir juntos, com a troca de idéias, refletir sobre o material produzido. É a reflexão em cima do material que eles vão produzir. [grifo meu]

O que o formador propõe para a superação das dificuldades nesse momento é que o professor faça uma reflexão sobre a sua ação, ação essa restrita à execução das tarefas, isto é, à manipulação dos saberes específicos veiculados pelo curso. Nil acredita que poderá ajudá-los, dando-Ihes o máximo de informações e fazendoos se questionarem a respeito de suas produções. 
Com elementos que já foram fornecidos no curso, informações, informações das idéias deles, das idéias dos acadêmicos sobre o tema. Acho que são elementos que podem ajudá-los e até mesmo a discussão depois, que eles vão fazer em cima. Acho que isso vai servir. Se não servisse também não tinha função de ter o curso!'[grifo meu]

A preocupação do formador é de que os professores compreendam e saibam executar as tarefas propostas pelo curso. A dificuldade cognitiva parece ser 0 obstáculo que impediria os professores de adotarem posturas diferenciadas em suas práticas docentes.

Se eles conseguirem trabalhar bem essas relações [tema e conteúdo], eles conseguem usar isso mais adiante, incorporar isso no seu trabalho. Se não conseguirem, com certeza vão continuar da mesma forma que já trabalhavam, conteúdo pelo conteúdo.[grifo meu]

A ênfase que demos nesta fala de Nil parece nos mostrar que o formador atrela o sucesso dos professores em conseguir realizar mudanças, em sua forma de planejar, ao bom desempenho na execução das tarefas propostas durante o curso. Em nossa visão, há que se questionar o desempenho apresentado pelos professores em cursos de capacitação e a adoção de mudanças efetivas na prática cotidiana, como relação pura de causa e efeito. Tal interpretação nos remete, por um momento, à pesquisa de Charlot que combate certas idéias oriundas da sociologia sobre as relações causais entre origem social dos estudantes franceses e fracasso escolar. Para o autor, o que se pode "constatar é que certos alunos fracassam nos aprendizados e pertencem a famílias populares. Nada mais. Falar em deficiência e atribuir esses fracassos à origem familiar não é dizer sua prática: é, sim , formular uma teoria” (Charlot, 2000, p.25). Charlot defende que o problema do fracasso escolar se encontra para além das teorias sociológicas e psicológicas e deve ser abordado pelo pesquisador em educação em termos da relação que o aluno, como sujeito singular, estabelece com o saber. Para defender sua teoria, Charlot recorre à Psicanálise e descobre em Lacan que o saber é da ordem do desejo.

Tendo em conta saber e desejo, e prosseguindo em nosso questionamento, nos parece ser necessário analisar em separado, sem, no entanto, negar a 
correlação entre os fatos, o desempenho apresentado pelos professores em cursos de capacitação e a adoção de mudanças efetivas na prática cotidiana. O primeiro fato, podemos considerá-lo ligado a um tipo de saber, que é o saber acadêmico. Certamente que esse saber envolve as habilidades cognitivas dos indivíduos, como já havia suposto Nil, quando percebeu a dificuldade dos professores "no entendimento de fazer as tarefas". O segundo termo, consideramo-lo ligado ao desejo, aquele que é a causa primeira da mobilização interna do sujeito em busca de sua satisfação. Ocorre que Nil, ao concluir que "se não conseguirem, com certeza vão continuar da mesma forma que já trabalhavam", certamente não está levando em conta o desejo dos seus professores.

A situação é complexa pois os professores podem apresentar bons desempenhos em cursos de capacitação, sem, no entanto, realizarem mudanças efetivas em suas práticas. Podem fazê-lo por estarem movidos por outros desejos, como agradar o Outro (o formador, o coordenador de sua escola) ou ainda para ganharem uma promoção de cargo. Do mesmo modo, a adoção de mudanças nas práticas docentes pode ocorrer à revelia do saber veiculado por determinado formador ou curso de capacitação e, muitas vezes, ocorre independente de formadores e cursos de capacitação.

Sobre essa discussão, nos ocorre agora um depoimento de Nil acerca de suas próprias dificuldades enquanto aluno em cursos de capacitação docente. Nil proferiu esta fala para o grupo de professores depois de ouvir as queixas dos mesmos sobre a situação atual das escolas da região:

A primeira vez em que eu sentei numa cadeira na Universidade de...., foi com uma professora do Telecurso 2000. Mas eu tomei uma "cacetada" dela, e eu passei três anos sem ir lá. Por quê? Porque tinha uma atividade que eu tinha que desenvolver alguma coisa sobre pilhas, mas era num grau tão alto, que eu encolhi na cadeira! Eu não sabia. E aí essa professora falou: "como vai trabalhar com o aluno se você não sabe isso?". Morri! .[grifo meu]

Deduzimos desta experiência de Nil, que seu desempenho como aprendiz não se mostrou nem um pouco satisfatório. Já concordamos anteriormente, "que uma das dificuldades dos professores em adotarem atividades inovadoras em suas 
práticas, esteja ligada à falta de domínio dos saberes conceituais e metodológicos de sua área". Talvez, na época, Nil não estivesse preparado para admitir que seus conhecimentos específicos fossem realmente falhos e o quanto isso poderia comprometer seu desempenho como professor, e principalmente aceitar que o véu que encobria suas deficiências fosse levantado de forma tão contundente. No entanto, esse momento de frustração, porém, não comprometeu seu desejo, pois apesar da situação, não desistiu de sua busca:

Depois eu fiquei um pouco chateado e não voltei mais. Mas aí eu continuava insatisfeito e resolvi voltar.

Não basta que o conhecimento seja significativo para o sujeito, num sentido apenas cognitivo. Nesse aspecto, a psicanálise faz a distinção entre conhecimento e saber. O saber tem um componente subjetivo, em boa parte inconsciente, que envolve gozo e desejo. Nos dizeres de Pacca \& Villani (2000), saber é parente de satisfação que insiste em ultrapassar o que se conhece.

O retorno de Nil para a universidade se deu na época do programa PróCiências, quando então, aparentemente, se sentiu convencido da proposta e acolhido pelos formadores.

Eu fui sincero e expus que eu tinha várias dificuldades, que os meus alunos questionavam as mesmas coisas. E aí eu fui convidado: "ah, vamos participar com a gente, vamos discutir esses assuntos".(...)

Dissemos aparentemente, porque não sabemos ao certo se a volta de Nil à universidade tenha se dado a partir da consciência de suas falhas conceituais, ou de ter encontrado um lugar onde suas deficiências pudessem ser encobertas. Talvez, ainda, Nil tenha permanecido nesse programa por ter encontrado um grupo que, em primeiro lugar, aceitou suas dificuldades e depois resolveu trabalhar com ele a partir delas. Considerando a história de Nil, acreditamos que a enunciação "você não sabe" a ele dirigida pela professora do Telecurso, tenha reforçado uma marca de sua infância e trazido de volta a ameaça de sua existência. Ou seja, "você não sabe" traz a marca de um significante que, para Lacan, sempre está ligado a outro, no caso, "você não é ninguém". 
Os entraves que impossibilitam o professor de realizar mudanças, sugerem, na psicanálise, questionamentos mais profundos. Mesmo admitindo os problemas da realidade concreta dos professores, os sujeitos podem assumir posturas diferentes em relação a eles, dependendo de suas modalidades de gozo. Para Lacan, a ignorância também é um tipo de saber e que tem a função de manter o sujeito em seu circuito de repetição. Sendo assim, o sujeito goza em sua ignorância, sem conseguir perceber isso ou pensar sobre isso.

O que os formadores não percebem é que não é suficiente fazer uma mediação cognitiva nos cursos de formação. Segundo Mrech (1999) esquece-se dos entraves no interior dos sujeitos em relação à própria construção do saber. Os professores precisam realizar uma passagem onde eles descubram que não basta querer para fazer. Eles podem querer mas não conseguir fazer, podem fazer sem querer, podem fazer sem saber que fazem.

Desde o primeiro encontro, Nil deixa clara a tarefa primordial dos professores: planejar e aplicar em sala de aula um módulo de ensino de acordo com o eixo teórico da contextualização e trazer para o grupo os resultados obtidos. Ao mesmo tempo, em suas reflexões, Nil fica em dúvida sobre a sua real efetivação.

Desde o primeiro dia, eu falei que tinham tarefas, e que no final iam produzir o material deles. Seria interessante que esse material eles aplicassem com os alunos, colhessem os resultados, e mandassem para os congressos também, participassem disso tudo, eu cheguei a comentar, falei isso com eles. (...) Os professores têm que estar participando de grupos de pesquisa, trocando idéias, trocando experiências, ouvindo as idéias que são colocadas pela academia, isso tem que ser constante. [grifo meu]

Apesar do esforço de Nil em manter os professores interessados e engajados numa proposta de mudança, em nossa interpretação, Nil tenta, inconscientemente, mobilizá-los a partir de seu próprio desejo, o desejo que o mobilizou a buscar o saber, ou seja, o reconhecimento dentro da sociedade e da academia. Ganhando o reconhecimento do Outro, Nil se fortalece e afasta o seu fantasma, isto é, a possibilidade de um retorno ao seu lugar de origem; um lugar sem destaque; um lugar onde ele "não é ninguém". 
Ocorre-me agora, que a escolha de Nil como sujeito da minha pesquisa, não residiu apenas nos motivos já expostos, mas também porque Nil, de certa forma, é o meu espelho. Sobre isso faço um parêntese. Recordemos que, ao iniciar a análise da minha experiência como formadora, ressaltei o significado acadêmico da minha pesquisa e a importância da posição que eu ocuparia, como uma forma do reconhecimento e da valorização das minhas capacidades profissionais. "Suponhamos que (uma criança) veja seu irmãozinho mamando no seio da mãe: é nessa imagem do outro que a criança então se localiza, reconhece seu próprio desejo. É por ela se identificar com esse outro que seu desejo aparece como desejo do outro. E, prontamente, ela quer estar no lugar dele" (Poulichet apud Nasio, 198, p.60). Pois bem, Nil é meu espelho porque me identifico com seu desejo.

Parece-me que ao escolher Nil como meu entrevistado, cuja história de vida já conhecia, de fato estava satisfazendo simultaneamente meu gozo e meu desejo. Minha identificação com o desejo de Nil me faz questionar sobre minha responsabilidade frente ao meu desejo. Enquanto Nil não me parece acomodado nem preguiçoso em relação ao seu desejo, correndo em busca de sua satisfação, ele percorre sua escalada profissional sem se deixar paralisar pelos obstáculos. Assim posso sentir-me culpada porque de forma mais passiva, me pego, muitas vezes, à espera de que o outro me tire do lugar, sem que eu empreenda esforços na superação das minhas dificuldades. Nil, como meu espelho, me apresenta minhas falhas, minha incompletude, e eu posso me satisfazer com isso. Entretanto, a identificação com o desejo de Nil também tem o efeito de desencadear a vontade de avançar no meu trabalho de tese, de superar as dificuldades encontradas, comungando com seu esforço.

\section{O caso do professor Milton}

As atividades propostas para os professores, além de se constituírem no eixo vital da programação do curso, funcionam também como uma medida de sua 
evolução. Nil sente que precisa analisar os materiais produzidos por eles para que possa intervir e orientar o grupo para novas atividades.

Nós temos mais dois encontros, o que vai decidir isso é o próximo encontro. Seria um sinalizador de como eles andam. Se dentro das tarefas que eles estiverem entregando a gente perceber as idéias deles, a gente tem que pensar em ações a serem tomadas. E aí a gente deve saber como proceder.

Vejamos como Nil descreve o conflito que enfrenta com o professor Milton que, segundo o formador, não estava se envolvendo com a proposta do curso.

o Milton apresentou o que ele desenvolve, interessante até, mas é o que ele já desenvolve, entende? Não precisa ser necessariamente diferente, desde que eles trabalhem com a idéia de contextualização e que eles apliquem, não precisa ser novo também. É que no caso do professor Milton, ele está mostrando uma experiência que ele teve e nada está indicando que ele vá trabalhar isso novamente. O objetivo é montar a unidade e aplicar.E depois de aplicado, de ter feito todo um trabalho, feito uma pesquisa, de relacionar conteúdos com o contexto, o contexto com conteúdo, a gente fazer uma discussão final, o que foi bom, o que não foi, dificuldades, aspectos positivos, fazer uma grande discussão no final sobre como foi esse processo.[grifo meu]

No entanto, quando questiono Nil sobre quais atitudes que ele pretende tomar em relação ao professor Milton, o formador não enxerga uma saída satisfatória. Ao invés disso, aponta algumas justificativas para a postura de Milton:

Você percebe no material dele que ele tem dificuldade para relacionar o contexto com a química. Ele cria umas barreiras para eu falar com ele. Se você analisar o material da gente, você vai perceber que sempre o movimento do professor Milton nas atividades é diferente dos outros. $E$ como fazer por fazer. É uma leitura minha. Fazer para não entrar na sala de aula, ter uma certificação. Eu acho que o professor Milton é aquele caso que ele está satisfeito. Ele sabe que está ruim, mas ele está satisfeito com isso que está lá e que ele não está muito a fim de mudar. $\boldsymbol{E}$ aí não tem jeito, eu acho que não tem jeito, não no meu curso.[grifo meu]

Nil tem dificuldades em assumir uma postura mais firme, mais incisiva em relação a Milton para descobrir quais as reais dificuldades dele e assim poder ajudá-lo. Seria o caso de verificar, por exemplo, se as dificuldades de Milton não 
estariam relacionadas ao próprio entendimento do conteúdo de química e, deste modo, emperrando o seu desenvolvimento no curso. O cuidado que se deve ter, no caso, é que quando se tomam certas posições, como destituir-se da sua função simbólica como mestre, simplesmente apostando na falta de interesse ou de desejo do outro, o resultado, como vimos, pode ser a paralisação de ambos, professor e formador.

O recuo de Nil frente ao professor Milton nos faz lembrar o recuo de Malu frente à professora Ilda, quando ambos os formadores "desistem" de seus aprendizes, pois não conseguem sustentar seus papéis de mestre. Encarnar o mestre também pressupõe saber sustentar a dificuldade do seu aprendiz.

Podemos fazer uma analogia interessante com o papel do analista em relação ao seu paciente. Lembro-me de um episódio relatado por minha analista quando atendia uma criança em seu consultório. Em certo momento da sessão, enquanto brincavam, a criança lhe disse que não queria mais comparecer às sessões. $A$ analista, percebendo o movimento inconsciente de resistência da criança ao trabalho de análise, concordou, sem questioná-la, em não recebê-la mais. $A$ criança, satisfeita, pediu à analista que retomassem as brincadeiras, ao que a analista atendeu prontamente. A analista poderia ceder ao seu desejo de analisá-la não participando mais das brincadeiras com ela naquela sessão, ou mandando-a embora. Ao invés disso, naquele momento, sustentou a recusa da criança. Ao final da sessão, a criança - percebendo a oposição entre a postura impositiva de sua mãe, que the obrigava a comparecer às sessões, e a surpreendente acolhida da analista, ao deixá-la à vontade - Ihe disse que havia "mudado de idéia" e que poderiam se encontrar na próxima semana.

A ausência de uma atitude de investigação por parte do formador em relação ao professor Milton vem no sentido contrário das reflexões de Nil, que declara querer saber sobre os impedimentos dos professores em adotar a idéia de contextualização em suas práticas:

Mas por que você não vai aplicar isso em sala de aula? Aí tem os entraves também. Eu quero verificar quais são esses entraves, porque só entender a idéia [dos professores a respeito de ensino contextualizado] 
não é interessante, tem que mostrar os entraves também, porque ele não trabalha dessa forma. [grifo meu]

O formador, como já exposto, acredita que oferecendo um conjunto de informações - que ele denomina de "subsídios para reflexão" - estaria contribuindo suficientemente para a promoção das mudanças de atitudes dos professores. Porém, há que se considerar que o desejo de saber do professor também está ligado a sua energia libidinal, atualmente em nível mínimo no caso dos professores. Isso pode explicar o caso do professor Milton que, a despeito de sua suposta dificuldade conceitual, parece também permanecer em estado de satisfação com o que já sabe, visto que, diante de um novo desafio, "o Milton apresentou o que ele já desenvolve".

O que podem fazer os formadores diante dessa situação? Como saber se posicionar diante das genuínas dificuldades dos professores em formação ou das suas resistências frente ao saber novo? Algumas falas de Nil dirigidas aos professores durante os encontros, demonstram uma tentativa de derrubar barreiras, pelo menos as de natureza prática, propondo algumas soluções alternativas. Diante das queixas dos professores sobre as condições precárias das escolas com relação à falta de material adequado e auxílio financeiro, Nil relata para eles como enfrentou as mesmas dificuldades enquanto professor:

As exigências vão surgindo, nós vamos procurando sanar as deficiências, tanto da xerox, eu entendo, a gente procura sanar. Por exemplo, eu fui trabalhar um texto sobre o conceito de dissociação iônica, de ionização, de acidez e basicidade. Esse texto eu passei na lousa. Depois que eu passei na lousa eu dei um monte de questões, passei também na lousa para que eles tenham uma discussão no segundo momento. Então eu também tenho dificuldade com isso, de xerox.

Apesar dos investimentos de Nil estarem dirigidos para o saber acadêmico dos professores, seu inconsciente sabe o quanto o desejo é responsável pela mobilização do professor, pois ele próprio pode dar testemunho. Educar, segundo Freud, se encontra entre as tarefas impossíveis, ao lado de governar e curar (psicanaliticamente). E muitos foram os sentidos atribuídos aos dizeres de Freud. Aqui, sustentamos a visão de Lopes (2005) de que, se educar é um ofício que se dá 
sobre a influência que um homem pode exercer sobre outro por meio da palavra, sua impossibilidade reside no fato de que não se submete o inconsciente - pois é ele que nos sujeita. Portanto, educar comporta dizer de um mal-estar permanente nessa tarefa. $O$ importante é que ao saber dos limites de sua atuação, um formador não paralise o seu trabalho.

\section{Os resultados obtidos foram os esperados?}

Na entrevista concedida após o penúltimo encontro com os professores, Nil trouxe alguns resultados parciais que conseguiu depois de analisar a produção do grupo. Nil parece mais satisfeito que no início do curso:

No sentido da reflexão sobre as idéias discutidas sobre contextualização, foi o melhor encontro, eu acho que foi. Eu acredito que foi o momento em que eles mais comentaram, mais disseram entender. De acordo com a discussão das idéias de contextualização e da análise desse material, eu vi que as idéias foram bem trabalhadas, foram bem entendidas pelos colegas- professores. Então, nesse sentido eu fiquei muito contente com o resultado.[grifo meu]

Embora, na visão de Nil, os professores tenham preenchido suas expectativas pelo menos em relação ao corpo conceitual da sua proposta, ainda lhe resta a angústia de perceber que parte do grupo não entende, da mesma forma que ele, o objetivo de um ensino contextualizado.

Ao trabalhar de forma contextualizada, a principal coisa é a aprendizagem, não é aumentar o interesse do aluno, não é motivar o aluno, isso é conseqüência, entendeu? $\boldsymbol{E}$ o professor coloca isso como objetivo. (...) E aí tenho uma dificuldade porque eu quero mostrar para eles, não a partir de uma percepção minha, mas a partir de estudos, de pesquisas, da própria universidade. Aí eu posso repetir que, contextualizar de forma adequada possibilita a aprendizagem.[grifo meu]

Nil tem o respaldo do saber da universidade diante daquilo que deseja ensinar aos seus professores. Ao praticar o discurso da Universidade - um dos quatro discursos (do Mestre, da Universidade, do Analista e da Histérica) que Lacan elabora para dizer sobre o enlaçamento do sujeito com a ordem social - o educador 
autoriza-se do autor, da bibliografia, para impor saber ao outro (o estudante) objetivado (tratado como objeto). No caso, Nil se compromete com o conhecimento didático-pedagógico - o ensino contextualizado - fazendo o possível para sustentálo também nos professores. Nil trabalha com a crença de que um saber produzido por uma comunidade científica trará resultados satisfatórios para os professores, desde que eles se disponham a aceitá-lo.

O discurso da Universidade, predominante e implícito na fala de Nil, é o mesmo discurso a que fora submetido em sua própria formação continuada. Para Villani \& Barolli (2005), o aluno que se submete a esse discurso se sentirá culpado por não se achar a altura da demanda do professor provocando, a exemplo de Nil, sua exclusão do processo, como ele mesmo relatou em sua experiência no Telecurso 2000. Nos parece que o discurso da Universidade seja eficiente na Educação somente quando o aprendiz está percebendo estar no caminho errado e precisa de um corte que o oriente numa nova direção.

Um outro efeito que esse discurso pode produzir no sujeito é levá-lo a uma conduta meramente burocrática em termos de aprendizagem, o que reforça a discussão anterior sobre o desempenho apresentado pelos professores em cursos de capacitação e a adoção de mudanças efetivas na prática cotidiana. Segundo Pereira (2005), de posse do discurso da Universidade, o educador "faz de seus estudantes objetos de sua imposição de saber, mas que só faz produzir um aluno subversivo, que não aceita a condição de ser puro objeto. Inventa outra coisa" (2005, p.108). No caso do professor Milton, segundo Nil, "se você analisar o material da gente, você vai perceber que sempre o movimento do professor Milton nas atividades é diferente dos outros".

Em nossa interpretação, parece que algo semelhante ocorre com outros professores no que se refere à realização de tarefas de forma burocrática. Quando analisamos a auto-avaliação do grupo, percebe-se que alguns professores emitem respostas padronizadas e pouco criativas quando se pretende saber "qual foi a mensagem mais importante que o formador conseguiu transmitir" durante o curso: 
Benedita: Trabalhar com o ensino contextualizado contribui para a formação de um aluno crítico.

Márcio: A importância e a maneira de relacionar os conceitos químicos ao cotidiano de nossos alunos.

Kátia: Utilizar a contextualização como recurso de ensino.

Essas respostas são indicativas, para nós, da produção de sujeitos alienados, no caso, no saber do formador, que é o saber da universidade. Para esses professores fica difícil modificar sua relação com o conhecimento, fazê-los criar a partir do pouco espaço deixado para o desejo.

Por outro lado, enquanto o discurso da Universidade aliena, o discurso da Histérica impulsiona o sujeito na direção do desejo de saber, mesmo que, inicialmente este desejo possa estar apoiado no saber didático-pedagógico em questão. Julgamos que Nil tenha, em alguns momentos, se utilizado desse discurso na medida em que, num dado momento do curso, se dirige aos professores como aquele que reconhece que o seu saber não é pleno e impele o outro a buscar.

Sobre a dificuldade em química, na época em que eu saí da faculdade, eu tinha essa dificuldade mesmo e ainda encontro algumas dificuldades nesse sentido. Tinha dificuldades de trabalhar, de fazer o assunto ficar interessante, eu tinha todas as dificuldades, não só em química. $\boldsymbol{E}$ aí eu fui buscar.[grifo meu]

O efeito deste discurso aparece pela forma como a professora Neusa enuncia sua auto-avaliação: "a mudança depende só de nós, mesmo que haja dificuldades, nós conseguiremos atingir nossos objetivos se desejarmos".

Para Villani \& Barolli (2005), fazer o discurso da histérica não é nada trivial pois muitas vezes os aprendizes não estão dispostos a serem questionados em sua segurança. No caso de Nil os professores tinham dificuldade em admitir estarem equivocados no desempenho de suas tarefas . Isso explica sua fala quando ele nos conta sobre o que sente ao lidar com professores:

Trabalhar com professores é muito difícil. (...) Fica mais difícil em alguns momentos ele aceitar que o conhecimento dele está um pouco equivocado. (...) Por isso que a minha preocupação nesse curso é não esbarrar nessas táticas de resistência.[grifo meu] 
Os depoimentos de alguns professores, expressos nas auto-avaliações às quais tivemos acesso, também podem ser indícios da superação das resistências e da intenção de uma procura para além de seus conhecimentos.

Geni: Para mim, que não tinha conhecimento deste tipo de abordagem didática, foi de grande aproveitamento. Aprendi muito. (...) Quando a gente se une e traça objetivos com vontade de alcançá-los, conseguimos vencer a maior parte dos obstáculos.

Igor: [O formador] fez com que nós entendêssemos várias coisas que não conseguíamos enxergar. (...) Ele conseguiu transmitir que eu, como pessoa e como profissional, sou capaz de desenvolver trabalhos, atividades e muito mais coisas para serem trabalhadas com meus alunos. [grifo meu]

A elevação da auto-estima no caso de alguns professores, pode ser também um outro efeito do esforço realizado na aprendizagem, com a conseqüente obtenção de resultados satisfatórios que estimulam os sujeitos a acreditarem em suas capacidades de produzir e buscar um saber melhor.

\section{Algumas considerações}

O saber escolar, em especial, o saber da universidade assume uma importância fundamental na vida pessoal e profissional de Nil. O conhecimento foi e continua sendo, para ele, a principal via de acesso a um lugar na sociedade. Reconhecemos em Nil um desejo de, por um lado, separar-se do outro semelhante (sua família), mas, que de outro, o leva a "colar-se" nos Outros (seus formadores, a Academia) que dão sentido a sua existência.

Entendemos que os significantes saber, universidade e academia, são tão marcantes para Nil quanto ele acredita que devam ser para os outros, seus familiares, alunos e professores. Ao proferir o discurso da Universidade, Nil espera

que seus aprendizes estabeleçam como ele, relações identitárias com o saber. É como se Nil quisesse que eles gozassem da mesma forma que ele, a partir dos mesmos objetos.

Agindo a partir de sua posição subjetiva, compreende-se que o sentimento de impotência do formador pode levá-lo a adotar posturas em dois extremos. Num 
deles, o formador se vê numa tentativa inútil de ter o controle da situação ao levantar questões do tipo "mas por que você não vai aplicar isso em sala de aula?". Sem perceber, o formador tende a forçar o professor a realizar um trabalho meramente burocrático, como provavelmente aconteceu com o professor Milton: "É como fazer por fazer.Fazer para não entrar na sala de aula, ter uma certificação".

Num outro extremo, o formador desiste da sustentação do processo do outro, que tem tempo próprio. Não se trata do formador se responsabilizar pelo professor, mas de responsabilizar-se pelo seu papel de mestre. Caso contrário, como afirmou Nil em relação ao professor Milton, "aí não tem jeito, eu acho que não tem jeito, não no meu curso".

Apesar da impossibilidade da satisfação plena de seu desejo no outro, Nil é a prova viva de que é possível mudar os rumos da situação, na medida em que mostra como a sua busca pessoal vem operando transformações na sua vida passou de aluno a formador de professores. Vimos a dificuldade e o constrangimento que Nil enfrentou no início do seu processo na Universidade quando passou "três anos sem ir lá" e no entanto, "como continuava insatisfeito, resolveu voltar".

É possível que os mesmos significantes que operam em Nil possam operar em outros professores. Sobre tal influência não há controle pois, de acordo com a psicanálise, o resultado das intervenções de um sujeito sobre o outro é imprevisível. Algo como declara o professor Igor em sua auto-avaliação a respeito do formador: "ele fez com que nós entendêssemos várias coisas que não conseguíamos enxergar".

Acreditamos que se Nil, como formador, pretende levar adiante sua intenção de descobrir os entraves dos professores na adoção de práticas inovadoras, será necessário questionar sobre suas posições subjetivas que subjazem a sua prática. Com isso, poderá criar situações menos frustrantes e mais satisfatórias para ele e seus aprendizes. 


\section{A EXPERIÊNCIA DO FORMADOR RONALDO}

Ronaldo é biólogo graduado por uma universidade pública, onde também concluiu seu mestrado em Biologia, desenvolvendo o tema ensino de genética. Atualmente cursa um doutorado em Educação. Seu envolvimento com a formação de professores teve início nos tempos do mestrado, quando formou um grupo com outros pós-graduandos para lecionar genética para professores da rede pública. A partir daí, foi convidado a participar de outros projetos, dando continuidade ao trabalho com formação continuada de professores. Ronaldo também dá aulas de biologia para alunos do Ensino Médio.

Ao contrário de mim, de Malu e de Nil, Ronaldo, apesar de muito jovem, acumula mais tempo de experiência no trabalho com formação de professores. Nossa intenção é, inicialmente, verificar que novidades as experiências de Ronaldo nos trazem em termos de sua posição subjetiva enquanto formador.

Quando entrevistei Ronaldo, nos víamos pela primeira vez. Naquela ocasião, Ronaldo não estava envolvido em nenhum trabalho voltado à formação de professores e por isso não tive a oportunidade de acompanhar sua prática. Mesmo assim, Ronaldo me pareceu muito à vontade para falar de suas experiências e não poupou palavras para expressar seus sentimentos em relação ao que vivenciou.

\section{O trabalho com professores: um circuito de prazeres e desprazeres}

Desde que se formou em biologia, Ronaldo começou a se envolver com cursos de formação de professores. Ele e seu grupo se empenhavam em montar cursos e abdicavam de suas férias para trabalhar com os professores. E havia satisfação nessa tarefa.

A gente formava grupos de estudo e montava esses cursos de férias para professores. Então era legal porque, de todos os lados, você lidava com o professor. 
A identificação de Ronaldo com os professores acontece devido a algo que ele acredita terem em comum: gostarem de dar aula. Esta afinidade faz a aproximação entre o formador e os professores e a possibilidade de fazer laço parece ser um momento bastante aguardado. Porém, o estabelecimento de laços, segundo Ronaldo, só acontece quando os professores compreendem a proposta do curso e a sua postura como formador. Só a partir daí é que o trabalho com o público se torna prazeroso.

Para mim é muito divertido trabalhar com esse público, que é um público que gosta de coisas muito parecidas com que eu gosto, de dar aula. Tem ainda aquela coisa de: todo mundo ali é apaixonado pelo que faz, até os que não gostam parece que começam a gostar.[grifo meu]

Ronaldo se desgasta no início dos cursos, quando tem que fazer com que os professores entrem numa sintonia de trabalho. Isso ocorre quando Ronaldo tem que se confrontar com as expectativas dos professores, nem sempre de acordo com as suas. Depois disso, o curso entra numa fase mais produtiva.

Eles [os professores] esperam as respostas e um curso não vai dar isso. Até você tirar esse foco do curso e dirigir para uma outra coisa, vai um curso. Aí acabou, vem uma outra turma. Aí quando você estabelece os laços, consegue fazer isso, pronto [o curso acaba]. [grifo meu]

No entanto, depois de algumas experiências, o formador declara ter ficado um pouco enjoado e cansado de enfrentar situações que se repetem com a chegada de novas turmas.

Eu acho que eu cansei, porque chega uma hora que você vê que as reclamações são as mesmas, as angústias são as mesmas, assim como em qualquer turma, parece que você tem que começar de novo. Até pela falta de continuidade desses cursos... acabava falando: "agora vou começar tudo de novo". Então cansa um pouco, sabe, quando você forma uma turma, pronto, ela vai embora. (...) A gente não agüenta mais começar tudo do zero. [grifo meu]

O conflito de Ronaldo aparece na fala: parece que você tem que começar de novo. Ronaldo reclama da postura queixosa dos professores:

Dar um curso para esses professores é muito desgastante. Você tem que falar: "olha, eu não vou te dar respostas, não adianta ser mal educado". 
(...) Ele [o professor] chegava e começava a reclamar, reclamar, reclamar: "minha escola é uma droga, eu vim aqui porque vocês têm as respostas para tudo, o salário é baixo, o país vai mal...”. Criavam polêmica e depois, no final da primeira aula, saía todo mundo [professores e formadores] desanimado. (...)..[grifo meu]

Apesar do desgaste, ele nos conta que sempre acaba aceitando os convites que Ihe fazem para trabalhar em novas propostas. Em Ronaldo existe algo que insiste em se repetir: a dor de ter que "começar de novo" e, ao mesmo tempo, a satisfação obtida durante sua tarefa e na sua relação com seus aprendizes, nos parecem apontar para um ciclo de prazer e desprazer contínuos. Esse jogo nos parece extremamente interessante desvelar, pois nos indaga sobre quais elementos, em nossa hipótese, inconscientes, mantêm Ronaldo nesse circuito de repetição.

Para tentar uma saída desse circuito, Ronaldo procurou planejar cursos diferentes, mas convidando o mesmo público. Assim, Ronaldo conseguiria trabalhar em permanente estado de satisfação, sem precisar enfrentar o desprazer de "começar de novo".

Então a gente pode chamar só os interessados, ou seja, aqueles que já passaram por essa fase daquilo que a gente fala "sessão testemunhas", que é quando eles querem contar os problemas deles, porque isso também era um espaço importante. Mas não dá para todo curso você só ouvir reclamação e não produzir nada, né? Então, quando a gente conseguiu fazer um curso onde o professor sempre aparecia em vários cursos, a gente via que trabalhar era muito mais gratificante, muito mais eficiente..[grifo meu]

A partir do depoimento de Ronaldo, acreditamos ter encontrado outros elementos que poderiam trazê-lo para os novos desafios. No início, Ronaldo e seus colegas discutiam os conteúdos e as estratégias dos cursos de formação, sob a orientação de um professor. Depois, Ronaldo já podia contar com o apoio desse professor nos momentos que precisasse, sem a necessidade de sua presença constante. Ao mesmo tempo, esse professor confiava nele, deixando-o criar à vontade. Sua atual orientadora também apóia Ronaldo em sua trajetória como formador. 
Tinha um orientador, alguém que nos autorizava a criar, fazer o que a gente quisesse. (...) E ele, por uma série de motivos, não estava sempre com o nosso grupo. Então a gente agendava: "olha, você precisa dia tal fazer uma palestra sobre isso, tudo bem?" Ele: "tudo bem”. Mas todo o curso era montado por essa equipe. (...) Por exemplo, "T. do $S$ ”, foi um projeto que ela [sua orientadora] estava organizando na parte de ciências. Então ela falou: "Pessoal, é isso que eu gostaria que vocês fizessem, tudo bem?". Aí a gente começou a trabalhar, a gente mostrava para ela o que estava fazendo e aí foi meio nesse esquema de confiança: “você é capaz de fazer isso, por isso que você foi chamado, então um bom trabalho".[grifo meu]

Parece que os convites que Ronaldo recebia para trabalhar em cursos de formação reforçavam sua auto-confiança. Cada trabalho Ihe dava a oportunidade de construir sua autonomia enquanto formador. Graças aos incentivos que recebia, ficava fácil aceitá-los.

Acreditamos que o incentivo dos colegas e do coordenador dos cursos, a valorização das suas competências advindas da sua orientadora, o ganho de autonomia, além de poder estar próximo daqueles que têm a mesma paixão que a sua, sejam os elementos que estivessem sustentando e alimentando o gozo de Ronaldo, levando-o a permanecer no circuito de repetição. A tensão que tem que enfrentar a cada início de um novo curso - enquanto houver as queixas dos professores, a produção ao nível mínimo e a sintonia com a proposta do formador não for satisfatória - só dará lugar ao prazer perto do final do curso, quando as metas de Ronaldo forem alcançadas.

Inspirando-nos na obra A Erótica do Tempo de Jacques-Alain Miller (2000), uma maneira de visualizarmos o circuito de gozo de Ronaldo é considerar uma superfície euclidiana onde possamos projetá-lo. O percurso de Ronaldo nesse espaço pode ser representado, como veremos, de acordo com a oscilação de sua satisfação consciente: 


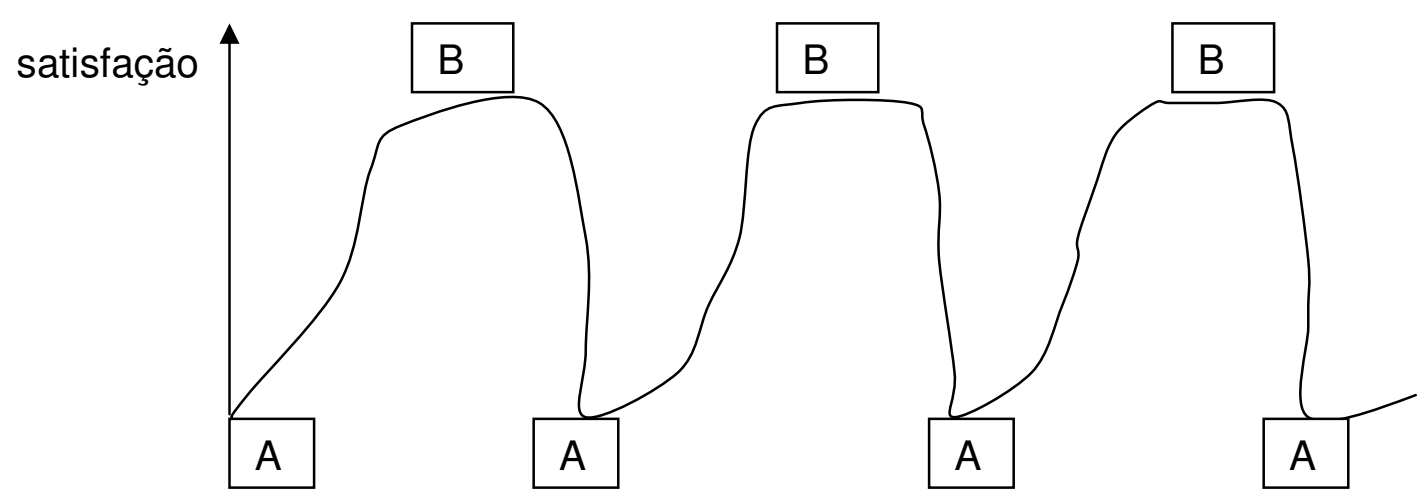

O ponto A corresponde ao início do curso, quando a satisfação de Ronaldo está ausente diante dos obstáculos que tem que transpor junto aos professores, enfrentando suas queixas e angústias. Durante o curso, existe todo um esforço do formador para mudar a freqüência, a sintonia do grupo e levá-los para uma produção mais satisfatória. A satisfação de Ronaldo aumenta conforme ele consegue elevar a produção do grupo. O pico de sua satisfação corresponde ao ponto B, quando o grupo se torna operante, de acordo com a proposta do curso. Nesse momento parece haver sintonia entre o formador e o grupo de professores; o trabalho se torna gratificante, eficiente. A satisfação do formador perdura por um breve momento, quando acontece um corte e o curso termina. Ronaldo retorna ao ponto A para começar tudo de novo.

Nos trechos de ascensão das curvas projetadas, Ronaldo caminha rumo ao seu objetivo como formador, o objetivo de formar um professor comprometido com sua tarefa, crítico diante da sua prática. Parece-nos que o movimento oscilatório de Ronaldo seja mantido pela esperança de que, da próxima vez, poderá ser diferente. Ao mesmo tempo, existe uma ilusão de lidar com professores livres de angústias, interessados, operantes, sintonizados com sua proposta de trabalho, ou seja, o professor ideal.

\section{A construção de um curso para professores}

Planejar um curso para professores, segundo Ronaldo e seu grupo, envolvia muito esforço e muitas variáveis eram analisadas: estruturar um eixo teórico e 
prático que contemplasse temas que supostamente seriam de interesse dos professores; atender a disponibilidade de horário dos professores; reunir um número de formadores suficiente para o acompanhamento do curso; disponibilizar recursos financeiros; convidar um pop star, um profissional de renome para dar "credibilidade ao curso"; elaborar atividades variadas; preparar um acervo contendo vídeos e textos - inclusive tradução de materiais estrangeiros - para utilizar durante o curso e para os professores levarem para casa. Porém os resultados da prática nem sempre correspondiam aos esperados.

E aí a gente tinha uma idéia que era : o professor devia, depois de um tempo, relatar a alguma coisa que ele fez em sala de aula, baseado naquilo que a gente discutiu. Então o curso acabava em junho e ele voltava em setembro para contar para a gente o que aconteceu. E acabava sendo uma coisa meio... sentimental demais, todo mundo com saudade, todo mundo gostou do que fez, mas o senso crítico ali, não dava para exigir muito, era mais uma comemoração, igual defesa de mestrado. É quase uma celebração do curso, vêm todos os professores e eles trazem os papéis, fotos e aí você fala: "nossa, tem uma série de coisas equivocadas que a gente já conversou, mas aqui não é mais o momento para isso". [grifo meu]

Pelo relato de Ronaldo, uma espécie de frustração é gerada ao final do curso, como se a expectativa do formador não ficasse preenchida. Mas, observar os resultados obtidos e planejar mudanças de estratégia para cursos posteriores, também fazia parte da busca por melhores resultados.

Os professores avaliavam o curso a cada semana e aí uma pessoa lia tudo isso e numa reunião prévia discutia isso com a gente: "olha, os professores estão falando isso, estão falando aquilo". Nem sempre isso era possivel, mas a gente trabalhava para isso, para discutir com eles durante o curso. E isso parece que ajudou bastante porque eles percebiam que estavam sendo ouvidos, apesar do curso ter um cronograma montado, eles falavam: "espera aí, eles estão acompanhando o que a gente está fazendo, não é um curso independente do professor". Era um curso que, dependendo da resposta deles, a gente iria comentar na aula seguinte. Tipo: "vocês estão conversando, vocês estão atrapalhando", questão de horários, algumas coisas organizacionais, a gente começou a discutir isso porque isso começou a aparecer como um problema para grupo. Então, tudo isso a gente mostrava para eles, que não era uma decisão só nossa, que era uma decisão deles também, que a gente precisava resolver isso. [grifo meu] 
Mesmo durante o curso, havia abertura para mudanças que partiam da avaliação dos professores. Ouvir esses professores e partilhar com eles as dificuldades do grupo, pelo menos aquelas ligadas à organização dos trabalhos, parecia importante para Ronaldo e seu grupo. No entanto, Ronaldo deixava claro os limites dessa escuta, pois não admitia ouvir as queixas do professor em relação à situação da escola, às políticas educacionais, salariais e outras dessa natureza que, para o formador, não tinham lugar num curso de formação continuada.

Então a gente não deixava dominar esse clima de que: "olha, tá tudo errado". A gente já tirava logo isso deles. Agora, salário baixo, a gente pode resolver isso no curso? Não. Então a gente vai discutir sobre salário aqui? Não. E eu ainda tinha uma postura que era assim: "vocês têm que discutir sobre salário baixo, só que não num espaço que não permite isso. Tem sindicato, tem representação, tem que saber os espaços que vocês podem fazer uma coisa ou outra. Aqui, infelizmente, a única coisa que eu posso te ajudar é discutir metodologia e conteúdo. Se o pai do seu aluno bebe, se o aluno é violento, se... eu infelizmente não sou competente o suficiente para te ajudar. Agora, só consigo te ajudar no que eu sou competente". [grifo meu]

Se a postura de Ronaldo é reveladora de um Mestre-Não-Todo, isto é, aquele que não detém todo saber sobre o professor, talvez não seja apenas porque as lamentações dos professores não tenham lugar num curso de formação, mas possa denotar uma falta de habilidade para lidar com questões de natureza mais subjetiva.

Por um lado, quando Ronaldo restringe seu trabalho apenas às questões de sua competência pedagógica, o formador tenta tirar os professores de seus circuitos de gozo e levá-los a um patamar mais produtivo. Por outro, a dificuldade de Ronaldo em lidar com certos problemas trazidos pelos professores é uma dificuldade em encarar o professor real, aquele que está distante do ideal imaginado, com o qual, o formador, como já discutimos, carrega a ilusão de lidar.

Recordemos que, ao analisar a experiência do professor Nil, dissemos que encarnar o mestre também pressupõe saber sustentar a dificuldade do seu aprendiz. Isso não significa que o formador se deixe envolver ou assuma para si o problema do outro. Mas significa que, mesmo participando do problema, consiga tomar dele a distância necessária e abrir espaço para que o outro assuma a responsabilidade pelo seu problema. Esta é uma posição fundamental para os 
formadores: saber lidar com as demandas dos professores. Mas parece que, para Ronaldo, assumir essa posição ainda o deixa numa situação desconfortável.

Eu tive que me policiar muito para não ficar aquela visão de que: "olha, eu sei , eu sou lá da universidade e vocês não são". Você nunca faz isso de propósito, mas às vezes uma frase escapa e bate no ego deles. Eu sei que eu pensei muito: o que eu vou falar, pensava três vezes antes. Eu não conseguia ficar conformado: "ah, tá horrível a apresentação daquele grupo e eu vou falar que está boa?”. Então eu chegava lá e falava: "olha, isso tá bom mas... tem que tomar cuidado com isso, com isso"... E aí foi legal, porque assim, aprendi que as relações é que ficam. Se eu não conseguir construir uma relação com a pessoa, ela não vai me ouvir. Posso ser da Universidade, qualquer lugar, ela não vai me ouvir. Então comecei a me preocupar muito com isso nesses cursos, em estabelecer um vínculo com essas pessoas. E aí mostrar que eu estava lá para ajudá-los, não estava lá para provar nada para eles. [grifo meu]

Em sua reflexão, Ronaldo reconhece que está numa outra posição, diferente e superior dos seus professores. No caso, o saber acadêmico faz a diferença, e, exatamente isso o coloca na posição de mestre, o Sujeito Suposto Saber. É necessário que o formador a reconheça e a assuma. Por mais que ele tente negar ou ocultar isso diante dos professores, pensando "três vezes antes" de falar, fica clara a interferência do plano inconsciente, pois, como ele mesmo disse, "às vezes uma frase escapa".

Ronaldo vem percebendo a importância das relações interpessoais no processo de formação do professor e do papel do formador na construção dessas relações. Quando Ronaldo diz que "se não conseguir construir uma relação com a pessoa, ela não vai me ouvir", significa dizer, analogamente a uma situação de análise, que se o analista, "com todo o seu comportamento - a maneira como faz o paciente entrar, como fala com ele, as palavras que usa para fazer suas intervenções, a duração destas, o tom de sua voz - não souber fazer surgir a autoridade, aparecer o grande Outro, o referente, o interlocutor dos novos sintomas que vão aparecer e que vão trazer a significação transferencial”, não haverá condição para análise e o paciente desiste. Embora o paciente que chega para consultar esse analista já traga em si uma pré-transferência, o analista precisa 
ocupar esse lugar, o lugar de alguém que está ali para ouvir, para escutar.(Nasio,1999, p.46-49).

Embora tenhamos usado a analogia do papel do analista para falar do papel do formador e de suas posições em relação às demandas do analisando e do professor, respectivamente, tenhamos claro também que cada qual, analista e professor, lida com demandas diferentes. Cada qual, analista e professor, deve assumir responsabilidade pela demanda que lhe é enviada, o primeiro, pela demanda de cura; o segundo, pela demanda de saber. Para responder à demanda de cura, o analista também deve demandar ao paciente. Responsabilizar-se pela demanda não significa satisfazer a demanda do outro, mas implicar-se com sua demanda ao outro, mesmo "tendo que suportar não tê-las respondidas". Por exemplo, segundo Forbes, Nasio apontou para ele três demandas do analista: a propaganda da psicanálise, o reconhecimento como analista e o pagamento das sessões (Forbes, 1999,VII). Através de sua demanda, o analista expressa o seu desejo, que é o de ocupar o lugar de objeto imaginário causa do desejo do analisando.

No caso do formador, este deve responsabilizar-se pelo seu desejo de ensinar. Apesar do desconforto de assumir essa posição, Ronaldo expressa claramente sua demanda aos professores, por exemplo, quando limita seu espaço de atuação "tem sindicato, tem representação, tem que saber os espaços que vocês podem fazer uma coisa ou outra. Aqui, infelizmente, a única coisa que eu posso te ajudar é discutir metodologia e conteúdo"- e consegue mostrar que não cede ao seu desejo de ensinar quando se diz inconformado com o desempenho insatisfatório de seus professores, chamando-Ihes a atenção, porém, com delicadeza. Lembremos, bem ao contrário, das posições assumidas por Malu e Nil diante de situações semelhantes com os professores Ilda e Milton.

Parece-nos que o vínculo formador-professor que Ronaldo procura estabelecer, passa pela ocultação das diferenças. No seu imaginário, talvez fosse essa uma atitude necessária para ganhar a atenção e a confiança do grupo. Se, por um lado, Ronaldo não quer parecer "superior" aos professores, também não quer parecer "inferior": 
Mas eu estava no começo do mestrado, não usava barba. Você imagina chegar na aula: "oi pessoal, sou eu que vou dar um curso!"

Nesta fala, Ronaldo nos dá mais uma mostra de que, até no corpo ele também precisa ocultar as diferenças, transformar sua aparência pueril numa figura mais parecida com a de seus alunos-professores. Para Lacan, o corpo, na psicanálise pode ser contemplado de três pontos de vista, sendo um deles o simbólico. O corpo simbólico representa um conjunto de elementos significantes, capazes de falar ao outro de seu sentido. O significante barba pode dizer ao outro sobre o sentido de uma autoridade ou de um poder em Ronaldo, assim como na história bíblica que conhecemos, a força física estaria associada aos cabelos de Sansão.

Este detalhe em Ronaldo me faz lembrar o início da minha carreira docente, aos dezenove anos. A diretora de uma escola pública havia me convidado para dar aulas de matemática, para uma turma de alunos da $3^{\mathrm{a}}$. série do Ensino Médio, do período noturno. Em sua maioria, os alunos eram mais velhos do que eu. Até hoje me lembro de suas palavras de boas-vindas, soando em tom de alerta: "Mas tome cuidado, se você não se impuser, eles [os alunos] vão 'montar' em você!". Tratei logo de transformar a figura original de uma jovem franzina, com vestes despojadas e sorriso natural, numa adulta se apresentando com saias quase longas, sandálias de salto "10" e cenho cerrado. Assim como Ronaldo, imaginei que pudesse ocultar as nossas diferenças de idade, fazendo modificações na imagem do meu corpo. Mas ao contrário de Ronaldo - cuja atitude o levou a descobrir, mais tarde, a importância e o prazer das relações interpessoais no processo educativo - a escolha por essa posição me levou a um afastamento dos alunos, no sentido afetivo e físico. Nas minhas aulas, não havia espaço para brincadeiras ou descontração; passei anos a fio lecionando no pequeno espaço entre o quadro negro e a mesa do professor. No meu imaginário, ser adulto era sinônimo de ser sério e só assim poderia conquistar o respeito do outro.

O que Ronaldo e eu não percebemos, é que não é criando marcas na imagem do corpo, tais como barba ou saias longas, conseguiríamos conquistar a autoridade 
necessária, mas lidando com a posição subjetiva que nós ocupamos no imaginário dos aprendizes. O significante formador ou educador já se encontra instalado, socialmente construído na psique dos alunos e nós precisamos saber como ocupar esse lugar. A princípio, o formador é o sujeito suposto saber, aquele que tem a solução pronta para todos os problemas. Com o tempo, o formador ou educador, deverá se descolar dessa imagem e desiludir os aprendizes nesse sentido, sem porém, abandoná-los. Assumir-se incompleto diante deles, impulsiona e abre espaço para eles buscarem seus próprios caminhos, suas próprias soluções. A seu modo, Ronaldo faz diversas colocações com esse sentido:

Geralmente o problema [que os professores trazem para o formador] é do salário, problema do aluno, problema da escola, nunca é da sua prática. Eu nem acho que o problema é só deles, mas é também deles. Então a gente mostrava a ele e falava: "Então agora se vira para tentar resolver. Eu não sei resolver o seu problema. É o seu aluno, na sua escola, o que eu posso te falar? Você quer metodologia, tem aqui um monte, toma. Agora, se vai funcionar você é que tem que saber e não eu, você é que tem que resolver isso". [grifo meu]

A diferença necessária que Ronaldo precisa resgatar em relação aos seus professores é justamente aquela que os fará produzir. O saber do Mestre é a diferença que precisa ficar explícita para os professores, como algo que eles não possuem. No entanto, um cuidado se faz necessário segundo Pacca \& Villani (2000), pois se o professor se apresenta como aquele que sabe tudo, ocupará todo o espaço do aluno e, ao contrário, se o professor se apresenta inseguro, quem ocupará todo o espaço será o aluno. Em nenhum dos casos o saber do aluno será modificado.

\section{Algumas considerações}

Queremos pontuar dois aspectos da entrevista de Ronaldo, que nos chamaram a atenção. O primeiro é o fato do formador girar em seu ciclo de repetição, denunciando um gozo para o qual tenta uma saída ilusória. Isto é, Ronaldo enfrenta 
repetidamente a situação angustiante de um início de curso, com professores despreparados, queixosos e fora de sintonia com sua proposta. Depois, descarrega sua tensão no prazer de fazê-los agir produtivamente. A saída ilusória está em criar cursos diferentes contando com o público de cursos anteriores, na tentativa evitar contato com as angústias trazidas pelas novas turmas.

Ronaldo também dá aulas de biologia para o ensino médio. A cada ano precisa começar tudo de novo com as novas turmas. Mas Ronaldo não tem queixas em relação a esses seus alunos, como as que ele apresenta quando se trata de iniciar um curso para professores. Isso pode ser explicado mais uma vez, pela dificuldade em assumir a posição de mestre diante de um grupo de adultos, com o qual prefere manter uma relação de exclusão de suas diferenças. Talvez Ronaldo encontre mais facilidade em "bancar" o mestre diante dos mais jovens, onde as diferenças são mais explícitas e a posição do mestre fica melhor caracterizada.

Daí o outro aspecto da posição subjetiva de Ronaldo. Lidar com as novas turmas exige que ele assuma sua autoridade de mestre no saber. Admitir sua superioridade diante dos professores o deixa em situação desconfortável. Desperta no formador uma espécie de sentimento de culpa. As atitudes de tentar ocultar essa diferença, policiando-se para não mostrar que "está por cima", não dizendo aos professores "olha, eu sei, eu sou lá da universidade e vocês não são", ou que "está por baixo", aparecendo para dar um curso sem a barba, talvez seja a forma que Ronaldo encontrou para lidar melhor com o sentimento de culpa.

A análise da experiência de Ronaldo, não apenas trouxe mais elementos para pensar na posição subjetiva do formador, mas possibilitou marcar alguma diferença entre a posição de formadores novatos, como eu, Malu e Nil, e a de um formador mais experiente. A partir dos dados que analisamos, destacamos um aspecto da posição de Ronaldo, que representa, em nossa interpretação, um avanço para o papel do formador. Ronaldo percebe a importância das relações interpessoais estabelecidas entre ele e os professores. A partir dessas relações, o formador consegue ser ouvido pelos professores, se posicionar em termos dos seus limites de atuação e ouvi-los a partir desses. Com isso, ganha a confiança do grupo e coloca os professores em atitude de trabalho. 


\section{A EXPERIÊNCIA DA FORMADORA JERUSA}

Até o momento, a análise das experiências dos formadores novatos, permitiunos chegar a algumas conclusões sobre as interferências do plano inconsciente no posicionamento subjetivo desses docentes e conseqüentemente, nos resultados obtidos em suas práticas. Mas, a análise das reflexões de um formador um pouco mais experiente como Ronaldo, nos revelou algumas novidades em relação a essas posições que, como dissemos, representam algum avanço no papel do formador.

Embora esta pesquisa não pretendesse, em suas intenções primeiras, investigar comparativamente as experiências de formadores novatos e experientes, acreditamos que, a partir da análise dos dados de Ronaldo, se possa encontrar novidades interessantes na experiência de formadores de longa carreira e, aparentemente, bem sucedidos em seus papéis. Por isso, resolvemos buscar um outro formador com esse perfil e encontramos Jerusa.

Jerusa é uma professora de física que possui longa experiência na formação inicial e continuada de professores. Atua numa universidade do Estado e atualmente mantém um grupo de onze professores da rede pública, sete deles juntos há quatro anos, em formação continuada. Um grande número de suas publicações na área de formação de professores de física, discute desde propostas de abordagem didático-pedagógica para a educação de professores, até resultados de experiências que têm acumulado ao longo de sua carreira como docente e pesquisadora.

Seu trabalho de formação de professores, de acordo com seus artigos publicados, está todo comprometido com a proposta reflexiva de D. Schön, K. Zeichner, A. Nóvoa, P. Perrenoud e outros autores nessa linha. Jerusa associa a essa proposta, saberes do referencial teórico da psicanálise, buscando em $\mathrm{J}$. Lacan, J.A. Miller e em outros autores que conectam esses saberes à Educação, como L. Lajonquière e L. Mrech, uma perspectiva de formação que leva em conta a dimensão subjetiva dos professores, atuando sobre os resultados de suas práticas. 
Não tive a oportunidade de acompanhar a prática de Jerusa, de modo que nossas análises versarão apenas sobre os relatos da prática da formadora, obtidos por meio de entrevista.

\section{A formadora sabe o que quer}

Em entrevista, quando Jerusa se refere à sua experiência como formadora, nos impressionam a segurança e a crença firme que ela deposita em suas concepções.

Você precisa assistir o meu curso! Você vai ver! O meu curso, eu acho que é aquele [onde acontece uma prática] efetivo! [grifo meu]

Pelo tom exaltado dessa declaração, Jerusa demonstra acreditar fortemente na efetividade dos resultados de seus cursos, quando analisa as práticas dos professores que passam por eles. Ela sente que os grupos, em geral, se envolvem seriamente com os desafios propostos; da mesma maneira, the parecem correspondidos em suas expectativas.

Eles se engajam no projeto, eles gostam. Nós trabalhamos aqui todas as quartas-feiras das 2 às 8 da noite. Eles ficam até às 8 e, às vezes, até passam. [grifo meu]

Também nos chamou a atenção o alto grau de satisfação que the proporciona a prática docente.

Realmente você abre um mundo para eles [os professores], que eu acho que é muito gratificante, para eles e para o formador também. Eu sou entusiasmada com meu grupo! [grifo meu]

O que pretendemos investigar, a partir dos relatos sobre a prática de Jerusa, são quais elementos dão sustentação ao seu alto grau de satisfação, assim como o do seu grupo de professores. Não se trata de tentar descobrir uma "fórmula de sucesso", e sim, de acordo com nossa proposta inicial, revelar as posições subjetivas assumidas pela formadora e fazer possíveis conexões com os resultados que ela obtém. Evidentemente, não podemos negar a aprendizagem e o aperfeiçoamento que houve nas práticas da formadora, em função do tempo de 
vivência ao lado de professores em formação continuada e inicial e também de suas atividades como pesquisadora. Nesse sentido, Jerusa tem consciência de que possui um conjunto de atribuições e ingredientes que julga essenciais para sua função:

O formador também tem uma coisa que eu acho muito importante, ele tem que ter muita experiência da disciplina, ele tem que ter um acervo importante de experimentos, de situações específicas da fenomenologia. Ele tem que saber o seu conteúdo.

Entretanto, apesar de acreditar possuir os ingredientes favoráveis ao seu trabalho, cremos existirem outros elementos que o sustentam e que, em nossa hipótese, ultrapassam os conhecimentos acumulados durante anos de experiência. O que leva a formadora a obter resultados satisfatórios em seus cursos, além do que ela própria sabe dizer sobre eles?

Jerusa tem um propósito sólido e transmite com segurança seus objetivos para o grupo de professores. Faz questão de deixar claras as condições e os compromissos que serão assumidos por parte da formadora e dos professores durante o curso.

Eu não vou para o curso sem nenhum objetivo, sem nenhuma questão, sem nenhum plano.A gente tem uma proposta inicial.(...) Nós trabalhamos aqui todas as quartas-feiras das 2 às 8 da noite. (...) Condição: todos estão com uma turma, pelo menos, onde eles vão ensinar eletricidade. E isso daí é obrigatório, esse é o compromisso deles. Eles têm que dar aula daquilo. (...) Então eu vou trabalhar com eles paralelamente à sala de aula. Eu vou construir com eles ou eles vão construir comigo.(...) Tem momentos que eu digo: "agora o tema é falar sobre essa questão, todos vão falar sobre essa questão, cinco minutos para cada um”. Eu não deixo ninguém ficar quietinho muito tempo não, e sempre dou uma questão que todo mundo vai falar. [grifo meu]

Jerusa nos conta que os professores trabalham e se dedicam muito ao curso e essa é uma conquista que não é apenas mérito do grupo, ou questão de sorte, mas é fruto de um trabalho consciente da formadora:

Pode ser, eu tive sorte, mas eu acho que os procedimentos que eu adotei construíram isso. 
Apesar de não estar envolvida diretamente com o cotidiano das escolas de ensino médio, Jerusa demonstra que tem sensibilidade e que conhece bem o universo profissional do seu grupo, por meio do relato dos professores:

Os problemas, que são variadíssimos, de todas as naturezas possíveis, desde o problema com a direção da escola, com os pais, com a dificuldade de dar aula, porque tem visita ao Playcenter, tem o teatro, tem a bandeira para hastear numa determinada data, tem festa na escola... então tem todas as coisas, todas essas dificuldades, além do problema mais dele ali na sala de aula, o problema de indisciplina dos alunos, a violência que está dentro da sala de aula, problema da desgraça dos alunos mesmo. Você vê adolescentes com drogas, com álcool, com problemas familiares. Então o professor procura espaço, porque na escola ele não tem as reuniões de professores, eu vejo, eles mesmos dizem, os professores vão lá levar receita de bolo, fazer crochê, nas horas atividade. Então quantos deles têm essa situação na escola!

Embora haja um planejamento prévio para o curso, Jerusa abre espaço para outras demandas dos professores:

Então, um lugar onde eles possam se reunir e conversar daqueles problemas que os afligem, isso passa a ser atraente para alguns professores. E mais ainda, se eles tiverem nesse espaço a possibilidade de discutir mesmo as suas aulas.(...) Mas é uma proposta inicial que ela te dá uma abertura para muitas coisas e para muitos problemas aparecerem.

Jerusa parte do princípio de que a demanda dos professores, relativa aos problemas reais que eles enfrentam na sala de aula, é o ponto de partida para as muitas discussões e reflexões.

Se você não trabalhar com problemas que sejam próprios do professor, autenticamente gerados por ele, é difícil fazer uma transposição para sala de aula daquilo que ele está vendo no curso de formação continuada. (...) Porque a coisa mais importante é você levar a situações de discussão, de interação, de reflexão. E quando você vai interagir, discutir, refletir? Quando o assunto é seu. Se ele não for seu, gerado por uma necessidade sua, por que você vai refletir sobre aquilo? Não tem polêmica, não tem discussão, não tem conflito.

A proposta de Jerusa vai ao encontro de um dos elementos básicos da teoria de Schön, que é a reflexão a partir do conhecimento prático do professor. Jerusa acredita que o papel do formador, "é propiciar o espaço para identificação de problemas, propiciar espaço para reflexão sobre as questões, para aprofundamento 
das questões". Nessa linha, cabe ao formador utilizar estratégias que encaminhem os professores para um questionamento da sua prática. Jerusa faz isso lançando, nos momentos adequados, perguntas ao professor, conseguindo provocar uma certa desestabilização em seu saber.

A primeira tarefa que eu dou para eles: fazer o seu planejamento para ensinar eletricidade para os seus alunos na escola. O primeiro planejamento que eles fazem é o índice de um livro, geralmente. "O que você quer com esse item? $O$ que você quer que aconteça quando você vai falar sobre esse item?" Ele vai me dar uma resposta: "eu quero que os alunos aprendam isso". "Como é que você vai saber que eles aprenderam? E se eles já sabem sobre isso? Você perguntou se eles já sabem? O que eles já sabem?" Então você já cria algumas dúvidas.

Apesar da grande experiência, Jerusa admite que essa não é uma tarefa fácil pois "é muito mais fácil você levar uma aula pronta e você passar". Um resultado observável da ação persistente da formadora pode ser demonstrado pelo relato:

Sempre você questionar a ação dele: o que é que ele fez, o que é que ele propôs, como é que ele saiu de uma enrascada. Então você tem que canalizar um pouco essa competência que ele tem de se virar, no outro sentido. Então eles começam a ficar, por exemplo, muito pesquisadores. Eles vão olhar um livro e dizem: "esse livro não está correto; essa palavra que ele está usando aqui não é boa, é isso que está dando confusão". Sabe, eles começam a ser críticos em cima das coisas. Eles vão procurar leituras.

Outro elemento que compõe o eixo da teoria de Schön, que é um pouco mais evidenciado em Zeichner, é a reflexão que leva em conta os problemas institucionais que permeiam e afetam o cotidiano do professor. Quando os professores levam à formadora, problemas dessa natureza, Jerusa também consegue discutir e propor iniciativas para lidar com essas questões. Jerusa relata um exemplo dessa situação:

Nesse começo de semestre, uma (das professoras) ficou abaladíssima porque a aula dela, que era às quintas-feiras, eles passaram para sextafeira, nas duas últimas aulas, e os alunos já foram embora. Então qual é a solução? Depois de uma choradeira, conversa e tal, a gente chegou à conclusão: ela vai continuar com os que estiverem. Se tiver meia dúzia, ela vai dar aula para meia dúzia. Porque é outra coisa que você mexe 
com o professor. Por que, qual é o esquema da escola? O professor diz: "só tem dez alunos, eu não vou dar aula" e a diretora diz: "isso mesmo, só dez,[o restante] vai ficar defasado". E ela foi e pegou o negócio e está continuando, assim mais tranqüila. Mas era o problema dela. Era um problema da sala de aula. Como levar para sala de aula se ele não tem sala de aula? Então eu acho que os pesquisadores perdem isso, o sonho é que eles levem para sala de aula, é fazer a transposição para a aula, todo mundo quer e não sabe fazer.

Parece que Jerusa conseguiu uma "receita" que funciona, um modo particular de conduzir o curso, com características próprias. Desenvolveu uma escuta dos professores que constitui a conduta básica do seu curso. Ao mesmo tempo, the permite obter satisfação no que faz:.

\begin{abstract}
Porque eu levo essa idéia de que todos têm o que dizer. Eu acho que isso é uma chave importante no processo, você abrir espaço para o outro se manifestar. (...) É interessante e eu me divirto! Para mim é sempre uma novidade, porque se você vai para ouvir o que o outro está dizendo, você nunca sabe o que é, mesmo sendo em cima de uma tarefa que você pôs, tem uma variedade grande de interpretações, de formas de relato e eles me surpreendem. (..) Eu acho muito saboroso mesmo, essa coisa de você ouvir as novidades. Eu acho que está por trás a minha crença mesmo de que na cabeça dos professores têm coisas incríveis a respeito do ser professor e você tem que abrir para isso aparecer.
\end{abstract}

A postura assumida por Jerusa transmite ao grupo a confiança necessária para que haja uma interação proveitosa entre a formadora e os professores. A posição de escuta da formadora permite ao professor que ele fale e se exponha.

O primeiro contato é meio constrangedor, mas depois todo mundo quer falar, é incrivel: " agora sou eu, deixa eu contar”. (...) Eles vão então, cada vez tendo mais o que falar, mais vontade de falar.(...) Eu gosto muito de ouvir, gosto muito de ouvir, mais do que falar. Eu acho que isso é uma coisa que eu sinto como positiva para mim. Então eles falam, eles falam tudo, falam tudo.[grifo meu]

Além de permitir que os professores falem, Jerusa acha importante que eles estabeleçam uma escuta do próprio discurso e do discurso dos colegas. Essa é uma estratégia que funciona para manter o grupo unido e envolvido na discussão do momento, evitando as dispersões e o desinteresse diante das falas muito particulares. 
Às vezes, em alguns momentos, eu digo: "olha, fulano disse isso. Isso fez sentido?" Você pergunta para o outro: "o que você acha? Fulano está dizendo isso, como é que você vê essa coisa?" Eu faço muito isso dentro do grupo. Essa coisa de fazer os próprios professores pensarem nos conteúdos que eles trouxeram, nas coisas que eles disseram. Eu acho que isso é uma coisa boa, tomar consciência do que você está dizendo, o que aquilo significa.

Em nenhum momento Jerusa faz menção ou sente necessidade de adotar qualquer mecanismo formal de controle sobre o grupo:

Esse ano eu diminuí o meu tempo de participação no grupo, ao invés de ficar das 2 até às 8 , eu estou ficando agora menos da metade do tempo. $O$ resto do tempo eles ficam sozinhos trabalhando. (...) Ficam mesmo, muitas vezes passando das 8 , porque eles ficam com um problemão que foi gerado ali, com questões. Às vezes eu deixo alguma tarefa específica, um experimento.

O modo consciente de trabalho com os professores, que vai desde a existência de um planejamento inicial, os compromissos e condições pré-estabelecidas com o grupo, o questionamento constante, até a posição de escuta da formadora, somado à experiência de Jerusa, não nos parece suficiente para explicar o comportamento e os resultados satisfatórios obtidos com o grupo.

Os laços de comprometimento ao nível interpessoal e profissional que se estabeleceram entre o grupo e a formadora e entre os próprios membros do grupo, nos sugere algo além do que se passa na dimensão consciente dos sujeitos e que não se captura tão facilmente.

No caso da formadora, para a qual dirigimos o foco de nossa análise, a questão pode ser interpretada com a ajuda do referencial psicanalítico. Primeiramente, Jerusa mantém o grupo sob o seu controle, trabalhando de acordo com suas exigências e no entanto parece não realizar esforços em tal empreendimento: "eu não vou na sala de aula, eu não faço nenhuma vistoria, não faço nenhuma observação". Jerusa encarna, para os professores, o papel de grande Outro, aquele para o qual inconscientemente os professores prestam contas de suas ações. Para Lacan, o Outro é internalizado, um parceiro com o qual o sujeito interage sem perceber. O Outro representa a lei, o simbólico, e por isso faz sua captura por meio da palavra, da linguagem. 
Para que Jerusa ocupe o lugar do Outro no imaginário dos professores, ela precisa operar com o discurso do Mestre, seduzindo o outro pela palavra e determinando assim a maneira pela qual as coisas devem funcionar. É um discurso típico que produz laços (Villani \& Barolli, 2005), tais como os laços de comprometimento entre as propostas da formadora e as tarefas dos professores. Nos parece que a segurança de Jerusa constitui um antídoto ao clima de desânimo que domina a escola brasileira no Ensino Médio. Quando as atividades de formação de Jerusa iniciaram, os discursos dominantes eram queixas- lamento pela situação do ensino público (e também particular). Atualmente não parece haver mais espaço para essas queixas, sendo substituídas por questionamentos mais objetivos em torno de problemas também objetivos.

Em segundo lugar, Jerusa representa para os professores o Sujeito Suposto Saber, aquele que faz semblante de saber sobre o outro, aquele que supostamente irá trazer as respostas que os professores esperam. $O$ que os professores não percebem é que o Outro também é incompleto.

Em terceiro lugar, como conseqüência dos anteriores, Jerusa consegue estabelecer com os professores uma transferência de trabalho, um efeito que desperta nos professores um desejo de saber para além do imediatismo das soluções mágicas, das "receitas" prontas.

Agora, às vezes, tem alguns que descobrem outras coisas e depende muito do programa de aperfeiçoamento, ou de atualização, ou de formação continuada. Eles descobrem outras coisas, outros prazeres, outras motivações. Eu falo isso porque é o que eu vejo com o grupo com que eu trabalho. Então aquela coisa dele perceber o que é bom para ele, o que faz bem para ele. [grifo meu]

A postura de interrogar as certezas dos professores, instigando-os a produzir um saber melhor, é uma característica de um outro discurso utilizado pela formadora, o discurso da Histérica. O efeito que se produz nos professores que se submetem a esse discurso é de uma espécie de satisfação em perceber a incompletude do seu conhecimento (Villani \& Barolli, 2005). Isso se revela, por 
exemplo, no prazer dos professores em permanecerem envolvidos várias horas com uma questão proposta pela formadora.

Entendemos que Jerusa funciona como espelho para o professor que, por sua vez, transfere para sua prática uma postura semelhante à da formadora. $O$ professor não leva para a sala de aula apenas os conteúdos de física ou metodologias novas que aprendeu, mas uma forma de se posicionar na docência, tal qual ele percebeu na formadora.

Isso aí não é na segunda aula nem na terceira aula, mas eles estão construindo e eles vão entendendo, vão começando a escutar os alunos, então eles mexem com a interação em sala de aula.(...) E você imagina então depois deles estarem dando aula e começarem a entrar nessa condição de estar ouvindo o que o aluno diz, começar a prestar atenção no que o seu aluno diz, para você começar a orientar sua aula. (...) São eles mesmos que dão [as oficinas], os mais antigos, que já trabalharam aqui. É muito interessante você ver como eles dão as oficinas, como eles repetem, como eles transpõem o procedimento: deixando os professores trabalharem, dando atenção às coisas que eles expressam, conversando com todos, aí você vê o comportamento deles.

Jerusa mostra o quanto se surpreende com os resultados trazidos pelos professores além do que era esperado:

A maior parte das vezes eu peço para eles escreverem. Eles concluíram já que escrever é muito importante. Então eles começam a pedir para os alunos também, eles começaram a perceber que na hora de escrever aparecem as coisas. (...) Tenho uma professora que disse: "incrivel, eu fiz uma avaliação e concluí que os meus alunos aprenderam mais do que eu esperava". Quer dizer, ela também prestou atenção para o que veio a mais, para o que ela não tinha cobrado. Eu achei isso uma informação preciosa. "Vocês também me surpreendem", eu disse para ela, "nessas coisas que vocês fazem, como isso que você está me dizendo". [grifo meu]

A transferência de trabalho permitiu que os professores evoluíssem de sua situação inicial na qual predominava a busca pelo saber do formador, para uma situação onde o professor passa a elaborar e operar com seu próprio saber.

Eles acabam fazendo uns planejamentos muito originais, muito bons mesmo, com competência. Eles começam a fazer coisa com coisa, não querem mais saber do planejamento pronto. Eles não querem porque 
isso não faz mais sentido. (...) Então você vê assim, essas coisas, de ume de outro, esses comentários que você percebe que o professor já está mais exigente.

Exemplos assim mostram que os professores ultrapassaram o patamar da aprendizagem significativa para o da aprendizagem satisfatória (Villani et al., 2004). $\mathrm{Na}$ experiência da aprendizagem satisfatória, o aprendiz atinge a satisfação (goza) em saber além de suas necessidades, envolvendo-se em tarefas que ultrapassam a dimensão do significado cognitivo e do sentido afetivo.

Conscientemente ou não, Jerusa se torna um modelo implícito para os professores, na medida em que, muitas vezes, os resultados de suas ações ultrapassam suas intenções.

\section{Algumas considerações}

O relato da formadora Jerusa apresenta uma seqüência progressivamente reveladora sobre as características do seu trabalho e permite aprofundar bastante 0 sentido da reflexão, que ela usa como forma de aprimoramento didático dos professores.

Toda a primeira parte da entrevista, nos revela uma formadora consciente do seu plano de trabalho, autora de sua metodologia. Enfim, seu sucesso com os professores tem, como uma das atividades-chave, conseguir, primeiramente, deslocar o professor da situação de esperar por uma receita que resolva seus problemas, para uma análise do que acontece em sua sala de aula. Jerusa faz isso pelo menos há quinze anos e efetivamente aprendeu a fazê-lo com competência. Mas o faz porque ela própria se autoriza a fazê-lo, a partir de sua posição simbólica de mestre.

Ela prefere manter sempre o mesmo grupo, introduzindo aos poucos outros membros, na medida do possível e das disponibilidades. Os professores raramente desistem do curso e até professores que freqüentaram cursos anteriores, candidatam-se a voltar. É singular o caso de uma professora que participou do curso há quase quinze anos e atualmente, a cada semana, percorre quinhentos 
quilômetros de ônibus para participar do encontro com o grupo. No curso anterior, tinha aprendido a refletir sobre sua atividade com muito proveito, realizando até uma pesquisa sobre isso. É difícil entender que alguém que tenha mais de vinte e cinco anos de profissão, se disponha a enfrentar um longo trajeto de ônibus e as complicações de uma cidade como São Paulo, somente porque a atividade traz razoáveis benefícios à docência.

Então, parece possível concluir que a reflexão sobre sua própria atividade didática é uma condição necessária, mas não suficiente para explicar o envolvimento dos professores com a atividade de aperfeiçoamento.

Para nos ajudar a compreender esse fato, Jerusa acrescenta um novo ingrediente: problemas antes considerados insolúveis - como o caso da professora que teve suas aulas passadas para as sextas-feiras - são enfrentados: a reflexão em conjunto oferece um espectro de soluções mais amplo e portanto aumenta as chances de conseguir soluções. Se a sala de aula muitas vezes é dolorosa e frustrante, nada mais restaurador do que um grupo no qual é gostoso trabalhar. Este clima fica evidente quando a formadora recheia seu discurso com palavras como incrível, saboroso, prazer, gosto, gratificante, divirto, entusiasmada, surpreendem. Elas parecem apontar para um condimento que torna a reflexão efetivamente diferenciada. Parece que os professores ultrapassaram o patamar da aprendizagem significativa para o da aprendizagem satisfatória, ou seja, a relação com o apreender e ensinar não é regulada simplesmente por aquilo que faz sentido, que se encaixa racionalmente, mas por aquilo que gera satisfação, que amarra e que envolve.

A especificidade deste grupo e deste curso é que o que traz razoáveis benefícios à atividade didática também gera profunda satisfação. Então, a pergunta: o que conseguiu marcar e continua amarrando o grupo? Pode ser a relação da formadora com sua atividade de ensinar: ela gosta, se diverte, se satisfaz, enfim, é entusiasmada com sua atividade no grupo. Isso não é fruto da novidade, porque faz muito tempo que ministra esse tipo de curso. Ela consegue encontrar surpresas continuamente e consegue transmitir isso para seus professores. Por isso a 
satisfação que os amarra parece ter uma dimensão mais profunda, da ordem do desejo, da sublimação, uma maneira de tampar a falta inconsciente (Kupfer, 2000).

Percebe-se também que a formadora, sem nenhum propósito, conduz seu curso utilizando-se de elementos análogos aos da técnica analítica, os mesmos que eu pretendia levar a cabo na minha experiência como formadora. Jerusa tem uma escuta especial dos professores, desprovida de pré-julgamentos ou interesses particulares; os professores podem falar livremente, sem restrições quanto à natureza dos seus problemas e faz intervenções que questionam profundamente sua prática. A diferença, é que propomos um questionamento não apenas das práticas dos sujeitos, mas dos sujeitos das práticas, ou seja, de suas posições subjetivas frente ao mundo à sua volta, ao outro e a si mesmo, com a intenção de que esses sujeitos enfrentem com maior consciência as dificuldades de sua atividade docente.

Ao reler a entrevista, percebi que, rapidamente, fui colocada na mesma situação na qual, provavelmente, se encontram os professores quando entram em contato com o curso de Jerusa: fiquei encantada, perdendo quase completamente minha capacidade crítica e, talvez, sonhando um dia poder ter o mesmo sucesso. Assim, perdi também a ocasião de vislumbrar onde se encontrariam as angústias e os medos que Jerusa não revelou em sua fala, preferindo focalizar os aspectos bem sucedidos de sua atividade docente.

Atualmente, me pergunto por que ela não veio ao encontro de meu desejo de desvelar o mundo subjetivo do formador e não me facilitou a tarefa oferecendo pistas, por exemplo, sobre como ela enfrenta o problema de renovar sua prática docente, de forma a obter novas satisfações? Por que não falou de como lida com os desencontros inevitáveis? Por que não acenou aos riscos que não quer enfrentar? Por que não falou daquilo que ela ainda não consegue entender?

Interessante só notar agora, que, durante a análise desse caso, não me ocorreu, diferentemente dos outros formadores, momentos de identificação com Jerusa, nos quais poderia aparecer citando exemplos da minha atividade docente. Talvez isso possa ser explicado, revelando, mais uma vez, a minha posição subjetiva diante do outro: diante de alguém que mostra, e tem reconhecida, toda 
uma prática bem sucedida; diante do seu tempo de experiência nessa atividade; diante do saber que ela construiu e divulgou nos seus trabalhos de pesquisa; na verdade, o lugar que certamente Jerusa estaria ocupando para mim, fosse o lugar do grande Outro, da autoridade e da lei, e não o lugar do pequeno outro, com quem poderia me igualar e rivalizar.

Talvez isso também explique o fato de eu não ter insistido em acompanhar os encontros que ela estava realizando com seu grupo, na época em que me concedeu a entrevista. Talvez eu ainda não estivesse preparada para questionar o saber desse Outro, preferindo, inconscientemente, permanecer submetida a uma imagem idealizada da formadora.

Por sua vez, também não senti em Jerusa, o desejo de que eu acompanhasse o seu curso, embora houvesse um convite implícito em sua fala "Você precisa assistir o meu curso!". Talvez, a segurança de seu modus operandi - por meio do qual conseguiu um equilíbrio estável em sua atividade - oculte por detrás uma espécie de defesa inconsciente, contra algo que não conseguimos detectar. Entretanto, talvez teria sido proveitoso para ela, enfrentar esse tipo de reflexão. De qualquer forma, minha atuação certamente não foi estimulante nessa direção. 


\title{
CONSIDERAÇÕES FINAIS
}

\author{
Uma aluna ouviu um dia uma aula sobre Complexo \\ de Édipo e conseguiu depois disso mudar sua \\ conduta com a filha, fazendo desaparecer um \\ sintoma. Pode-se pensar que o conhecimento alterou \\ sua posição subjetiva? É melhor pensar que já havia \\ nela uma disposição prévia, que aguardava apenas \\ uma nomeação do que devia ser feito - a chuva caiu \\ em terreno fértil. (Kupfer,2000)
}

Quando nos propusemos a investigar a posição subjetiva do formador na condução do processo reflexivo de professores, procurávamos demarcar o lugar desse sujeito frente ao mundo que o rodeia, frente ao outro e frente a si mesmo. Mas o risco que se tentou evitar numa investigação desse tipo, era o de ficar apenas no campo das teorias que analisam o comportamento dos sujeitos, baseando-se na superfície do ego (consciente), do sujeito que só existe se for pensante. O sujeito que nos interessou aqui, não foi esse de Descartes, foi o da psicanálise, aquele sujeito que encontramos "na lembrança apagada, no significante que falta, no vazio de representação em que se manifesta o desejo" (Quinet,2000, p.13).

Entretanto, também não nos propusemos a fazer um trabalho de análise com nossos sujeitos de pesquisa, nem tampouco propor que eles façam isso com seus aprendizes - pois esta tarefa restrita está ao setting analítico e aos cuidados de um especialista - mas fazer uma aproximação dentro do que nos foi possível - e acreditamos ser possível - utilizando elementos do referencial teórico de Freud e 
Lacan. Por isso, não nos iludimos em pensar que tenhamos atingido esse sujeito, pois reconhecemos nossos limites como educadores não especialistas.

Contudo, é com enorme satisfação e consciência da responsabilidade, que nos arriscamos nesse campo, porque acreditamos que temos algo para dizer a todos aqueles que se interessam em compreender e lidar melhor com os problemas da educação e dos seus principais agentes: os docentes e os alunos.

Isto não significa que a psicanálise pode dar conta das soluções que procuramos. Até mesmo Freud, em suas incursões teóricas pela Educação, chegou a questionar a validade da aplicação da Psicanálise, concluindo, ao final, que a Educação é uma profissão impossível. Porém, "impossível não é sinônimo de irrealizável, mas indica principalmente a idéia de algo que não pode ser jamais integralmente alcançado: o domínio, a direção e o controle que estão na base de qualquer sistema pedagógico" (Kupfer, 2001,p.59). A transmissão dessa noção aos educadores, para nós, já representa um grande avanço.

Millot (1987), que discutiu profundamente as relações entre Psicanálise e Educação, em seu livro Freud Antipedagogo, é uma psicanalista da atualidade que representa a posição de uma Psicanálise que não pode, de modo algum, casar-se com a Educação. Millot diz isso se referindo à missão profilática que a Educação teria, no esforço de evitar a produção do recalque e a algumas tentativas fracassadas nesse sentido, empreendidas por Oskar Pfister e Hans Zulliger, na Suíça, no início do século XX, à própria Anna Freud, filha de Freud e ao movimento que se iniciou e se estendeu principalmente na França, nos anos 60. Para Millot, "o conhecimento que a psicanálise provê ao educador the permite apenas avaliar os limites de seu poder...e compreender e desculpar as reações que enfrenta" (Millot, 1987,p.87). Ora, esta também representa, para nós, outra grande lição que carece ser apreendida pelos educadores.

Tentamos dizer algo, neste trabalho, especialmente aos formadores de professores e àqueles que pretendem ocupar esse lugar. Acreditamos que a experiência de cada um dos formadores apresentados, tenha nos ensinado algo diferente e interessante. 
Da experiência da pesquisadora, é possível perceber sua dificuldade em se arriscar num empreendimento novo, mesmo estando diante das necessidades concretas imprimidas pela sua pesquisa. O medo de fracassar está associado e é proporcional ao peso do Ideal-do-eu, construído em sua relação com o discurso do Outro de Malu, da Academia e também da Psicanálise e da Pedagogia. Uma angústia é gerada no conflito entre os Outros, os quais ela não quer decepcionar e o seu desejo genuíno de crescer como pesquisadora e profissional. Sobretudo, e mais importante: sua ação esbarra praticamente o tempo todo na fantasia que ela mantém do Outro como completo.

Mas, a medida em que a análise se desenrola, a pesquisadora descobre que o Outro é barrado, faltante, castrado. A imagem idealizada de Malu, por exemplo, como formadora segura de si, firme e ao mesmo tempo suave, dá lugar a uma figura cheia de conflitos e contradições, que, por sua vez, também se encontra em alguns momentos atada ao saber do Outro, seu orientador. A mesma formadora que, como Outro, inibia a pesquisadora frente ao grupo de professores e frente as suas sugestões de atividades para o curso, se mostrou também como pequeno outro, parceira com quem compartilhava as dificuldades e angústias da tarefa de formar e, ao mesmo tempo, com quem rivalizava, desejando tomar o seu lugar de formadora.

A Academia, enquanto corpo de pesquisadores, mesmo com suas determinações e valores, representa um saber em constante mudança que, por essência, demanda e incorpora sem cessar, conhecimentos novos. A Psicanálise, como já dissemos, também como corpo organizado de saberes, não promete soluções. Aliás, a questão do que a Psicanálise "propõe" no nível de um processo de mudança na Educação e na formação dos seus agentes, estaria na criatividade nos processos tanto de conhecimento quanto de ação pedagógicas. Nesse sentido, nós colocamos na mesma posição do Filloux (1999), quanto às possibilidades que a Psicanálise nos oferece:

...abordagem de problemas que a Pedagogia não coloca jamais; possibilidade de que a leitura do campo pedagógico e educativo, e de que a leitura que o professor faria de si mesmo nesse campo possa 
questioná-lo sobre a prática e colocá-lo na posição de criar.(Filloux,1999,p.38)

Mesmo a técnica analítica, o próprio Freud já dizia que se tratava "apenas de um instrumento que the convinha, mas que talvez outros pudessem se servir de outros instrumentos. Assim, nenhuma regra pode dispensar o analista de assumir a responsabilidade por seu ato à sua maneira" (Chemama,2002,p.168). A preocupação da pesquisadora com o controle da estratégia aplicada ao grupo de professores, de forma análoga à técnica analítica, destoa por completo da essência desta última, porque, estabelecer a livre associação, a escuta flutuante e as intervenções interpretativas, pressupõem um desprendimento, por parte do condutor, de juízos, valores e defesas conscientes e inconscientes. O mesmo se pode dizer em relação aos efeitos do trabalho sobre os aprendizes: um questionamento que se pretende perturbador, não pode prever seu alcance sobre o sujeito. O retorno da professora Zilda com seu problema de sala de aula, é um exemplo de sujeito que enganchou singularmente o significante desejo de saber, veiculado no curso, à sua cadeia prévia de significantes e criando a partir dele um saber para resolver a sua situação.

A Pedagogia é o Outro que, simbolicamente, estaria por detrás da necessidade desse controle. Já falamos exaustivamente sobre as ilusões desse campo no que se refere aos ideais a serem atingidos pela educação. Como um saber que idealiza as atitudes dos educadores, assim como os resultados que se deve atingir com os educandos, foi capaz de produzir um mal-estar na pesquisadora, a ponto de quase inibir sua iniciativa de se aproximar do grupo de professores. O problema da busca desse controle estava na tentativa da formadora de antecipar seu encontro com o real, imaginando previamente como se daria seu contato com o outro.

O grupo de professores, no papel de pequeno outro para a pesquisadora, compromete sua posição de Mestre perante seus aprendizes. A identificação com seu semelhante - principalmente no tocante às queixas - pode promover a aproximação dos sujeitos e inaugurar parcerias para encontrar as soluções dos problemas, mas não foi o caso da pesquisadora. A identificação, em certo momento da discussão, dificultou o estabelecimento da diferenciação necessária entre ela e 
os professores, quando o saber do Mestre poderia tê-los ajudado a procurar suas próprias soluções, ao invés de entrar com eles no circuito de gozo das lamentações.

Outro fato importante dessa análise - senão o mais - é mostrar que a pesquisadora também é castrada, incompleta. A expectativa por um efeito impactante de suas intervenções sobre os professores, não se concretizou, pelo menos da forma como ela esperava. Para aumentar as chances de efetivar sua proposta, ao nosso ver, seria necessária a promoção de sucessivos encontros com os professores, inclusive para fazer com eles o retorno das interpretações realizadas a posteriori.

Com a experiência de Malu, constatamos como a atuação do inconsciente pôde, em alguns momentos, favorecer a situação da formadora ou atrapalhar sua tarefa. O mais interessante foi analisar a mudança da posição subjetiva de Malu em relação ao seu orientador. Inicialmente, "pensando como que o meu orientador gostaria que aquela aula acontecesse", Malu permanece presa ao saber do Outro idealizado. Mas, ao ser "abandonada" por ele, reverte o processo, responsabilizando-se por seus atos ao declarar "vou levar do jeito que eu sei". Mesmo a posição do orientador, é interessante comentá-la sob o ponto de vista das práticas comuns a grande parte dos docentes. É difícil para muitos professores assumirem o papel de orientadores na aprendizagem dos alunos. Na ânsia por deterem o controle do processo, não deixam espaços para os alunos criarem, como é o caso da professora citada por Arruda et al. (2004) que, por não suportar ver seus alunos sofrerem, antecipava seus conflitos cognitivos, não permitindo que eles os enfrentassem.

Por outro lado, mesmo desenvolvendo seu trabalho em clima de parceria, colaboração e troca de experiências com os professores, Malu sentia necessidade, em alguns momentos, de impor sua posição de Mestre. Sabemos que tais posturas não são excludentes, mas o que nos importa é compreender que a dificuldade da formadora em assumir sua autoridade, pode estar justamente no paradoxo do processo identificatório com o pequeno outro, explicitado anteriormente no caso da pesquisadora. 
Da experiência de Nil, aprendemos como o formador se porta diante do desejo. Num sentido favorável, o desejo é mola propulsora que move o formador a superar seus limites como pessoa e profissional. Num outro sentido, o desejo revela sua face narcísica, impelindo Nil a imaginar e agir como se o outro buscasse a satisfação a partir do mesmo objeto que ele, no caso, o conhecimento.

Assim como a pesquisadora e como Malu, Nil também apresenta dificuldades em assumir a autoridade de Mestre no momento necessário. No caso de Nil, acreditamos que sua dificuldade esteja ligada, em parte, ao processo identificatório com os professores - já que o formador e alguns dos professores do grupo foram, outrora, parceiros em cursos de formação. No entanto, parece que o desejo narcísico de Nil atua com mais força sobre os professores, levando-os a realizar tarefas pouco significativas para eles e às vezes, também não conseguindo descobrir e sustentar suas reais dificuldades.

Ronaldo é o formador que apresenta um tempo de experiência com formação de professores um pouco maior do que a pesquisadora, Malu e Nil. Em comparação com esses formadores, Ronaldo parece avançar como formador em relação a alguns aspectos de sua posição subjetiva. Não encontramos, por exemplo, Ronaldo se referindo ou submetendo seu desejo a algum Outro, em seus relatos de prática. Percebemos Ronaldo bastante confiante e autônomo em relação às decisões e às condutas que adota no exercício das suas atividades como formador. Além disso, Ronaldo também aposta e faz questão de construir relações interpessoais saudáveis com os professores, como modo de ganhar a confiança necessária dos grupos e poder realizar um trabalho razoavelmente harmônico com sua proposta.

No entanto, sua forma de obter a harmonia e conseqüentemente, a satisfação desejada em seu trabalho esbarra, para nós, em duas questões, ainda não resolvidas para Ronaldo. Primeiro, sua identidade como mestre, como autoridade no saber, ainda se encontra abalada pelo sentimento de culpa por, ora se julgar numa condição superior, ora inferior aos professores. Em segundo lugar, o formador goza em seu circuito de repetição, a cada curso que inicia e termina, porque tem a ilusão de que da próxima vez vai ser diferente. Mas parece que 
Ronaldo não percebeu que o real dos sujeitos com quem ele lida não muda, ao contrário, o que deve mudar é o seu modo de lidar com esse real.

O que Ronaldo percebe bem e o incomoda, é o real do sintoma que os professores trazem aos cursos: as queixas, as lamentações, o desânimo, a falta de responsabilidade pela sua situação. O sintoma, para a psicanálise, fala a verdade do sujeito. "É um lugar que contém uma verdade para o sujeito, e, dependendo da interpretação que ele Ihe der, procurará um médico ou um analista, ou ainda um padre ou um pai-de-santo" (Quinet, 2000, p.122).

O que os formadores podem fazer em relação ao sintoma dos professores? Ainda, estaria o formador para o médico, o analista ou o padre? Depende de como os professores interpretam seus sintomas: se eles acreditam que poderão se livrar do sintoma por meio da ciência ou da fé, poderão procurar pelo médico ou pelo padre. Depende também da opção do formador e de como ele se posiciona em relação ao seu próprio sintoma: se ele acredita que pode lidar com "fórmulas" ou com "milagres", poderá trabalhar como médico, oferecendo "receitas" ou como padre, ofertando preces e deixando que as coisas se resolvam pela mão de Deus.

Para nós, a melhor opção seria o formador trabalhar ao lado do analista. Pois, que nem um nem outro deverão livrar o sujeito do seu sintoma, nem tampouco farão grandes revelações sobre sua verdade, porque, para a psicanálise, o sintoma é um "semi-dizer" e a verdade, um enigma nunca totalmente desvelado. $O$ que ambos podem fazer é tomar distância do sintoma, levar os sujeitos - professor e paciente a aprenderem um jeito de lidar com ele na forma, na enunciação, ou seja, a criarem o que Lacan chama de estilo.

A experiente formadora Jerusa, por exemplo, nos parece operar a partir de um estilo próprio, um estilo que faz a diferença entre a sua postura e a postura dos demais formadores. Ela nos mostra que a diferença entre "exercer a função' e "assumir o lugar" de formador não está apenas no conhecimento acumulado e no tempo de experiência. Mas a autorização que só a ela caberia dar a si mesma, parece vir da capacidade que ela desenvolveu de fazer uma experiência de si, de lidar com sua própria subjetividade. 
Seu alto grau de satisfação pessoal e aparente ausência de conflitos, contrasta com a freqüência das queixas e tensões, com a alternância dos estados de satisfação e insatisfação com prática, que percebemos no grupo dos formadores iniciantes. Jerusa parece ultrapassar os limiares aos quais os outros formadores ainda se mantêm aquém e, de certa forma, alienados. Enquanto os outros formadores ainda se encontram submetidos ou identificados no Outro/outro, Jerusa aprendeu a dar ao Outro/outro o que é do Outro/outro.

Jerusa consegue exercer sua mestria de uma forma mais plena do que os outros formadores porque, aparentemente, não há para ela um grande Outro a quem deva servir. Parece que ela é o Outro para seus professores; o Outro da demanda, o Outro do desejo. O ditado diz "o hábito faz o monge" mas, nas palavras de Miranda, uma analista, "é preciso ser monge para poder carregar o hábito".

Entretanto, a entrevista com Jerusa nos deixou uma dúvida. Seu relato sinalizava e oferecia vários indícios de que em sua relação com os professores, ela conseguia assumir diferentes posições: às vezes se colocava como Mestre, convidando os professores a investir no trabalho de planejamento, ou como Juiz, marcando as falhas em suas conclusões; outras vezes, ela atuava como Histérica, questionando os professores e desafiando-os a atuar de forma mais criativa, ou como Analista, se surpreendendo com as iniciativas originais dos professores e sustentando-as, mesmo sem ter certeza sobre os resultados. No entanto, durante a entrevista ela se colocou e foi por nós aceita unicamente como Mestre, quando ambas, formadora e pesquisadora, gozando dessa relação, perderam a chance de avançar na produção de um novo conhecimento sobre a formação de professores.

Consideramos que a prática de uma reflexão questionadora, que pretenda investigar mais profundamente as crenças e teorias do sujeito, deva ter um caráter perturbador. Esse tipo de reflexão mais profunda ocorre quando o sujeito se surpreende com suas próprias revelações, ou seja, quando "de repente ele se dá conta". Tendo em vista nossas análises e nossas conclusões acerca das 
experiências dos formadores, do papel do formador e dos reflexos das suas posições subjetivas na formação de professores em serviço, nossa proposição para um modelo teórico de formação continuada poderia considerar os seguintes pressupostos:

1-É necessário investigar histórias passadas onde estarão contidas representações que o sujeito construiu ao longo dela. No caso dos professores, histórias que remetem o sujeito aos tempos em que era estudante, podem trazer elementos que incorporou a partir de seus modelos de professor, de aluno, de escola, de aprendizagem e até de colegas. Esses modelos podem trazer crenças que, na atualidade, perderam sua validade. Como em análise, muitas das representações que construímos a partir de nossas referências da infância, como as experiências em família que incluem hábitos domésticos, continuam a ser atualizadas pelo nosso inconsciente em práticas que não fazem mais sentido quando ficamos adultos. Ao contrário, outras representações que trazemos em nosso inconsciente podem nos impulsionar para uma evolução saudável e trazer efeitos de sucesso e bem-estar em nossa vida atual.

2-Embora se pretenda um questionamento sobre o sujeito da prática, a utilização de técnicas análogas às de análise - livre associação, escuta flutuante e intervenções interpretativas - não está dissociada da discussão sobre das práticas dos sujeitos. Durante o desenvolvimento das atividades, surgem os problemas e os impasses que se constituirão em material em pauta para ser analisado. As histórias passadas dos sujeitos complementam e ajudam na compreensão das suas ações e reflexões atuais.

3-É conveniente que se faça um registro das falas dos sujeitos de modo a auxiliar sua interpretação a posteriori. O fornecimento de um feedback aos professores, relativamente a essas interpretações, além de fomentar o autoquestionamento, servirá para elevar o nível da reflexão, trazendo constantemente novos dados para interpretação.

4-É importante a instauração de um clima de confiança entre os professores e os formadores, que favoreça o afloramento da subjetividade dos sujeitos. A utilização de recursos como exibição de vídeos, dinâmicas de grupo e a leitura de 
textos que tratem da conexão entre psicanálise e educação, podem estimular o surgimento e o aprofundamento de novas questões.

Particularmente, defendemos que o formador e também o professor, sejam introduzidos no universo da psicanálise, para que não ajam somente baseados em sua intuição, mas com o respaldo de um campo que inclui teoria e prática não somente restritas à clínica, e que comporta um saber que cada vez mais tem se revelado promissor em seu diálogo com a educação. Como diz Kupfer, "a chuva fará germinar a semente se o solo for fértil - o saber da psicanálise poderá ser operativo para um educador se ele puder se apropriar desse saber" (2000, p.118).

Nesse sentido, esperamos, sinceramente, que muitos formadores e professores venham a se apropriar deste trabalho, como fonte de inspiração e incentivo ao tipo de questionamento que propomos desde o início. E, quiçá, façam parte daqueles que já sabem porque a descoberta freudiana "perturba a paz do mundo e o sono dos homens". 


\section{REFERÊNCIAS BIBLIOGRÁFICAS}

ALARCÃO, I. Reflexão crítica sobre o pensamento de D. Schön e os programas de formação de professores. In: (org). Formação reflexiva de professores: estratégias de supervisão. Porto: Porto Editora, 1996, p.11-39.

ALBERTI, S.; POLLO, V. (org.) Psicanálise, Educação: referências em Freud e Lacan. I Jornada do Núcleo de Pesquisa em Psicanálise com Crianças. Escola Brasileira de Psicanálise. Rio de Janeiro, 1996.

ALTARUGIO, M.H. "Este curso não se adapta à minha realidade": os conflitos de um grupo de professores de química em formação continuada. Dissertação (Mestrado em Ensino de Ciências) - Faculdade de Educação, Instituto de Física, Instituto de Química da Universidade de São Paulo, 2002.

AMARAL, M. J.; MOREIRA, M.A .; RIBEIRO, D. O papel do supervisor no desenvolvimento do professor reflexivo: estratégias de supervisão. In: Alarcão, I. (org). Formação reflexiva de professores: estratégias de supervisão. Porto: Porto Editora, 1996, p.91-119.

AQUINO, J.G; MUSSI, M.C. As vicissitudes da formação docente em serviço: proposta reflexiva em debate. Educação e Pesquisa, São Paulo, v.27, n.2, p221227,,jul/dez.2001.

ARRUDA, S. et al. Da aprendizagem significativa à aprendizagem satisfatória na Educação em Ciências. Caderno Brasileiro de Ensino de Física, Florianópolis, v. 21, n. 2, p. 194-223, 2004.

BACHA, M.N. A arte de formar: o feminino, o infantil e o epistemológico. Petrópolis, R. J.: Vozes,2002. 
BELINTANE, C. "Instante complexo da vacilação na sala de aula". Mimeografado. BRASIL, Ministério da Educação e do Desporto/ Secretaria de Educação Média e Tecnológica. Parâmetros Curriculares Nacionais. Bases Legais. Brasília:1998. Disponível em: http://www.mec.gov.br. Acesso em 2000.

CABRAL, T.C.B. Educação e psicanálise: buscando outros paradigmas. Pesquisas em Ensino de Ciências, Bauru, n.3,p. 32-45, 1996.

CELANI, M.A.A. A educação continuada do professor. Ciência e Cultura, 40(2),p.158-163, 1988.

CHARLOT, B. Da relação com o saber. Elementos para uma teoria. Porto Alegre: Artmed Editora, 2000.

CHARLOT, B. Práticas linguageiras e fracasso escolar. Estilos da Clínica, v.V, n.9, $2^{\circ}$.sem, 2000.

CHEMAMA, R. (org). Dicionário de Psicanálise. 2.ed. Larousse. Porto Alegre: Artmed Editora, 2002.

CIFALI, M. Conduta Clínica, formação e escrita. In: Paquay, L; Perrenoud, P; Altet, M; Chalier, É. (orgs). Formando professores profissionais: quais estratégias? Quais competências? Porto Alegre: Artmed Editora, 2.ed. 2001, p. 103-117.

CONTRERAS, J. La autonomia del profesorado. Madri: Morata, 1997.

COPPELO LEVY, M.I..; SANMARTí PUIG, N. Fundamentos de um modelo de formación permanente del profesorado de ciencias centrado em la reflexión dialógica sobre lãs concepciones y lãs prácticas. Enseñanza de las ciencias, 19(2), p.269-283, 2001.

DEWEY, J. Como pensamos: como se relaciona o pensamento reflexivo com o processo educativo: uma reexposição. 3.ed. São Paulo: Companhia Editora Nacional, 1959.

FILLOUX, J.C. Psicanálise e Pedagogia ou: sobre considerar o inconsciente no campo pedagógico. A Psicanálise e os Impasses da Educação. Anais do I Colóquio do Lugar de Vida/Lepsi. São Paulo: Editora USP, 1999, p.9-42. 
FINK, B. O sujeito lacaniano: entre a linguagem e o gozo. Rio de Janeiro: Jorge Zahar Editor, 1998.

FORBES, J. Palavras e corpos na segunda clínica de Lacan. Seminário I. Universidade de São Paulo, 1999.

. Seminário IV. Universidade de São Paulo, 1999.

. Seminário V. Universidade de São Paulo, 1999.

. Seminário VI. Universidade de São Paulo, 1999.

FREUD, S. (1912) Recomendações aos Médicos que Exercem a Psicanálise. Edição Eletrônica Brasileira das Obras Psicológicas Completas de Sigmund Freud. Rio de Janeiro: Imago, vol XII, CD-ROM. . (1921) Psicologia de grupo e análise do ego, EEB, XVIII.

FRANZONI, M. Investigando os convites docentes na formação inicial de professores de física e biologia. In: IV Encontro Nacional de Pesquisa em Educação em Ciências, Bauru. Atas IV ENPEC, 2003. CD-ROM.

GARCIA, C. M. A formação de professores: novas perspectivas baseadas na investigação sobre o pensamento do professor. In: Nóvoa A. Os professores e sua formação. Lisboa: Dom Quixote, 1992, p. 53-76.

Pesquisa sobre a formação de professores. Revista Brasileira de Educação, n.9, p.51-75,set/out/nov/dez, 1998.

GIORDAN, M. Educação em química e multimídia. Química Nova na Escola, n.6, nov, 1997.

GRANT, W.H. O ensino da psicanálise: o outro lado da transmissão. Doxa: Revista Paulista de Psicologia e Educação, n.3,p.31-45, set/dez, 1995.

GUTIERRA, B.C.C. Adolescência, Psicanálise e Educação: o mestre "possível" de adolescentes. São Paulo: Avercamp, 2003.

KUPFER, M.C. Educação para o futuro. Psicanálise e educação. São Paulo: Editora Escuta, 2000. 
KUPFER, M.C. Freud e a Educação: o mestre do impossível. São Paulo: Editora Scipione, 2001.

LACAN, J. O seminário, livro 1: Os escritos técnicos de Freud (1953-54). Rio de Janeiro: Jorge Zahar, 1979.

. O seminário, livro 2: O eu na teoria de Freud e na técnica da psicanálise. (1954-55). Rio de Janeiro: Jorge Zahar, 1985. . O seminário, livro 17: O avesso da psicanálise (1969-70). Rio de Janeiro: Jorge Zahar, 1992. . O seminário, livro 20: Mais ainda (1972-73). Rio de Janeiro: Jorge Zahar, 1985.

LAJONQUIĖRE, L. de. Infância e Ilusão (Psico)Pedagógica. Petrópolis: Editora Vozes,1999.

LOPES, E.M.T. O professor é um mestre? In: Mrech, L.M. (org) O impacto da psicanálise na educação. São Paulo: Avercamp Editora, 2005, p.71-92.

MACHADO, A.H., MOURA, A.L.A. Concepções sobre o papel da linguagem no processo de elaboração conceitual em química. Química Nova na Escola, n.2, p.2730, nov, 1995.

MACHADO, A.H. Pensando e falando sobre fenômenos químicos. Química Nova na Escola, n.12, p.38-42, nov, 2000.

MENDONÇA FILHO, J.B. de. Ensinar: do mal-entendido ao inesperado da transmissão. In: LOPES, E.M.T. (org) A psicanálise escuta a educação. Belo Horizonte: Autêntica Editora, 2001, p.71-106.

MILLER, J-A . A erótica do tempo. RJ: Latusa, 2000.

MILLOT, C. Freud Antipedagogo. Rio de Janeiro: Jorge Zahar Editor, 1987.

MIRANDA, C.L.S. Identidade: síntese das múltiplas identificações. Taubaté: Cabral Editora Universitária, 1998.

MONTEIRO, E. A. Sobre uma especificidade do ensino da psicanálise na universidade: a formação de educadores. Tese (Doutorado em Educação) Faculdade de Educação da Universidade de São Paulo, 2005. 
MORTIMER, E.F. Uma agenda para a pesquisa em educação em ciências. Revista Brasileira de Pesquisa em Educação em Ciências, 2(1)25-35, 2002.

.; Machado A.H. A linguagem numa aula de ciências. Presença Pedagógica, v.2, n. 11, p.49-57, set/out, 1996.

MRECH, L. M. Psicanálise e Educação: novos operadores de leitura. São Paulo: Pioneira Editora, 1999.

- O mercado de saber, o real da educação e dos educadores e a escola como possibilidade. Tese (Livre Docência) - Faculdade de Educação da Universidade de São Paulo, 2001.

. O impacto do terceiro ensino de Lacan: novas contribuições para algumas articulações possíveis entre psicanálise e educação. In:

(org). O impacto da psicanálise na educação. São Paulo: Avercamp Editora, 2005. NASIO, J-D. Cinco lições sobre a teoria de Jacques-Lacan. Rio de Janeiro: Jorge Zahar Editor, 1993.

Lições sobre os 7 conceitos cruciais da psicanálise. Rio de Janeiro: Jorge Zahar Editor, 1995.

Como trabalha um psicanalista? Rio de Janeiro: Jorge Zahar Editor, 1999.

PACCA, J.L.de A ; VILLANI, A . Conhecimento e saber do professor de física: uma interpretação psicanalítica. Atas XXIII Reunião Anual da ANPED, 2000, p.13.CDROM.

PAIVA, E.V. de. A formação do professor crítico-reflexivo. In: . (org). Pesquisando a formação de professores. Rio de Janeiro: DP \& A Editora, 2003,p.47-65.

PEREIRA, M.R. Subversão docente: ou para além da 'realidade do aluno'. In: Mrech, L.M. (org) O impacto da psicanálise na educação. São Paulo: Avercamp Editora, 2005, p.93-116.

PÉREZ GÓMEZ, A .O pensamento prático do professor: a formação do professor como profissional reflexivo. In: Nóvoa A. Os professores e sua formação. Lisboa: Dom Quixote, 1992, p. 95-114.

PERRENOUD,P. O trabalho sobre o habitus na formação de professores: análise das práticas e tomada de consciência. In: Paquay, L; Perrenoud, P; Altet, M; 
Chalier, É. (orgs). Formando professores profissionais: quais estratégias? Quais competências? Porto Alegre: Artmed Editora, 2.ed.. 2001, p. 161-184.

POULICHET, S. LE. O conceito de narcisismo. In: NASIO, J-D. Lições sobre os 7 conceitos cruciais da psicanálise. Rio de Janeiro: Jorge Zahar Editor, 1995, p.47-67.

QUINET, A . A descoberta do inconsciente: do desejo ao sintoma. Rio de Janeiro: Jorge Zahar Editor, 2000.

SCHÖN, D.A . Formar professores reflexivos. In: Nóvoa A. Os professores e sua formação. Lisboa: Dom Quixote, 1992, p. 79-92.

SCHNETZLER, R.P.; ARAGÃO, R.M.R. Importância, sentido e contribuições de pesquisas para o ensino de química. Química Nova na Escola, n.1, p.27-31, mai, 1995.

SILVA, L.H. de ARRUDA; SCHNETZLER, R.P. Buscando o caminho do meio: a "sala de espelhos" na construção de parcerias entre professores e formadores de professores de ciências. Ciência \& Educação, v.6, n.1,p.43-53, 2000

SOUZA, M.C.C.C de. Os professores escutaram a Psicanálise - mas quais foram os efeitos? In: MRECH, L. M.(org). O impacto da psicanálise na educação. São Paulo: Avercamp Editora, 2005, p.129-141.

SUDAN, D.C. Saberes em construção de uma Professora que pesquisa sua própria prática. Dissertação (Mestrado em Educação) - Departamento de Educação da UFSCar, 2005.

VILLANI, A. et al. Contribuições da Psicanálise para uma Metodologia de Pesquisa em Educação em Ciências. In: SANTOS, F. M. T. dos; GRECA, I. M. (Org.). A Pesquisa em Ensino de Ciências no Brasil e suas metodologias. Porto Alegre, 2006, p. 323-390.

VILLANI, A. , BAROLLI, E. Os discursos do professor e o ensino de ciências. Proposições. Campinas, v.17, n.1, p.5-25, 2006.

ZEICHNER, K. Novos caminhos para o practicum: uma perspectiva para os anos 90. In: Nóvoa A. Os professores e sua formação. Lisboa: Dom Quixote, 1992, p. 117-138. 